WSRC-STI-2007-00004, Rev. 2

KEY WORDS: Performance

Assessment

Transfer Factors

Human Health

\title{
BASELINE PARAMETER UPDATE FOR HUMAN HEALTH INPUT AND TRANSFER FACTORS FOR RADIOLOGICAL PERFORMANCE ASSESSMENTS AT THE SAVANNAH RIVER SITE
}

\author{
Patricia L. Lee, SRNL \\ Timothy W. Coffield, SRIP
}

August 13, 2007

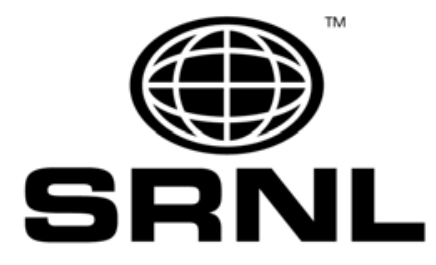

Savannah River National Laboratory Washington Savannah River Company

Savannah River Site Aiken, SC 29808

PREPARED FOR THE U.S. DEPARTMENT OF ENERGY UNDER CONTRACT NO. DE-AC09-96SR18500 


\section{DISCLAIMER}

This report was prepared by Washington Savannah River Company LLC for the United States Department of Energy under Contract No. DE-AC09-96SR18500 and is an account of work performed under that contract. Reference herein to any specific commercial product, process, or service by trademark, name, manufacturer, or otherwise does not necessarily constitute or imply endorsement, recommendation, or favoring of same by Washington Savannah River Company LLC or by the United States Government or any agency thereof. 


\section{REVIEWS AND APPROVALS}

\section{Authors}

Patricia L. Lee, Environmental Analysis Section

Date

Timothy W. Coffield, SRIP Site Regulatory Integration and Planning

Date

\section{Reviews/Approvals}

G. T. Jannik, Environmental Analysis Section

Date

Mark H. Layton, SRIP Site Regulatory Integration and Planning

Date

Elmer Wilhite, Environmental and Chemical Process Technology

Date

Thomas C. Robinson, Mgr SRIP Regulatory Documentation

Date

William E. Stevens, Mgr Environmental and Chemical Process Technology

Date 
TABLE OF CONTENTS

LIST OF TABLES...................................................................................................................................... VI

LIST OF ACRONYMS AND ABBREVIATIONS ........................................................................

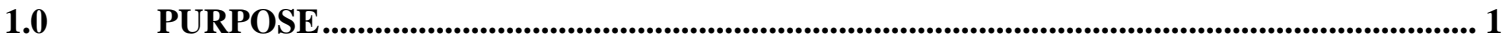

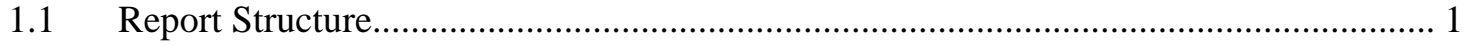

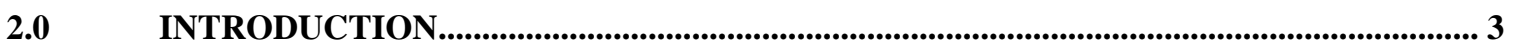

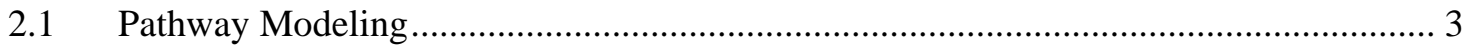

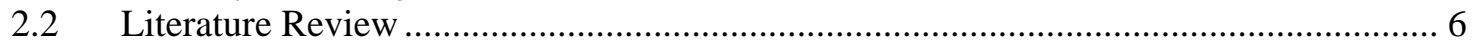

P.0 PHSICAL HUMAN HEALTH EXPOSURE PARAMETERS ......................................... 9

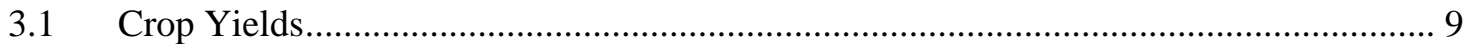

3.2 Fraction of Foodstuff Intake from Garden ...................................................... 9

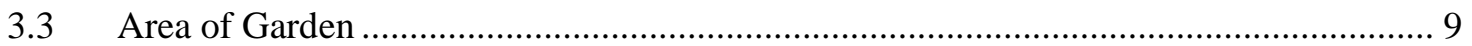

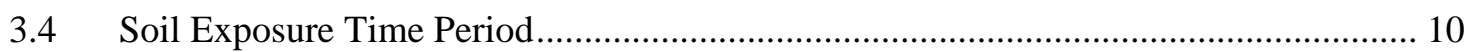

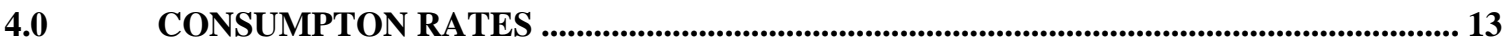

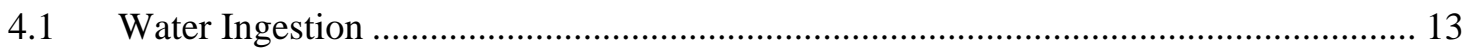

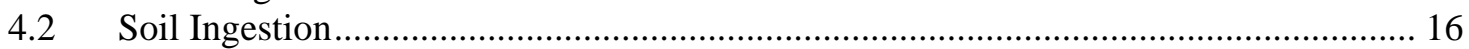

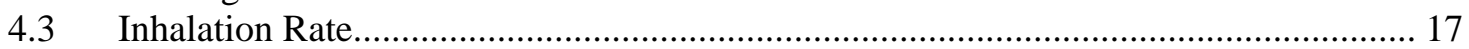

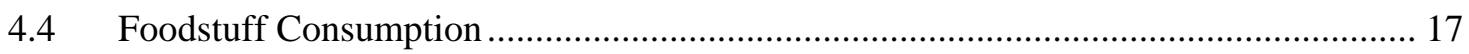

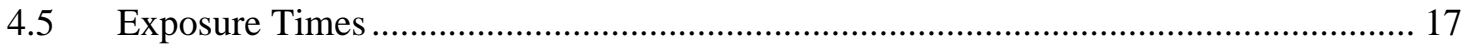

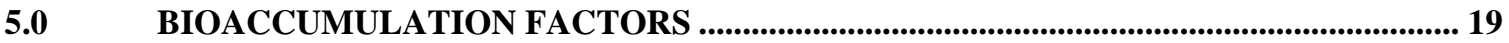

5.1 Soil-to-Vegetable Transfer Factors ........................................................... 19

5.2 Feed-to-Milk Transfer Factors........................................................................ 23

Feed-to-Meat Transfer Factors ...................................................................... 23

5.4 Water-to-Fish Accumulation ....................................................................... 24

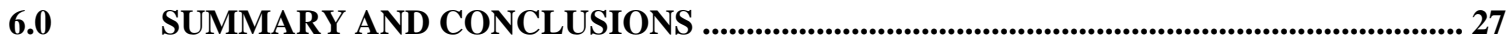

6.1 Summary of Updates .......................................................................... 27

6.2 Potential Impact on Performance Assessments ............................................... 27

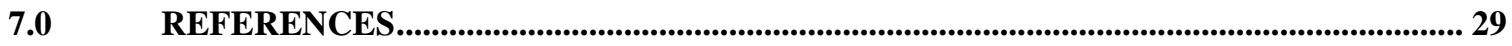

APPENDIX A. Physical Parameters and Consumption Rates Considered........................... 33

APPENDIX B. Comprehensive Bioaccumulation Factors ................................................... 37 


\section{LIST OF TABLES}

Table 2-1. Hierarchy of Reference Used for Bioaccumulation Sources ................................... 8

Table 3-1. $\quad$ Updated Crop Exposure Times and Productivity ................................................. 11

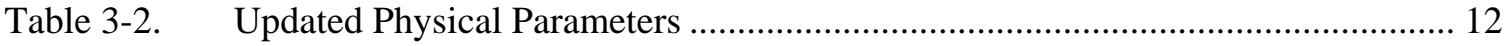

Table 4-1. $\quad$ Updated Individual Exposure Times and Consumption Rates ............................. 14

Table 5-1 Regional Relative Importance of Vegetables from ORNL-5786 ............................ 20

Table 5-2. Site-specific Regional Conversion Factors for Soil-to-Vegetable Transfer Factors

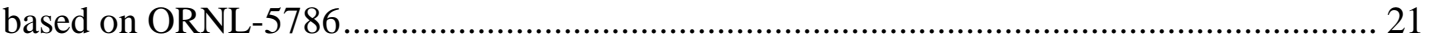

Table 5-3. $\quad$ Updated Soil-to-Vegetable Transfer Factors for Select Elements.......................... 22

Table 5-4. $\quad$ Updated Feed-to-Milk Transfer Factors (d/L) for Select Elements....................... 23

Table 5-5. Updated Feed-to-Meat Transfer Factors (d/kg) for Select Elements..................... 24

Table 5-6. $\quad$ Updated Water-to-Fish Accumulation Factors (L/kg) for Select Elements .......... 25

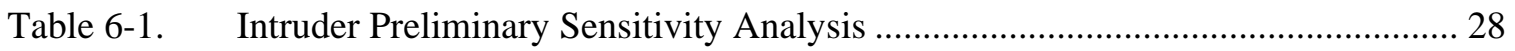

Table 6-2. All Pathways Preliminary Sensitivity Analysis .................................................. 28

Table A- 1. Crop Exposure Times and Productivity from the Other Sources ......................... 33

Table A- 2. Physical Parameters from the Other Sources ..................................................... 34

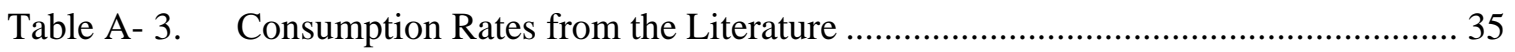

Table B-1. Comprehensive Updated Soil-to-Vegetable Transfer Factors ................................ 37

Table B- 2. Comprehensive Updated Feed-to-Milk Transfer Factors (d/L).......................... 40

Table B- 3. Comprehensive Updated Feed-to-Meat Bioaccumulation Factors (d/kg) ............ 43

Table B- 4. Comprehensive Updated Water-to-Fish Bioaccumulation Factors (L/kg)........... 46

Table B- 5. Soil-to-Vegetable Transfer Factors from Other Sources ….................................. 49

Table B- 6. Feed-to-Milk Transfer Factors (d/L) from Other Sources ..................................... 53

Table B- 7. Feed-to-Meat Bioaccumulation Factors (d/kg) from Other Sources ..................... 57

Table B- 8. Water-to-Fish Bioaccumulation Factors (L/kg) from Other Sources .................... 61

Table B- 9. Bioaccumulation Factors from Other DOE Facilities ........................................... 65 


\section{LIST OF ACRONYMS AND ABBREVIATIONS}

\section{ACRONYMS}

$\begin{array}{ll}\text { CDC } & \text { Centers for Disease Control and Prevention } \\ \text { CFR } & \text { Code of Federal Regulations } \\ \text { CSFII } & \text { Continuing Survey of Food Intakes by Individuals } \\ \text { DOE } & \text { Department of Energy } \\ \text { EPA } & \text { Environmental Protection Agency } \\ \text { EFH } & \text { Exposure Factors Handbook } \\ \text { GSA } & \text { General Separations Area } \\ \text { IAEA } & \text { International Atomic Energy Agency } \\ \text { ICRP } & \text { International Commission on Radiological Protection } \\ \text { HLW } & \text { High Level Waste } \\ \text { LLW } & \text { Low Level Waste } \\ \text { MEI } & \text { Maximum Exposed Individual } \\ \text { NCRP } & \text { National Council on Radiation Protection and Measurements } \\ \text { NDAA } & \text { National Defense Authorization Act } \\ \text { NESHAP } & \text { National Emissions Standards for Hazardous Air Pollutants } \\ \text { NRC } & \text { Nuclear Regulatory Commission } \\ \text { PA } & \text { Performance Assessment } \\ \text { RESRAD } & \text { RESidual RADioactivity } \\ \text { SRS } & \text { Savannah River Site } \\ \text { PNNL } & \text { Pacific Northwest National Laboratory } \\ \text { ORNL } & \text { Oak Ridge National Laboratory } \\ \text { USA } & \text { United States of America } \\ \text { USDA } & \text { United States Department of Agriculture }\end{array}$

\section{ABBREVIATIONS}

$\begin{array}{ll}\mathrm{Bq} & \text { becquerel } \\ \mathrm{cm} & \text { centimeter } \\ \mathrm{Ci} & \text { curie } \\ \mathrm{d} & \text { day } \\ \rho & \text { bulk density } \\ \mathrm{hr} & \text { hour (s) } \\ \mathrm{kg} & \text { kilogram } \\ \mathrm{L} & \text { liter } \\ \mathrm{m} & \text { meter } \\ \mathrm{mg} & \text { milligram } \\ \mathrm{mL} & \text { milliliter } \\ \mathrm{p} & \text { pico } \\ \mathrm{Sv} & \text { sievert } \\ \mathrm{yr} & \text { year }\end{array}$




\subsection{PURPOSE}

The purpose of this report is to update parameters utilized in Human Health Exposure calculations and Bioaccumulation Transfer Factors utilized at SRS for Performance Assessment modeling. The reason for the update is to utilize more recent information issued, validate information currently used and correct minor inconsistencies between modeling efforts performed in SRS contiguous areas of the heavy industrialized central site usage areas called the General Separations Area (GSA). SRS parameters utilized were compared to a number of other DOE facilities and generic national/global references to establish relevance of the parameters selected and/or verify the regional differences of the southeast USA. The parameters selected were specifically chosen to be expected values along with identifying a range for these values versus the overly conservative specification of parameters for estimating an annual dose to the maximum exposed individual (MEI).

The end uses are to establish a standardized source for these parameters that is up to date with existing data and maintain it via review of any future issued national references to evaluate the need for changes as new information is released. These reviews are to be added to this document by revision.

\subsection{Report Structure}

Section 2.0 provides background information on the dose estimates for performance assessments at the Savannah River Site. The remaining sections of this report describe physical human health input parameters (Section 3.0), consumption rates (Section 4.0) and element-specific transfer factors (Section 5.0) for these analyses and discusses differences in updates to these factors. 
THIS PAGE INTENTIONALLY LEFT BLANK 


\subsection{INTRODUCTION}

The Savannah River Site (SRS) generates Performance Assessments in order to demonstrate compliance with environmental performance objectives including annual radiological doses and groundwater concentrations. Performance Assessment modeling accounts for many aspects of environmental transport modeling including water infiltration through a closure cap and waste form, contaminant releases to the infiltrating water and contaminant transport through the aquifer system(s).

Once groundwater contaminant concentrations are calculated at any location of interest, the contaminant concentrations may need to be converted to an annual radiological dose. There are two categories of doses: dose to a member of the public who is assumed to live or perform activities outside of the controlled buffer zone around a disposal site and dose to an intruder who is assumed to intrude within the disposal site and perform activities. While these are two different types of activities, similar exposure pathways may be used for both categories of dose calculations. The pathways may not require any additional calculations beyond the groundwater contaminant concentrations as in the case of groundwater ingestion. Other pathways will require several layers of calculations as in the case of milk ingestion in which the groundwater contaminant concentrations must be used to calculate fodder contaminant concentrations due to irrigation by contaminated groundwater and transfer of contaminants to the milk from the contaminated fodder ingestion. These calculations use parameters referred to as bioaccumulation factors to calculate contaminant concentrations via a variety of environmental mechanisms.

Once contaminant concentrations are known in the various environmental media, human consumption of the environmental media can be used to calculate annual radiological doses based on the use of consumption factors. These consumption factors include items such as the amount of groundwater ingested in a day or amount of beef eaten in a year. The assessment of groundwater transport and contaminant concentrations, bioaccumulation factors for environmental media contaminant concentrations and human consumption factors allow the determination of annual radiological doses for comparison to performance objectives.

The values given for the parameters are usually given as 'expected' values together with an observed range rather than values for a maximum exposed individual (MEI) calculation.

A similar calculation path is performed for airborne releases of contaminants into the air and then their disposition on the soil and plant surfaces. Any significant contribution from this pathway may be added to the groundwater dose calculations.

This report considers parameters and factors used in the air and waterborne pathways associated with the All Pathways and Inadvertent Intruder Analyses for radiological performance assessments at SRS.

\subsection{Pathway Modeling}

Dose modeling is performed to estimate radiological dose to human receptors in the all-pathways (public release) analysis, the inadvertent intruder analysis and the air pathway analysis.

The all pathways, inadvertent intruder, and air pathway analyses require the use of physical parameters, pathway-specific usage parameters, and bioaccumulation factors. This report provides brief descriptions of these parameters and factors, their current use, and provides recommendations for updates recommending the use of site-specific values when available. If 
site-specific values are not available then the recommendations use the most recent regional and global values available. Where available, value ranges are provided for sensitivity and uncertainty analyses. Value ranges are based on those provided in the referenced literature from the hierarchy and the value ranges used at other DOE facilities.

\subsubsection{All Pathways Modeling}

The all-pathways dose methodology in the application described in Koffman (2006a) is based on the methodology presented in (NRC 1977). This application calculates the impacts from transport of radionuclides from disposed waste in groundwater and facilitates calculation of disposal limits, based on an assumed unit concentration in groundwater as well as calculation of total dose from all radionuclides disposed if a known or projected inventory at closure is available.

Annual dose to a member of the public (all-pathways dose) at SRS is estimated for various exposure pathways. Brief description of exposure scenarios and the associated potential exposure pathways are as follows.

In an all pathways groundwater well dose analysis, a member of the public is assumed to use water from a well for domestic purposes and assumed to be exposed through the following pathways:

- Direct ingestion of well water

- Ingestion of milk and meat from livestock (e.g., dairy and beef cattle) that drink well water

- Ingestion of vegetables grown in garden soil irrigated with well water

- Ingestion of milk and meat from livestock (e.g., dairy and beef cattle) that eat fodder from pasture irrigated with well water.

Secondary and indirect pathways that are expected to contribute relatively minor doses when compared to direct pathways (such as ingestion of milk and meat) include:

- Inhalation of well water used for irrigation

- Ingestion and inhalation of well water while showering

- Inhalation of dust from the soil that was irrigated with well water

- Ingestion of soil that was irrigated with well water

- Direct radiation exposure from radionuclides deposited on the soil that was irrigated with well water.

In an all pathways surface water dose analyses, a member of the public is assumed to use water from the closest surface water for domestic and recreational purposes. Dose due to domestic use of surface water is assumed to occur through the following exposure pathways:

- Ingestion of milk and meat from livestock (e.g., dairy and beef cattle) that drink surface water

- Ingestion of vegetables grown in garden soil irrigated with surface water

- Ingestion of milk and meat from livestock (e.g., dairy and beef cattle) that eat fodder from pasture irrigated with surface water

Dose from recreational use of contaminated surface water is assumed to occur through the following pathways:

- Direct irradiation during recreational activities (e.g., swimming, fishing) from surface water 
- Dermal contact with surface water during recreational activities (e.g., swimming, fishing)

- Incidental ingestion and inhalation of surface water during recreational activities

- Ingestion of fish from the surface water

Secondary and indirect pathways that are expected to contribute relatively minor doses when compared to direct pathways such as ingestion of milk and meat include:

- Inhalation of surface water used for irrigation

- Inhalation of dust from the soil that was irrigated with surface water

- Inhalation of gaseous radionuclides released from the soil that was irrigated with surface water

- Ingestion of soil that was irrigated with surface water

- Direct radiation exposure from radionuclides deposited on the soil that was irrigated with surface water

\subsubsection{Inadvertent Intruder Modeling}

Intruder analysis estimates are performed to determine radionuclide disposal limits that would bound the impacts on hypothetical individuals assumed to inadvertently access the disposal site. Equations used to estimate dose in this application are documented in Koffman (2006b).

Potential exposure scenarios for estimating annual does to an inadvertent intruder include the acute intruder-drilling scenario, acute intruder-construction scenario, acute intruder-discovery scenario, chronic intruder agricultural (post-drilling) scenario, chronic intruder-resident scenario, and the biointrusion scenario. Brief descriptions of exposure scenarios and the associated potential exposure pathways are as follows.

The Acute Intruder-Drilling Scenario assumes the short-term exposure of a hypothetical intruder to drill cuttings from a borehole penetrating the waste disposal site. This scenario involves wastes buried below the depth of typical construction excavations. The acute drilling scenario assumes that an inadvertent intruder drills a well into ancillary equipment, in this case a transfer line and is exposed to contaminated drill cuttings spread over the ground and contaminated airborne dust.

The exposure pathways for this acute drilling scenario include:

- Inhalation of resuspended drill cuttings

- External exposure to the ground source

- Inadvertent soil ingestion

The Chronic Intruder Agricultural (Post-Drilling) Scenario is an extension of the acute intruder drilling scenario. It is assumed in this scenario that an intruder lives in a building near the well drilled as part of the intruder-drilling scenario and engages in agricultural activities on the contaminated site. The soil is assumed to be contaminated by both drill cuttings and contaminated irrigation water.

The intruder is exposed to:

- Direct ingestion of well water

- Ingestion and inhalation of well water while showering

- Ingestion of milk and meat from livestock (e.g., dairy and beef cattle) that drink well water 
- Ingestion of vegetables grown in garden soil irrigated with well water and containing drill cuttings

- Ingestion of milk and meat from livestock (e.g., dairy and beef cattle) that eat fodder from pasture irrigated with well water and containing drill cuttings

- Inhalation of well water used for irrigation

- Inhalation of dust from the soil that was irrigated with well water

- Ingestion of soil that was irrigated with well water

- Direct radiation exposure from radionuclides deposited on the soil that was irrigated with well water

\subsubsection{Air Pathway Modeling}

The air pathway analysis model, CAP88, is used to estimate dose to the MEI and therefore requires the use of MEI input parameters. Exposure parameters used in CAP88 V1.0 are described briefly in Lee (2001) and are taken primarily from Hamby (1991 and 1992). Bioaccumulation factors are listed in the model input documented at http://www.epa.gov/radiation/docs/cap88/cap88mf_guide.htm.

Members of the public and intruders may be exposed to releases of radionuclides into the air from groundwater wells and surface water (i.e., volatile radionuclides such as $\mathrm{H}-3, \mathrm{C}-14, \mathrm{I}-129)$ are exposed through:

- Direct plume shine

- Inhalation

- Ingestion of milk and meat from livestock (e.g., dairy and beef cattle) that were exposed to airborne radioactivity

- Ingestion of vegetables grown in garden soil exposed to airborne radioactivity

- Ingestion of milk and meat from livestock (e.g., dairy and beef cattle) that eat fodder from pastures that were exposed to airborne radioactivity

\subsection{Literature Review}

Numerous studies have been reviewed to update and baseline human health exposure parameters and quantify transfer factors for specific chemical elements as a function of food type. These studies have been compiled in several publications. Most computer codes reference one or more of these compilations as the source of their transfer factors.

\subsubsection{Human Health Exposure Parameter}

Site-specific information is available for most of the human health exposure parameters required to estimate doses. Hamby (1991) surveyed county agents in South Carolina and Georgia and compiled county-specific statistics on land and water use within a 50-mile radius of SRS. These data were peer reviewed and published in Hamby (1992). Recent efforts are ongoing to update these data including a recent update to the survey to reflect comments received by county agents.

Where Hamby and other site- or regional- specific studies (i.e. CDC Dose Reconstruction Study) do not provide site-specific information for physical parameters and consumption rates, global data are used. Yu et al. (1993 and 2001) provided data for use in RESRAD, a NRC and DOE supported dose model, based on literature review of standard values and publications. The EPA Exposure Factors Handbook (EPA 1997) summarizes and recommends human health exposure parameter data for human exposure to environmental contaminants based on studies published 
through August 30, 1997. (Kennedy and Strenge 1992) provides generic and site-specific human health data for estimating dose from exposure to residual radioactive contamination. The general hierarchy of the global data use is listed below:

\#1. Hamby (1991and 1992) - site-specific

\#2. Other site- or regional- specific publications

\#3. EPA Exposure Factors Handbook (EPA 1997)

\#4. RESRAD Version 6 (Yu et al. 2001)

\#5. NUREG/CR-5512 (Kennedy and Strenge 1992)

Isolated situations where other sources of data are used that do not follow the hierarchy listed above are identified in the text.

\subsubsection{Bioaccumulation Data}

Several frequently referenced compilations of element-specific transfer factors include the International Atomic Energy Agency's Technical Report Series \#364, Handbook of Parameter Values for the Prediction of Radionuclide Transfer in Temperate Environments (IAEA 1994). This document encompasses a wide variety of plant types and is the result of extensive background investigations. It is based on data compiled by the International Union of Radioecologists. A second frequently cited reference is the NUREG/CR-5512, Residual Radioactive Contamination from Decommissioning: Technical Basis for Translating Contamination Levels to Annual Total Effective Dose Equivalent (Kennedy and Strenge 1992) because of its large set of data and traceable references. Other references include the National Council on Radiation Protection and Measurements (NCRP) Report \#123 (1996), Screening Models for Releases of Radionuclides to Atmosphere, Surface Water, and Ground, and the series of documents by Coughtrey and Thorne (1983), Radionuclide Distribution and Transport in Terrestrial and Aquatic Ecosystems, Vols. 1-6.

A recent compilation of reviews was determined to contain a hierarchy utilizing the more recent and relevant literature references and the document was reviewed and determined adequate to document a baseline for transfer factors. After extensive review of the above references, SRS has decided to incorporate PNNL-13421 (Staven et al. 2003) into the site hierarchy of transfer value tables for input parameters to SRS performance assessments. PNNL 13421, A Compendium of Transfer Factors for Agricultural and Animal Products, was issued June 2003. This document was developed in conjunction with the upgrade to the GENII system of computer codes. The GENII computer code was developed to incorporate the internal dosimetry models recommended by the International Commission on Radiological Protection (ICRP) and the radiological risk estimating procedures of Federal Guidance Report 13 into updated versions of existing environmental pathway analysis models. GENII and the Windows compatible GENII-Version 2 provide state-of-the art, technically peer-reviewed, and documented set of programs for calculating radiation dose and risk from radionuclides released to the environment. Upgrading the codes to GENII-Version 2 provided the opportunity to update and further document the library of transfer factors that support the environmental pathway analyses. Table 2-1 lists the hierarchy of sources of bioaccumulation data used for this report and its source as well as other DOE sites.

In general, site-specific values were used without modification where appropriate. When recent generic compilations were used and the differences were larger than two orders of magnitude, a geometric mean of the generic updated value and the currently used value was selected as a method for averaging the ratios (Wilkipedia 2006). 
Table 2-1. Hierarchy of Reference Used for Bioaccumulation Sources

\begin{tabular}{|c|c|c|c|c|c|c|c|c|c|c|}
\hline & \multicolumn{5}{|c|}{ Literature } & \multicolumn{3}{|c|}{ SRS } & \multicolumn{2}{|c|}{ Other DOE Sites PA } \\
\hline & $\begin{array}{c}\text { Staven et al. } \\
2003^{*}\end{array}$ & $\begin{array}{c}\text { Baes and } \\
\text { Sharp 1984 }\end{array}$ & $\begin{array}{l}\text { Kennedy and } \\
\text { Strenge } 1992^{\ddagger}\end{array}$ & NRC $1977^{\S}$ & CDC 2006 & $\begin{array}{l}\text { Koffman } \\
\text { 2006; } \\
\text { Lee } 2004^{* *}\end{array}$ & $\begin{array}{c}\text { Jannik and } \\
\text { Dixon } 2006^{\dagger+}\end{array}$ & This Document & Hanford $2004^{\S \S}$ & Idaho $2003^{* * *}$ \\
\hline & $\begin{array}{c}\text { PNNL- } \\
134219 / 03\end{array}$ & $\begin{array}{c}\text { ORNL - } \\
57869 / 04\end{array}$ & $\begin{array}{l}\text { NUREG/CR- } \\
\text { 5512, Vol. } 1\end{array}$ & $\begin{array}{c}\text { Reg Guide } \\
1.109 \\
\end{array}$ & $\begin{array}{c}\text { SRS Dose } \\
\text { Reconstruction } \\
9 / 06 \\
\end{array}$ & $\begin{array}{c}\text { SRS Intruder } \\
\text { Application }\end{array}$ & $\begin{array}{c}\text { SRS LADTAP } \\
\text { Application }\end{array}$ & $\begin{array}{l}\text { SRS Future } \\
\text { Baseline }\end{array}$ & $\begin{array}{c}\text { Hanford Tank Waste PA } \\
\text { June }\end{array}$ & Idaho 4/03 \\
\hline$\# 1$ & $\begin{array}{c}\text { IAEA-364 } \\
1994\end{array}$ & RG 1.109 & \begin{tabular}{|c} 
IUR sixth \\
working group \\
1989 \\
\end{tabular} & $\begin{array}{c}\text { Site } \\
\text { Specific }\end{array}$ & $\begin{array}{c}\text { Site Specific } \\
\text { Hamby/ } \\
\text { Friday }\end{array}$ & $\begin{array}{l}\text { Hamby } 1992 \\
\text { Site specific }\end{array}$ & RG 1.1091977 & $\begin{array}{l}\text { Site Specific } \\
\text { Hamby/Friday }\end{array}$ & $\begin{array}{c}\text { PNWD-2023 (1994) } \\
\text { Hanford Environmental } \\
\text { Dose Reconstruction } \\
\text { Project }\end{array}$ & $\begin{array}{l}\text { Site Specific Yucca } \\
\text { Mtn Maheras } 1997\end{array}$ \\
\hline \#2 & \begin{tabular}{|c|} 
NUREG/CR- \\
55121992
\end{tabular} & $\begin{array}{l}\text { TERRA } \\
\text { Code }\end{array}$ & IAEA 364 & $\begin{array}{l}\text { UCRL- } \\
\text { 50163 Prt } \\
\text { IV } 1968\end{array}$ & IAEA-364 & \begin{tabular}{|c|} 
ORNL-5786 \\
Baes and \\
Sharp 1984
\end{tabular} & $\begin{array}{c}\text { RESRAD } \\
\text { Yu et al. } 2001\end{array}$ & PNNL-13421 2003 & IAEA-364 & Baes/Ortin 1979 \\
\hline \#3 & \begin{tabular}{|c|} 
NRCP \#123 \\
1996
\end{tabular} & & $\begin{array}{c}\text { Cf- Strenge } \\
1987\end{array}$ & & GenII Default & $\begin{array}{c}\text { RG } 1.109 \\
1977\end{array}$ & \begin{tabular}{|c|} 
ORNL-5786 \\
Baes and Sharp \\
1984 \\
\end{tabular} & $\begin{array}{c}\text { ORNL-5786 Baes } \\
\text { and Sharp } 1984\end{array}$ & $\begin{array}{c}\text { ORNL-5786 Baes and } \\
\text { Sharp } 1984\end{array}$ & ORNL-5786 1984 \\
\hline$\# 4$ & \begin{tabular}{|l|} 
GENII Code \\
Napier 1988
\end{tabular} & & & & & & & NCRP \#123 & NUREG/CR-5512 & \\
\hline$\# 5$ & \begin{tabular}{|c|} 
Coughtrey/ \\
Thorne \\
Vol 1-6 1983 \\
\end{tabular} & & & & & & & & NCRP \#123 & \\
\hline
\end{tabular}

\footnotetext{
* Prepared as part of GENII-Version2 Upgrading

${ }^{\dagger}$ Review / Analysis Parameters for Transport of Released Radionuclides Through Agriculture

${ }^{\ddagger}$ Residual Radioactive Contamination from Decommissioning

$\S$ Regulatory Guidance Calculation of Annual Doses from Routine Reactor Releases

** Automated Application Excel Calculation Intruder Dose

${ }^{\dagger \dagger}$ Excel Application Environmental Dose Assessment Maximum Exposed Individual

㧊 PA Input for SRS facilities

$\S \S$ Hanford PA for tanks

${ }^{* * *}$ Idaho PA Tank Farm
} 


\subsection{PHYSICAL HUMAN HEALTH EXPOSURE PARAMETERS}

Physical parameters required for evaluating pathway-specific dose for performance assessments are areal and physical density of soil; atmospheric mass loading of soil particulates while working in garden and residing in home; depth of garden, rate of irrigation for garden; fraction of the year that crops are irrigated; weathering removal rate constant for crops, time periods that soil (buildup time), crops and pasture are exposed to irrigation; pasture grass, agricultural and vegetable crop yields; area of garden; fractional retention of deposition on leaves; and erosion rate. Many of these parameters are generic in nature and are based on industry recommendations.

This report provides updates for continued use of some parameters listed and provides some background for site-specific parameters and those where updates are provided. A summary of current and updated productivity and physical parameters are listed in Table 3-1 and Table 3-2 and, respectively. These factors for all references considered are listed in APPENDIX A.

\subsection{Crop Yields}

Hamby (1991) surveyed 21 county extension agents in Georgia and South Carolina to estimate the average mass, in kilograms, of vegetation harvested in a typical square meter of garden or farmland within a 50-mile radius of SRS. Crop yields in $\mathrm{kg} / \mathrm{m}^{2}$ were estimated for leafy vegetation (cabbage, lettuce and spinach) and other aboveground vegetables (broccoli, cauliflower, green peas, lima beans, and sweet corn). Average agricultural, garden, and pasture grass productivity for farms in the 50-mile region is estimated to be $0.7 \mathrm{~kg} / \mathrm{m}^{2}, 0.2 \mathrm{~kg} / \mathrm{m}^{2}$ and 1.8 $\mathrm{kg} / \mathrm{m}^{2}$, respectively. Because the garden productivity was estimated to be an order of magnitude lower than the NRC default (NRC 1977), Hamby (1991) assumed the garden productivity is to be equal to agricultural productivity. This report recommends use of the site-specific value of 0.7 $\mathrm{kg} / \mathrm{m}^{2}$ as the expected value for garden productivity, and the $0.2 \mathrm{~kg} / \mathrm{m}^{2}$ should be considered in the uncertainty range.

\subsection{Fraction of Foodstuff Intake from Garden}

The current assumption of the fractions of vegetables, milk, and meat intake that is from a local garden were based on NRC (1977), professional judgment, and Yu et al. (2001) which considers the 0.5 fraction of vegetable intake to be a maximum value. Table 13-71 of the EPA EFH (EPA 1997) provides regional values for vegetables, milk, and meat intake fractions and scenariospecific values. This report recommends use of the values provided in EPA (1997) for households with gardens who raise animals for an all pathways analysis and those for households who farm for an intruder analysis.

\subsection{Area of Garden}

The garden size of $100 \mathrm{~m}^{2}$ for a family of four is assumed in SRS PAs and is based on a sitespecific evaluation of consumption needs and annual productivity. It is assumed that a well would not be drilled for a single individual but rather for a household that includes at least two adults. As will be discussed in Section 4.4, Hamby (1991) estimated that a person within a 50 mile radius of SRS consumes $184 \mathrm{~kg}$ of vegetables annually. Section 3.1 discusses the average garden vegetable yield of $0.2 \mathrm{~kg} / \mathrm{m}^{2}$ but recommends the use of the agricultural $0.7 \mathrm{~kg} / \mathrm{m}^{2}$ as in Hamby (1991). A garden size of $260 \mathrm{~m}^{2}$ would be required to support the annual consumption of $184 \mathrm{~kg}$ of vegetables for a household with two adults assuming all vegetables consumed by the adults are from their garden. Assuming that only $17 \%$ of a person's vegetables are from their home garden (EPA 1997), roughly $100 \mathrm{~m}^{2}$ would be required to feed a family of four. This report recommends 
use of the $100 \mathrm{~m}^{2}$ garden size for vegetables only. However, this area is not large enough to graze livestock. Yu et al. (2001) states that an area of 1 ha $\left(10,000 \mathrm{~m}^{2}\right)$ is required to graze a single milk cow.

\subsection{Soil Exposure Time Period}

Soil exposure time period to irrigation (buildup) Jannik and Dixon (2006) recommends $40 \mathrm{y}$ to indicate life time of facility releasing radionuclide and $1 / 2$ of a MEI lifetime assuming the MEI is exposed at that location for their lifetime. For the intruder and public scenario, it is assumed that the irrigation and harvesting of vegetables occur during the first year of residence, yielding the $183 \mathrm{~d}$ updated value. However, if the exposure continues throughout the period of residence, the lifetime of exposure could be 30 yrs, yielding the updated maximum range of 5458 days. 
Table 3-1. $\quad$ Updated Crop Exposure Times and Productivity

\begin{tabular}{|c|c|c|c|c|c|c|c|}
\hline Parameter & $\begin{array}{l}\text { SRS Current } \\
\text { Values }\end{array}$ & Reference & \multicolumn{2}{|c|}{ Update Value $^{*}$} & Reference & Min & Max \\
\hline Pasture exposure time to irrigation (d) & $30-60$ & NRC 1977 & \multicolumn{2}{|c|}{30} & Reg. Guide 1.109 & 30 & 365 \\
\hline $\begin{array}{l}\text { Vegetable crop exposure times to } \\
\text { irrigation }(\mathrm{d})^{\dagger}\end{array}$ & 70 & Hamby 1991 & \multicolumn{2}{|c|}{ N/A } & & 1.7 & 240 \\
\hline $\begin{array}{l}\text { Soil exposure time period to irrigation (d) } \\
\text { (Buildup time in soil) }\end{array}$ & $182-365$ & Scenario-specific $^{\ddagger}$ & \multicolumn{2}{|c|}{183} & Scenario-specific & 60 & 5458 \\
\hline \multicolumn{8}{|l|}{ Productivity } \\
\hline Pasture grass $\left(\mathrm{kg} / \mathrm{m}^{2}\right)$ & $1.8-2$ & Hamby 1991/NRC 1977 & \multicolumn{2}{|c|}{1.8} & Hamby 1991 & 0.7 & 2 \\
\hline Agricultural (veg/produce) $\left(\mathrm{kg} / \mathrm{m}^{2}\right)$ & $0.7-2$ & Hamby 1991/NRC 1977 & \multicolumn{2}{|c|}{0.7} & Hamby 1991 & 0.5 & 4 \\
\hline Vegetable crop yield $\left(\mathrm{kg} / \mathrm{m}^{2}\right)$ & $0.7-2$ & Hamby 1991/NRC 1977 & \multicolumn{2}{|c|}{0.7} & Hamby 1991 & 0.2 & 4 \\
\hline \multicolumn{3}{|l|}{ Fraction of Foodstuff Produced Locally } & $\begin{array}{c}\text { All } \\
\text { Pathway }\end{array}$ & Intruder & & & \\
\hline Vegetables & $0.5-1$ & Yu et al. 2001/NRC 1977 & 0.173 & 0.308 & EPA $1997^{\S}$ & 0 & 1 \\
\hline Meat & 1 & Yu et al. 2001/NRC 1977 & 0.306 & 0.319 & EPA $1997^{\S}$ & 0 & 1 \\
\hline Milk & 1 & Yu et al. 2001/NRC 1977 & 0.207 & 0.254 & EPA $1997^{\S}$ & 0 & 1 \\
\hline \multicolumn{8}{|c|}{ Dilution Factor for mixing of waste in vegetable garden } \\
\hline Agricultural scenario & 0.2 & Napier et al, 1984 & & N/A & & 0.2 & 0.2 \\
\hline Post-Drilling Scenario & 0.02 & McDowell-Boyer 2000 et al. & & N/A & & 0.002 & 0.02 \\
\hline
\end{tabular}

* N/A - no update recommended

${ }^{\dagger}$ average growing time for above ground vegetables

₹ Assumes intruder and public assumed to irrigate and grow vegetables during first yr of residence allowing a max buildup time of 1 yr. Updated value is $1 / 2$ that.

| § Table 13-71. Assumes member of the public (all pathway) has a garden ('households who garden') and the intruder has a farm ('households who farm').

** Based on professional judgment and conservative relative to value used at Oak Ridge. 
Table 3-2. Updated Physical Parameters

\begin{tabular}{|c|c|c|c|c|c|c|}
\hline \multirow[b]{2}{*}{ Parameter } & \multirow{2}{*}{$\begin{array}{c}\text { SRS Current } \\
\text { Values }\end{array}$} & \multirow[b]{2}{*}{ Reference } & \multicolumn{4}{|c|}{ Update Recommendation } \\
\hline & & & Value $^{*}$ & Reference & Min & Max \\
\hline Areal density of soil $\left(\mathrm{kg} / \mathrm{m}^{2}\right)$ & $240^{\dagger}$ & Hamby 1993b & $\mathrm{N} / \mathrm{A}$ & & 180 & 270 \\
\hline Soil Density $\left(\mathrm{kg} / \mathrm{m}^{3}\right)$ & $1,400^{\ddagger}$ & Baes and Sharp 1983 & 1,600 & Hamby 1993a & 1350 & 1600 \\
\hline \multicolumn{7}{|l|}{ Atmospheric mass loading of soil $\left(\mathrm{kg} / \mathrm{m}^{3}\right)$} \\
\hline while working in garden & $1.00 \mathrm{E}-07$ & McDowell-Boyer et al. $2000^{\S}$ & $\mathrm{N} / \mathrm{A}$ & & $9.00 \mathrm{E}-09$ & $1.30 \mathrm{E}-03$ \\
\hline while residing in home & $1.00 \mathrm{E}-08$ & McDowell-Boyer et al. $2000^{\S}$ & $\mathrm{N} / \mathrm{A}$ & & $6.80 \mathrm{E}-09$ & $2.54 \mathrm{E}-07$ \\
\hline Depth of garden (cm) & 15 & Hamby 1993a & N/A & & 15 & 61 \\
\hline Garden irrigation rate $\left(\mathrm{L} / \mathrm{d} / \mathrm{m}^{2}\right)$ & $3.4^{* *}$ & Hamby 1993b & $3.6^{* *}$ & Hamby 1993b & 2.08 & 8.47 \\
\hline Fraction of the yr that crops are irrigated & 0.2 & estimated (70/365) & N/A & & 0.2 & 1 \\
\hline Crop weathering constant (L/d) & $0.0495^{\dagger \dagger}$ & NRC 1977 & N/A & & 0.03 & 0.0495 \\
\hline Fractional retention of deposition on leaves & $0.25^{\ddagger \ddagger}$ & NRC 1977 & N/A & & 0.2 & 1 \\
\hline Area of garden for family of four $\left(\mathrm{m}^{2}\right)$ & 1,000 & Based on Section 3.3 estimate $^{\S \S}$ & 100 & Based on Section 3.3 estimate & 100 & 1000 \\
\hline
\end{tabular}

\footnotetext{
* N/A - no update recommended

${ }^{\dagger}$ Estimated based on $1600 \mathrm{~kg} / \mathrm{m}^{3}$ soil density* $0.15 \mathrm{~m}$ garden depth.

${ }^{\ddagger}$ Value in Baes and Sharp (1983) is 1350 and is assumed to be rounded up to 1400 .

$\S$ Based on professional judgment and consistent with literature which recommends a wide range of values

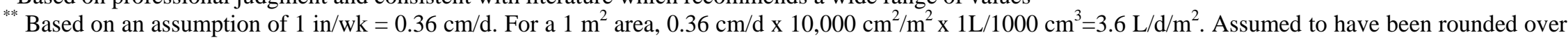
time. Updated value eliminates rounding errors.

${ }^{+\dagger}$ Based on 14 day half life for removal of activity from plants. $0.0021 \mathrm{hr}^{-1}$ reported in NRC (1977): 0.693/14 d = $0.495 \mathrm{~d}^{-1} * 1 \mathrm{~d} / 24 \mathrm{hr}=0.0021 \mathrm{hr}{ }^{-1}$

\# NRC (1977) recommends 1 for iodine’s and 0.2 for other particulates

$\S \S$ assumes $0.2 \mathrm{~kg} / \mathrm{m}^{2}$ productivity
} 


\subsection{CONSUMPTON RATES}

Consumption rates currently used at SRS and updated parameter values required for evaluating dose for the various exposure pathways are listed in Table 4-1. Parameters may vary with exposure scenario and are footnoted where different values are updated by a scenario.

Site-specific human health exposure parameters are available. In some cases, these values were being employed for the all pathways and inadvertent intruder analyses. However, in many cases the values employed are for the MEI. These recommendations are for the use of expected parameter values versus the conservative use of MEI parameters.

Usage parameters evaluated that are updated include water, vegetable, soil, and foodstuff consumption rates. These adjustments are based primarily on the availability of site-specific information and the use of conservative MEI parameters based on model defaults. Recommendations here attempt to advise the use of expected or average rates. These updated rates and suggested ranges for sensitivity and uncertain analyses are listed in Table 4-1. Values evaluated from other sources and used at other DOE facilities are listed in Table A- 3. Value ranges are based on those provided in the referenced literature from the hierarchy and the value ranges used at other DOE facilities..

\subsection{Water Ingestion}

Ingestion of water is a key usage factor for the all pathway and inadvertent intruder analyses. The rate of contaminated water consumption can vary by exposure scenario based on assumed access to the water supply. For the inadvertent intruder where the contaminated water is expected to come from a well an assumption can be made that water from the well is only used for cooking. Likewise, for the all pathway analyses the assumption could be made that total water intake comes from the contaminated community water supply. However, in the absence of site- and/or regional- specific surveys, global estimates are appropriate.

\subsubsection{SRS Water Ingestion}

The RESRAD (Yu et al. 2001) $511 \mathrm{~L} / \mathrm{yr}(1.4 \mathrm{~L} / \mathrm{d})$ average water ingestion rate updated for use in the all pathway analysis is based on EPA surveys published in the early 1990s. The $730 \mathrm{~L} / \mathrm{yr}$ (2 L/d) water ingestion rates for the inadvertent intruder are taken from Hamby (1992) and are based on NRC (1977) rates for the MEI. The average rate for ingestion of drinking water listed in those sources is $370 \mathrm{~L} / \mathrm{yr}(1 \mathrm{~L} / \mathrm{d})$. These publications consider indirect ingestion of water but do not consider whether or not the water is bottled or comes from a community or commercial source.

\subsubsection{Water Ingestion Update}

EPA (2004) estimates per capita ingestion of water using data from the combined 1994, 1995, 1996, and 1998 Continuing Survey of Food Intakes by Individuals (CSFII), conducted by the United States Department of Agriculture (USDA). This publication considers indirect ingestion of water from food with water added at the final phase of food preparation and reports water consumption from community water, bottled water, water from other sources, missing source, and total water. Summary data found in the Executive Summary (pages vii-viii) provide a $337 \mathrm{~L} / \mathrm{yr}$ water ingestion rate. 
Table 4-1. $\quad$ Updated Individual Exposure Times and Consumption Rates

\begin{tabular}{|c|c|c|c|c|c|}
\hline \multirow[b]{2}{*}{ Parameter } & \multirow{2}{*}{$\begin{array}{c}\text { SRS Current } \\
\text { Value }\end{array}$} & \multicolumn{4}{|c|}{ Update Recommendation } \\
\hline & & Value & Reference & Min & Max \\
\hline Breathing rate $\left(\mathrm{m}^{3} / \mathrm{yr}\right)$ & 8000 & 5,548 & EPA 1997 & 1,267 & 36,792 \\
\hline \multicolumn{6}{|l|}{ Consumption Rate } \\
\hline Soil (kg/yr) & 0.0365 & $0.0365^{*}$ & EPA 1997 & 0.0008 & 0.4 \\
\hline Leafy vegetable (kg/yr) & $14-21$ & $21^{\dagger}$ & Hamby 1992 & 4.3 & 64 \\
\hline Other vegetable (kg/yr) & $160-163$ & $163^{\dagger}$ & Hamby 1992 & 51 & 520 \\
\hline Meat (kg/yr) & 63 & 43 & Hamby 1992 & 26 & 110 \\
\hline Finfish (kg/yr) & 9 & $9^{\ddagger}$ & Hamby 1992 & 2.2 & 21 \\
\hline Seafood (kg/yr) & & $0^{\S}$ & Hamby 1992 & 0 & 5 \\
\hline Milk (L/yr) & 92 & 120 & Hamby 1992 & 20 & 310 \\
\hline Water (L/yr) & $511-730$ & 337 & EPA 2004 & 184 & 730 \\
\hline Fodder-Beef cattle (kg/d) & 50 & 36 & Hamby 1991 & 6 & 50 \\
\hline Fodder-Milk cattle (kg/d) & 50 & 52 & Hamby 1991 & 11 & 52 \\
\hline Fraction of milk-cow intake from pasture & 1 & 0.56 & Hamby 1992 & 0.0004 & 1 \\
\hline Fraction of beef-cow intake from pasture & 1 & 0.75 & Hamby 1992 & 0.0004 & 1 \\
\hline Water (beef cow) (L/d) & 50 & 28 & Hamby $1993 b$ & 28 & 50 \\
\hline Water (milk cow) (L/d) & 60 & 50 & Hamby $1993 b$ & 50 & 60 \\
\hline \multicolumn{6}{|l|}{ Exposure Time } \\
\hline Shoreline (hr/yr) & 23 & 23 & Hamby 1991 & 5 & 85 \\
\hline Swimming (hr/yr) & 8.9 & 8.9 & Hamby 1991 & 8.9 & 21 \\
\hline Boating ( hr/yr) & 21 & 21 & Hamby 1991 & 9.1 & 21 \\
\hline Showering (min/d) & & 10 & EPA 1977 & 10 & 30 \\
\hline Fraction of yr working in garden ( /yr) & 0.01 & 0.01 & Oztunali et al. 1981 & 0.01 & 0.08 \\
\hline Fraction of yr residing in home (/yr) & 0.5 & 0.7 & EPA 1997 & 0.1 & 0.7 \\
\hline Fraction of time cattle on pasture (/yr) & 1 & 1 & Hamby 1991 & 1 & 1 \\
\hline
\end{tabular}

${ }^{*}$ Converts to $100 \mathrm{mg} / \mathrm{d}$ child ingestion rate in EFH recommended for use for the agricultural scenario. Other scenarios should use the $0.019 \mathrm{~kg} / \mathrm{yr}$ EFH adult intake rate

$\mid{ }^{\dagger}$ Leafy and non-leafy vegetables are combined for the intruder (184 kg/yr total) and assume 31\% of a person’s vegetable intake is from their garden (Table 3-1) yielding a $57 \mathrm{~kg} / \mathrm{yr}$ input.

${ }^{\ddagger}$ Only valid if it is assumed that a pond is built at the location or and offsite assessment is done well beyond the 100-m.

$\S$ Value of 2 should be used if the dose to a person downriver (i.e. Savannah area). 
Table 4-1. $\quad$ Updated Individual Exposure Times and Consumption Rates (continued)

\begin{tabular}{|c|c|c|c|c|c|}
\hline \multirow[b]{2}{*}{ Parameter } & \multirow{2}{*}{$\begin{array}{c}\text { SRS Current } \\
\text { Value }\end{array}$} & \multicolumn{4}{|c|}{ Update Recommendation } \\
\hline & & Value & Reference & Min & Max \\
\hline \multicolumn{6}{|l|}{ Transport (d) } \\
\hline Vegetables & 14 & 6 & Yu et al. 2001 & 6 & 14 \\
\hline Feed-milk-man transport time & 3 & 3 & Hamby 1991 & 1 & 4 \\
\hline Time from slaughter to consumption & 6 & 6 & Hamby 1991 & 6 & 20 \\
\hline
\end{tabular}


According to EPA (2004), direct water is plain water ingested directly as a beverage and indirect water is water added to foods and beverages during final preparation at home, or by food service establishments such as school cafeterias and restaurants. An example of indirect water is water added to dry cake mix. Community water is tap water from the community water supply; bottled water is purchased plain water; other water is water obtained from a well or rain cistern (household's), spring (household's or public), or other source; and preparation water is water used to prepare foods and includes the water used to prepare foods at home and by local food service establishments (indirect water), as well as, water added by commercial food manufacturers. Missing water source indicates that a survey participant responded "don't know" or "not ascertained" to the survey question regarding the source of water and total water is the sum of direct and indirect water from all sources which includes community water, bottled water, other water and missing sources.

EPA (2004) reports the mean per capita total water ingestion is $1,233 \mathrm{~mL} / \mathrm{person} / \mathrm{d}$ ( $450 \mathrm{~L} / \mathrm{yr}$ ) when viewed across genders and all age categories with $75 \%$ from community water, $13 \%$ from bottled water, $10 \%$ from other sources (well, spring and cistern, etc.), and $2 \%$ from non identified sources. This yields a mean of $924 \mathrm{~mL} /$ person/d $(337 \mathrm{~L} / \mathrm{yr})$ from community water and 12.3 $\mathrm{mL} /$ person/d (4.5 L/yr) from other sources (well water).

This report recommends the use of $337 \mathrm{~L} / \mathrm{yr}$ for all pathway and inadvertent intruder analysis. The recommendation for the inadvertent intruder stems from the agricultural exposure scenario where it is assumed that all of the person's domestic water is from the well. Therefore, it is not reasonable to assume the $4.5 \mathrm{~L} / \mathrm{yr}$ EPA (2004) value stated above for other sources as it assumes this is only a portion of a person's water.

\subsection{Soil Ingestion}

Incidental ingestion of contaminated soil is a key usage parameter for the inadvertent intruder analyses. This parameter is expected to vary by exposure scenario based on the frequency of exposure to the contaminated soil.

\subsubsection{SRS Soil Ingestion}

The $0.037 \mathrm{~kg} / \mathrm{yr}(100 \mathrm{mg} / \mathrm{d})$ ingestion rate used in the inadvertent intruder analysis is the value recommended for a child in EPA (1997). This document recommends $50 \mathrm{mg} / \mathrm{d}$ (0.019 kg/yr) for an adult in industrial settings but $100 \mathrm{mg} / \mathrm{d}$ for agricultural scenarios. The current all pathways analysis does not consider ingestion of soil irrigated with contaminated water. Suggested values for that pathway if included can be found in Table 4-1.

\subsubsection{Soil Ingestion Update}

The $0.037 \mathrm{~kg} / \mathrm{yr}(100 \mathrm{mg} / \mathrm{d})$ soil ingestion rate used in the inadvertent intruder analysis is the value recommended for a child in EPA (1997). This document recommends $50 \mathrm{mg} / \mathrm{d}$ (0.019 $\mathrm{kg} / \mathrm{yr}$ ) for adults in an industrial setting. The $0.037 \mathrm{~kg} / \mathrm{yr}$ used for the agricultural scenario is reasonable since a permanent homestead is assumed with an extensive amount of time spent gardening.

Consideration of this pathway for a member of the public in future performance assessments would allow for a reduced soil ingestion rate based on the limited amount of time that the public would spend exposed to the contaminated soil. 


\subsection{Inhalation Rate}

Inhalation of air can vary by exposure scenario based on the expected level of activity. However, for the all pathways and inadvertent intruder analyses they are expected to be similar.

\subsubsection{SRS Inhalation Rate}

The current inhalation rate used is $8000 \mathrm{~m}^{3} / \mathrm{yr}$ which is the breathing rate recommended in NRC (1977) and is derived from data provided in ICRP-23 (ICRP 1974).

\subsubsection{Inhalation Rate Update}

The inadvertent intruder analysis uses the $8000 \mathrm{~m}^{3} / \mathrm{yr}$ breathing rate recommended in NRC (1977) and derived from ICRP (1974). According to EPA (1997), the mean adult female and male breathing rate for long-term exposures are $4113 \mathrm{~m}^{3} / \mathrm{yr}\left(11.3 \mathrm{~m}^{3} / \mathrm{d}\right)$ and $5548 \mathrm{~m}^{3} / \mathrm{yr}\left(15.2 \mathrm{~m}^{3} / \mathrm{d}\right)$, respectively. This report recommends the $5548 \mathrm{~m}^{3} / \mathrm{yr}$ inhalation rate for use in SRS performance assessments for long-term exposure scenarios.

If acute scenarios are addressed, short-term inhalation rates from EPA (1997) should be employed. According to EPA (1997) an adult performing light or moderate activities for a short period of time would breathe at a rate of $1 \mathrm{~m}^{3} / \mathrm{hr}\left(8760 \mathrm{~m}^{3} / \mathrm{yr}\right)$ and $1.6 \mathrm{~m}^{3} / \mathrm{hr}\left(14,016 \mathrm{~m}^{3} / \mathrm{yr}\right)$, respectively.

\subsection{Foodstuff Consumption}

For the inadvertent intruder, vegetable, milk and beef consumption rates are taken from Hamby (1992). These values are based on county specific statistics provided by the counties within the states of South Carolina and Georgia that fall within a 50-mile radius of SRS. This report recommends continued use of Hamby (1991 and 1992) as a reference for these values as they are based on a site-specific evaluation. However, this report recommends use of average values for performance assessment where the MEI values are currently used in some cases.

\subsection{Exposure Times}

Recreational usage exposure times are taken from Hamby (1991 and 1992). For the external and inhalation exposure pathways, Oztunali et al. (1981) determined that the inadvertent intruder person spends $1 \%$ of the year working in a garden $(\sim 100 \mathrm{~h} / \mathrm{yr})$ and $50 \%$ of the year in their ( $\sim 000 \mathrm{hr} / \mathrm{yr}$ ) residence. This report maintains the 0.01 time spent working in garden but adopts $16.4 \mathrm{hr} / \mathrm{d}$. (5,986 hr/yr) time spent inside provided by EPA (1997) that assumes a person spends $70 \%$ of the year in their home. A $10 \mathrm{~min} / \mathrm{d}$ showering exposure time was taken from EPA (1997). 
THIS PAGE INTENTIONALLY LEFT BLANK 


\subsection{BIOACCUMULATION FACTORS}

For performance assessments at SRS, soil-to-vegetable (also known as soil-to-plant ratios, plantto-soil ratios), feed-to-milk, feed-to-beef and water-to-fish transfer factors are the bioaccumulation factors considered. Soil-to-vegetable transfer factors determine the fraction of an element that is drawn from the soil into the edible plant. Feed-to-milk transfer factors represent the nuclide fraction transferred from fodder to milk. Feed-to-meat transfer factors represent the nuclide-specific fraction transferred from fodder to beef. Water-to-fish transfer factors are the equilibrium ratios between concentration in aquatic foods and concentration in water.

Current bioaccumulation factors used in SRS performance assessments and their sources are discussed in subsequent sections. This report recommends updating the factors using site-specific values when available but considers Staven et al. (2003) to be the most recent comprehensive evaluation of bioaccumulation factors and recommends this as the secondary source of values. Where bioaccumulation factors are not available in Staven et al. (2003), older sources are referenced in the following order: Kennedy and Strenge (1992), Baes et al. (1984), and NCRP (1996), currently used value (typically NRC [1977]).

Along with discussion on current factors used, updated element-specific bioaccumulation factors for select elements are listed in subsequent sections. For brevity, the text of this report focuses on a select list of radionuclides important to SRS performance assessments. A comprehensive list of recommended bioaccumulation factors are listed in APPENDIX B.

\subsection{Soil-to-Vegetable Transfer Factors}

Element-specific soil-to-vegetable transfer factors are ratios of the fraction of contaminant concentration in soil $(\mathrm{Bq} / \mathrm{kg}$ soil) that would be transferred into vegetable roots $(\mathrm{Bq} / \mathrm{kg}$ vegetable). Soil-to-vegetable transfer factors for the various elements are based primarily on published evaluations and compilations and model defaults which are generic in nature, with some elements based on site-specific information. The use of data from these sources was based on scientific judgment and ensures consistency among the adopted values. For the most part, it is assumed that vegetable consumption in the SRS area are root vegetables with a negligible intake of locally produced leafy vegetables and grains based on a site-specific land and water use evaluation (Hamby 1991 and 1992).

Observed values documented in reports vary widely, mainly the result of different soil and vegetation types and environmental conditions. In addition, management practices such as plowing, liming, fertilization and irrigation greatly affect uptake. Variability can also result if the whole plant is compared to uptake into parts of the plant, such as grain. The approach adopted by IAEA is that for plants consumed by humans, all transfer factors refer to the edible portions, e.g. grains or tubers. Data for animal foodstuffs generally refer to the whole plant.

\subsubsection{Summary of Current Value Estimation}

With the exception of hydrogen (NRC 1977) and carbon (Sheppard et al. 1991) isotopes, soil-toplant ratios for the inadvertent intruder analysis are taken from ORNL-5786 (Baes et al. 1984). ORNL-5786 gives concentration ratios for vegetative portions of food crops, which would apply to leafy vegetables, and for non-vegetative (reproductive) portions, which would apply to nonleafy vegetables. The values for non-vegetative portions of food crops were adopted for use because local productivity of non-leafy vegetables is expected to be considerably greater than that of leafy vegetables (Hamby 1991). Tables 5 and 6 in Hamby (1991) provide sector-specific root 
and leafy vegetable productivity for the sectors within a 50-mile radius of SRS. These data demonstrate that leafy vegetables are only $5 \%$ of the total vegetables produced around SRS. Therefore, the non-vegetative (non-leafy) soil-to-plant transfer factors are recommended for use as consistent with Baes et al. (1984).

The reported concentration ratios on a dry-weight basis for non-leafy vegetation were converted to a fresh-weight basis by multiplying by a factor of 0.43 , which represents an average conversion factor for all types of non-leafy vegetables. Baes et al. (1984) estimates the dry-to-wet conversion factor of 0.428 dry-to-wet conversion factor assuming 0.126, 0.222, and 0.888 (Baes et al. 1984, Table 2.3) dry-to-wet factors and 20\%, 42.2\%, and 32\% (Baes et al. 1984, Table 2.2) relative importance for exposed produce, protected produce and grains, respectively. Application of this factor to the dry soil-to-plant ratios in Figure 2.2 of Baes et al. (1984) yields the soil-tovegetable transfer factors in the "Intruder Analysis" column of Table 5-3.

For the all pathways analysis, LADTAP-PA (Jannik and Dixon 2006) employs soil-to-vegetable transfer factors in NRC (1977) where possible and for those not available in the regulatory guide Yu et al. (2001) and Baes et al. (1984) were used. These factors are listed in the "All Pathways" column of Table 5-3 for select radionuclides. For this analysis, hydrogen concentration in vegetables and foodstuff are assumed to equate to the concentration in the irrigation water.

The SRS adopted values of plant uptake factors used in the intruder and all pathway calculations and updated values based on discussions in subsequent sections are listed in Table 5-3 for select radionuclides. A comprehensive list of elements is in APPENDIX B.

\subsubsection{Site-specific Considerations}

For SRS this conversion factor should be adjusted since Hamby (1991) indicates that exposed and protected root vegetables are dominant for vegetable consumption in South Carolina. Eliminating the consideration for grains, a 0.191 conversion factor could be applied assuming a relative importance similar to the United States indicated in Baes et al. (1984). In addition, this estimate could be refined using a relative importance for South Carolina which was not provided in Baes et al. (1984). Information for Florida and Virginia provided in Table 2.2 of Baes et al. (1984) (see Table 5-1) are averaged since they are also southeastern states.

Table 5-1 Regional Relative Importance of Vegetables from ORNL-5786

\begin{tabular}{|l|c|c|c|c|}
\hline & \multirow{2}{*}{$\begin{array}{c}\text { Dry-to-wet weight } \\
\text { conversion factors }\end{array}$} & \multicolumn{3}{|c|}{ Relative Importance (\% Production) } \\
\cline { 3 - 5 } & & Florida & Virginia & Continental US \\
\hline Leafy vegetables & & 4.9 & 4.7 & 5.8 \\
\hline Exposed produces & 0.126 & 7.2 & 31.7 & 20 \\
\hline Protected produce & 0.222 & 87.4 & 34.9 & 42.2 \\
\hline Grains & 0.888 & 0.6 & 28.6 & 32 \\
\hline
\end{tabular}

Table 5-2 lists the regional and US conversion factors that are calculated with SRS site-specific consideration of exposed of primarily root vegetables. These values were estimated using the methodology in Baes et al. (1984) described in 5.1.1 where assuming 0.126 and 0.222 (Baes et al. 1984, Table 2.3) dry-to-wet factors and 20\% and 42.2\% (Baes et al. 1984, Table 2.2) relative importance for exposed produce and protected produce, respectively. 
Table 5-2. Site-specific Regional Conversion Factors for Soil-to-Vegetable Transfer Factors based on ORNL-5786

\begin{tabular}{|l|c|c|}
\hline \multirow{2}{*}{ Region } & \multicolumn{2}{c|}{ Conversion Factors } \\
\cline { 2 - 3 } & $\begin{array}{c}\text { Root Vegetable } \\
\text { Including Grains }\end{array}$ & $\begin{array}{c}\text { Root Vegetable } \\
\text { with No Grains }\end{array}$ \\
\hline Florida & 0.239 & 0.215 \\
\hline Area Harvested & 0.219 & 0.215 \\
\hline Production & 0.558 & 0.192 \\
\hline Virginia & 0.390 & 0.176 \\
\hline Area Harvested & 0.684 & 0.202 \\
\hline Production & 0.428 & 0.191 \\
\hline United States & 0.305 & $\mathbf{0 . 1 9 5}$ \\
\hline Area Harvested
\end{tabular}

\subsubsection{Updated Soil-to-Vegetable Transfer Factors}

Where site-specific soil-to-vegetable factors are not available in the most recent source, Staven et al. (2003), older sources are referenced for recommendation. The hierarchy of the references used beyond Staven et al. (2003) is as discussed in Section 5.0 and listed Table 2-1.

With the exception of NCRP (1996), soil-to-vegetable transfer factors are listed in the references based on dry weight. These factors are converted for fresh vegetable consumption as described in Section 5.1.1 using the site-specific regional conversion factor estimated in Table 5-2 which considers site-specific vegetable consumption (eliminating grains) and assumes southeast relative importance (dry weight factors provided in references are multiplied by 0.195). The resulting updated soil-to-vegetable transfer factors for select elements are listed in Table 5-3. Soil-tovegetable transfer factors for a comprehensive list of elements are in APPENDIX B, Table B-1. Updated values greater than two orders of magnitude from the currently used values are geometrically averaged to estimate the final updated value. The range of values listed in these tables include those evaluated in the hierarchy, values listed from other DOE sites and sources along with their ranges, and values estimated using non-regional and site-specific dry-to-wet ratios which are not listed in APPENDIX B. 
Table 5-3. Updated Soil-to-Vegetable Transfer Factors for Select Elements

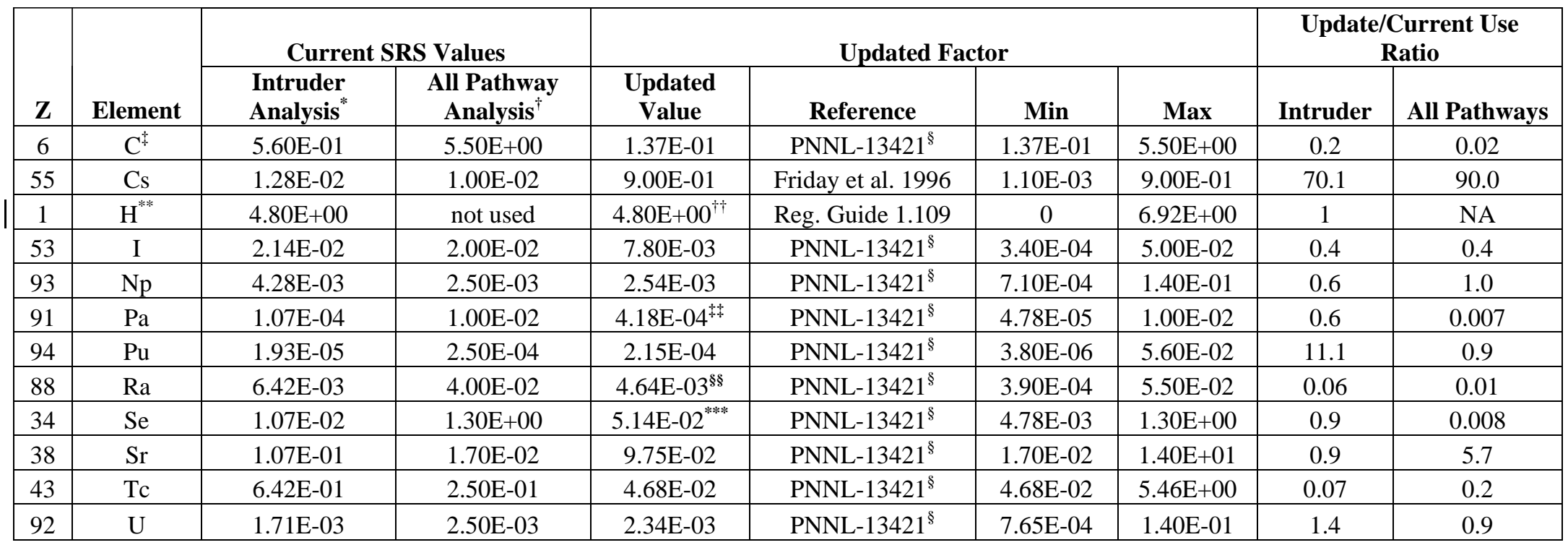

\footnotetext{
*Taken from Fig 2.2 in ORNL-5786 (Baes et al. 1984) with the 0.428 exposed, protected, and grains dry-to-wet conversion factor applied

${ }^{\dagger}$ All pathway values taken from NRC (1977), Yu et. al. (2001), Baes et al. (1984)

Intruder value for $\mathrm{C}$ is based on Sheppard et al. (1991) x 0.43

${ }^{\S}$ Dry weight values from reference are multiplied by 0.195 based on Section 5.1.2.

** Intruder H transfer factor is taken directly from Reg. Guide 1.109 (NRC 1977), Table E-1. All Pathways assumes H-3 concentration in water equates to the plant concentration.

${ }^{+\dagger} 1.0 \mathrm{E}+01$ for all pathways analysis (water pathways)

${ }^{\sharp}$ Geometric mean of PNNL-13421 site-specific value (6.83E-05) and currently used intruder and all pathways values.

${ }^{\S \S}$ Geometric mean of PNNL-13421 site-specific value (3.90E-04) and currently used intruder and all pathways values.

${ }^{* * *}$ Geometric mean of PNNL-13421 site-specific value (9.75E-03) and currently used intruder and all pathways values.
} 


\subsection{Feed-to-Milk Transfer Factors}

Feed-to-milk transfer factors represent the nuclide fraction transferred from fodder to milk. They represent the fraction of daily elemental intake in feed $(\mathrm{Bq} / \mathrm{d})$ with is transferred to a liter of milk (Bq/L milk per Bq/d intake). Current values are taken from NRC (1977). Updated values are based on the hierarchy discussed in Section 5.0. Existing and updated feed-to-milk transfer factors are listed in Table 5-4. Feed-to-milk transfer factors for a comprehensive list of elements are in APPENDIX B, Table B- 2. Updated values greater than two orders of magnitude from the currently used values are geometrically averaged to estimate the final updated value. Baes et al. (1984) reports feed-to-milk transfer factors in $\mathrm{d} / \mathrm{kg}$ and states a 1.028 to $1.035 \mathrm{~kg} / \mathrm{L}$ range for the density of milk. Feed-to-milk values in APPENDIX B are those reported by Baes et al. (1984) multiplied by $1.03 \mathrm{~kg} / \mathrm{L}$. The range of values listed in these tables includes those evaluated in the hierarchy and values listed from other DOE sites and sources along with their ranges.

Table 5-4. $\quad$ Updated Feed-to-Milk Transfer Factors (d/L) for Select Elements

\begin{tabular}{|c|c|c|c|c|c|c|c|}
\hline & & & & \multicolumn{3}{c|}{ Updated Factors } & \multirow{2}{*}{$\begin{array}{c}\text { Update/Current } \\
\text { Use Ratio }\end{array}$} \\
\cline { 5 - 8 } Z & & $\begin{array}{c}\text { Current } \\
\text { ERS } \\
\text { Ealues }\end{array}$ & $\begin{array}{c}\text { Hierarchy } \\
\text { Transfer } \\
\text { Factor }\end{array}$ & Reference & Min & Max & 1 \\
\hline 6 & $\mathrm{C}$ & $1.2 \mathrm{E}-02$ & $1.20 \mathrm{E}-02$ & Reg. Guide 1.109 & $1.05 \mathrm{E}-02$ & $1.20 \mathrm{E}-02$ & 0.7 \\
\hline 55 & $\mathrm{Cs}$ & $1.2 \mathrm{E}-02$ & $7.90 \mathrm{E}-03$ & PNNL-13421 & $7.00 \mathrm{E}-03$ & $1.20 \mathrm{E}-02$ & NA \\
\hline 1 & $\mathrm{H}$ & Not used & $1.50 \mathrm{E}-02$ & PNNL-13421 & 0 & $1.50 \mathrm{E}-02$ & 1.5 \\
\hline 53 & $\mathrm{I}$ & $6.0 \mathrm{E}-03$ & $9.00 \mathrm{E}-03$ & PNNL-13421 & $6.00 \mathrm{E}-03$ & $1.20 \mathrm{E}-02$ & 1 \\
\hline 93 & $\mathrm{~Np}$ & $5.0 \mathrm{E}-06$ & $5.00 \mathrm{E}-06$ & PNNL-13421 & $5.00 \mathrm{E}-06$ & $1.00 \mathrm{E}-05$ & 1 \\
\hline 91 & $\mathrm{~Pa}$ & $5.0 \mathrm{E}-06$ & $5.00 \mathrm{E}-06$ & PNNL-13421 & $5.00 \mathrm{E}-06$ & $5.15 \mathrm{E}-06$ & 0.6 \\
\hline 94 & $\mathrm{Pu}$ & $2.0 \mathrm{E}-06$ & $1.10 \mathrm{E}-06$ & PNNL-13421 & $1.00 \mathrm{E}-07$ & $2.00 \mathrm{E}-06$ & 1.3 \\
\hline 88 & $\mathrm{Ra}$ & $1.0 \mathrm{E}-03$ & $1.30 \mathrm{E}-03$ & PNNL-13421 & $4.50 \mathrm{E}-04$ & $1.30 \mathrm{E}-03$ & 0.09 \\
\hline 34 & $\mathrm{Se}$ & $4.5 \mathrm{E}-02$ & $4.00 \mathrm{E}-03$ & PNNL-13421 & $4.00 \mathrm{E}-03$ & $4.50 \mathrm{E}-02$ & 3.5 \\
\hline 38 & $\mathrm{Sr}$ & $8.0 \mathrm{E}-04$ & $2.80 \mathrm{E}-03$ & PNNL-13421 & $8.00 \mathrm{E}-04$ & $2.80 \mathrm{E}-03$ & $0.006^{\dagger}$ \\
\hline 43 & $\mathrm{Tc}$ & $2.5 \mathrm{E}-02$ & $1.87 \mathrm{E}-03^{*}$ & PNNL-13421 & $2.30 \mathrm{E}-05$ & $2.50 \mathrm{E}-02$ & 0.8 \\
\hline 92 & $\mathrm{U}$ & $5.0 \mathrm{E}-04$ & $4.00 \mathrm{E}-04$ & PNNL-13421 & $4.00 \mathrm{E}-04$ & $6.18 \mathrm{E}-04$ & \\
\hline
\end{tabular}

\subsection{Feed-to-Meat Transfer Factors}

Feed-to-meat transfer factors represent the nuclide-specific fraction transferred from fodder to beef. They represent the fraction of daily elemental intake in feed with is transferred to a $\mathrm{kg}$ of meat (Bq/kg meat per Bq/d intake). Currently values are taken from NRC (1977). Updated values are based on the hierarchy discussed in Section 5.0. Existing and updated feed-to-meat transfer factors are listed in Table 5-5. Feed-to-meat transfer factors for a comprehensive list of elements are in APPENDIX B, Table B- 3. Updated values greater than two orders of magnitude from the currently used values are geometrically averaged to estimate the final updated value. The range of values listed in these tables includes those evaluated in the hierarchy and values listed from other DOE sites and sources along with their ranges.

\footnotetext{
* Geometric mean of the PNNL-13241 value (1.4E-04) and currently used value.

${ }^{\dagger}$ Value greater than two orders of magnitude from the currently used values (update/current ratio $>100$ or $<0.01$ ) are geometrically averaged.
} 
Table 5-5. Updated Feed-to-Meat Transfer Factors (d/kg) for Select Elements

\begin{tabular}{|c|c|c|c|c|c|c|c|}
\hline \multirow[b]{2}{*}{$\mathbf{Z}$} & \multirow[b]{2}{*}{ Element } & \multirow[b]{2}{*}{$\begin{array}{c}\text { Current } \\
\text { SRS Value }\end{array}$} & \multicolumn{4}{|c|}{ Updated Factor } & \multirow[b]{2}{*}{$\begin{array}{c}\text { Update/Current Use } \\
\text { Ratio } \\
\end{array}$} \\
\hline & & & $\begin{array}{c}\text { Updated } \\
\text { Value } \\
\end{array}$ & Reference & Min & Max & \\
\hline 6 & $\mathrm{C}$ & $3.1 \mathrm{E}-02$ & $3.10 \mathrm{E}-02$ & Reg. Guide 1.109 & $3.10 \mathrm{E}-02$ & 4.89E-02 & 1.0 \\
\hline 55 & Cs & 4.0E-03 & $5.00 \mathrm{E}-02$ & PNNL-13421 & $4.00 \mathrm{E}-03$ & $5.00 \mathrm{E}-02$ & 12.5 \\
\hline 1 & $\mathrm{H}$ & Not Used & $1.2 \mathrm{E}-02$ & Reg. Guide 1.109 & 0 & $1.20 \mathrm{E}-02$ & NA \\
\hline 53 & $\mathrm{I}$ & 2.9E-03 & $4.00 \mathrm{E}-02$ & PNNL-13421 & $2.90 \mathrm{E}-03$ & 4.00E-02 & 13.8 \\
\hline 93 & $\mathrm{~Np}$ & $2.0 \mathrm{E}-04$ & $1.00 \mathrm{E}-03$ & PNNL-13421 & $5.50 \mathrm{E}-05$ & $1.00 \mathrm{E}-03$ & 5.0 \\
\hline 91 & $\mathrm{~Pa}$ & $5.0 \mathrm{E}-03$ & 4.47E-04* & PNNL-13421 & $5.00 \mathrm{E}-06$ & $5.00 \mathrm{E}-03$ & 0.008 \\
\hline 94 & $\mathrm{Pu}$ & $1.4 \mathrm{E}-05$ & $1.00 \mathrm{E}-05$ & PNNL-13421 & $5.00 \mathrm{E}-07$ & $1.00 \mathrm{E}-04$ & 0.7 \\
\hline 88 & $\mathrm{Ra}$ & $1.0 \mathrm{E}-03$ & $9.00 \mathrm{E}-04$ & PNNL-13421 & $2.50 \mathrm{E}-04$ & $1.00 \mathrm{E}-03$ & 0.9 \\
\hline 34 & Se & $1.5 \mathrm{E}-02$ & $1.50 \mathrm{E}-02$ & PNNL-13421 & $1.50 \mathrm{E}-02$ & $1.00 \mathrm{E}-01$ & 1.0 \\
\hline 38 & $\mathrm{Sr}$ & $6.0 \mathrm{E}-04$ & 8.00E-03 & PNNL-13421 & $3.00 \mathrm{E}-04$ & $1.00 \mathrm{E}-02$ & 13.3 \\
\hline 43 & $\mathrm{Tc}$ & 4.0E-01 & $6.32 \mathrm{E}-03^{\dagger}$ & PNNL-13421 & $1.00 \mathrm{E}-04$ & 4.00E-01 & 0.0003 \\
\hline 92 & $\mathrm{U}$ & $3.4 \mathrm{E}-04$ & $3.00 \mathrm{E}-04$ & PNNL-13421 & $2.00 \mathrm{E}-04$ & 8.00E-04 & 0.9 \\
\hline
\end{tabular}

\subsection{Water-to-Fish Accumulation}

Element-specific water-to-fish bioaccumulation factors are ratios of the fraction of contaminant concentration in water $(\mathrm{Bq} / \mathrm{L})$ that would be transferred into fish muscle $(\mathrm{Bq} / \mathrm{kg})$. SRS values assume freshwater fish.

With the exception of a site-specific factor of 3,000 L/kg for cesium accumulation in freshwater fish (Jannik 2003), existing aquatic animal bioaccumulation factors, which are the equilibrium ratios between concentration in aquatic foods and concentration in water, can be found in (Jannik and Dixon 2006).

Updated values are based on the hierarchy discussed in Section 5.0. Fish data from Friday (2006) were collected at SRS in ponds having extremely contaminated sediments and employing sampling methods (filtering water before measurement) that would result in very high factors. These values are not recommended for use in this update because of the limitations. However, the data are included in the uncertainty range. Existing and updated water-to-fish transfer factors are listed in Table 5-6. Water-to-fish transfer factors for a comprehensive list of elements are in APPENDIX B, Table B- 4. Updated values greater than two orders of magnitude from the currently used values are geometrically averaged to estimate the final updated value. The range of

\footnotetext{
*Geometric mean of PNNL-13421 site-specific value (4.00E-05) and currently used value.

†Geometric mean of PNNL-13421 site-specific value (1.00E-04) and currently used value.
} 
values listed in these tables includes those evaluated in the hierarchy and values listed from other DOE sites and sources along with their ranges which may not be listed in the appendices.

Table 5-6. Updated Water-to-Fish Accumulation Factors $(\mathrm{L} / \mathrm{kg})$ for Select Elements

\begin{tabular}{|c|c|c|c|c|c|c|c|}
\hline \multirow[b]{2}{*}{$\mathbf{Z}$} & \multirow[b]{2}{*}{ Element } & \multirow{2}{*}{$\begin{array}{c}\text { Current } \\
\text { SRS } \\
\text { Value }\end{array}$} & \multicolumn{4}{|c|}{ Updated Factor } & \multirow[b]{2}{*}{$\begin{array}{c}\text { Update/Current } \\
\text { Use Ratio }\end{array}$} \\
\hline & & & $\begin{array}{c}\text { Updated } \\
\text { Value }\end{array}$ & Reference & Min & Max & \\
\hline 6 & $\mathrm{C}$ & $4.6 \mathrm{E}+03$ & $5.00 \mathrm{E}+04$ & PNNL-13421 & $4.60 \mathrm{E}+03$ & $5.00 \mathrm{E}+04$ & 10.9 \\
\hline 55 & $\mathrm{Cs}$ & $3.0 \mathrm{E}+03$ & $3.00 \mathrm{E}+03$ & Jannik 2003 & $2.00 \mathrm{E}+03$ & $4.70 \mathrm{E}+03$ & 1.0 \\
\hline 1 & $\mathrm{H}$ & $9.0 \mathrm{E}-01$ & $1.00 \mathrm{E}+00$ & NCRP 123 & $9.00 \mathrm{E}-01$ & $1.00 \mathrm{E}+00$ & 1.1 \\
\hline 53 & $\mathrm{I}$ & $1.5 \mathrm{E}+01$ & $4.00 \mathrm{E}+01$ & PNNL-13421 & $1.50 \mathrm{E}+01$ & $5.00 \mathrm{E}+02$ & 2.7 \\
\hline 93 & $\mathrm{~Np}$ & $1.0 \mathrm{E}+02$ & $2.10 \mathrm{E}+01$ & PNNL-13421 & $2.10 \mathrm{E}+01$ & $2.50 \mathrm{E}+02$ & 0.2 \\
\hline 91 & $\mathrm{~Pa}$ & $1.1 \mathrm{E}+01$ & $1.00 \mathrm{E}+01$ & PNNL-13421 & $1.00 \mathrm{E}+01$ & $1.13 \mathrm{E}+01$ & 0.9 \\
\hline 94 & $\mathrm{Pu}$ & $3.5 \mathrm{E}+00$ & $3.00 \mathrm{E}+01$ & PNNL-13421 & $3.50 \mathrm{E}+00$ & $4.70 \mathrm{E}+03$ & 8.6 \\
\hline 88 & $\mathrm{Ra}$ & $5.0 \mathrm{E}+01$ & $5.00 \mathrm{E}+01$ & PNNL-13421 & $5.00 \mathrm{E}+01$ & $7.00 \mathrm{E}+01$ & 1.0 \\
\hline 34 & Se & $1.7 \mathrm{E}+02$ & $1.70 \mathrm{E}+02$ & PNNL-13421 & $1.70 \mathrm{E}+02$ & $2.00 \mathrm{E}+02$ & 1.0 \\
\hline 38 & $\mathrm{Sr}$ & $3.0 \mathrm{E}+01$ & $6.00 \mathrm{E}+01$ & PNNL-13421 & $3.00 \mathrm{E}+01$ & $4.05 E+02$ & 2.0 \\
\hline 43 & Tc & $1.5 \mathrm{E}+01$ & $2.00 \mathrm{E}+01$ & PNNL-13421 & $1.50 \mathrm{E}+01$ & $2.00 \mathrm{E}+01$ & 1.3 \\
\hline 92 & $\mathrm{U}$ & $2.0 \mathrm{E}+00$ & $1.00 \mathrm{E}+01$ & PNNL-13421 & $2.00 \mathrm{E}+00$ & $5.00 \mathrm{E}+01$ & 5.0 \\
\hline
\end{tabular}


THIS PAGE INTENTIONALLY LEFT BLANK 


\subsection{SUMMARY AND CONCLUSIONS}

\subsection{Summary of Updates}

Updated physical human health data (Table 3-1 and Table 3-2) include soil exposure time period to irrigation (buildup); pasture grass, agricultural (veg/produce), vegetable crop yield; fraction of vegetables produced locally; and fraction of leafy vegetables produced locally based on the recommended use of site-specific data primarily taken from Hamby (1991). Consumption rate updates (Table 4-1) are based on the availability of updated information and site-specific data. Element-specific bioaccumulation factor recommended updates (APPENDIX B) are based on availability of recent data based on the hierarchy discussed in Section 5.0 calling for the use of site-specific data when available and secondary sources, primarily Staven et al. (2003). Where large disparities occur ( $>2$ orders of magnitude), a geometric mean of the site specific and generic value was selected.

\subsection{Potential Impact on Performance Assessments}

The full potential impacts of the recommended updates can not be quantified until detailed sensitivity analyses are performed. Bioaccumulation factors are widely variable across the reviewed sources and are considered drastically different if beyond two orders of magnitude in the summary tables Table 5-3, Table 5-4, Table 5-5, and Table 5-6 and the comprehensive tables, Table B-1, Table B- 2, Table B- 3, and Table B- 4. The use of the geometric mean of the new and old factors reduced the variability leaving wide variability in some cases.

A preliminary sensitivity analysis was performed using the Automated Intruder Analysis Application Version 2 (Koffman 2006b) and LADTAP-PA (Jannik and Dixon 2006). A unit source term (i.e. $1 \mathrm{pCi} / \mathrm{g}$ ) for each of the listed isotopes was utilized for the analyses. These analyses indicate a decline in dose resulting from these updates (Table 6-1 and Table 6-2).

The intruder decrease in dose in Table 6-1 is due primarily to the fraction of homegrown vegetable consumed and inhalation rate listed in Table 3-1 and Table 4-1, respectively. The all pathway decline in dose using updated factors from this report in LADTAP-PA shown in Table 6-2 is primarily due to the fish bioaccumulation factors and fraction of homegrown foodstuff consumed updates listed in Table 5-6 and Table 3-1, respectively.

Because the air pathway analysis employs CAP88, the Environmental Protection Agency (EPA) model required for the compliance with 40 CFR 61, the National Emissions Standards for Hazardous Air Pollutants (NESHAPs), adapting this model for consistency with other exposure analyses may require agreement with the EPA. At SRS, efforts are ongoing to upgrade from the currently used version of CAP88 (V1.0) to the more recent EPA approved PC version (V3.0), which may employ some of the parameters and factors discussed in this report.

Preliminary estimates with GOLDSIM for a typical waste tank indicate that the use of the geometric mean averaging methodology would yield a difference of less than $1 \%$ for the total dose at the peak concentration time. Evaluations will be performed in the future to assess the need for further sensitivity analysis as modeling efforts are completed. 
Table 6-1. Intruder Preliminary Sensitivity Analysis

\begin{tabular}{|l|c|c|c|c|c|}
\hline & \multicolumn{3}{|c|}{ Dose from 1 Ci Throughout Slit Trench (mrem/y) } & \multirow{2}{*}{ \% Change from } \\
\cline { 2 - 5 } Radionuclide & Baseline $^{*}$ & $\begin{array}{c}\text { Consumption Rate } \\
\text { and Physical }\end{array}$ & $\begin{array}{c}\text { Transfer } \\
\text { Factors }\end{array}$ & Combined & Baseline \\
\hline C-14 & $5.01 \mathrm{E}-02$ & $1.56 \mathrm{E}-02$ & $3.84 \mathrm{E}-03$ & $3.84 \mathrm{E}-03$ & $-92 \%$ \\
\hline Cs-137 & $4.14 \mathrm{E}-03$ & $2.21 \mathrm{E}-03$ & $4.62 \mathrm{E}-03$ & $4.62 \mathrm{E}-03$ & $11 \%$ \\
\hline H-3 & $4.81 \mathrm{E}-05$ & $1.50 \mathrm{E}-05$ & $1.50 \mathrm{E}-05$ & $1.50 \mathrm{E}-05$ & $-69 \%$ \\
\hline I-129 & $2.62 \mathrm{E}-01$ & $8.42 \mathrm{E}-02$ & $3.34 \mathrm{E}-02$ & $3.34 \mathrm{E}-02$ & $-87 \%$ \\
\hline Np-237 & $9.22 \mathrm{E}-01$ & $3.39 \mathrm{E}-01$ & $2.33 \mathrm{E}-01$ & $2.33 \mathrm{E}-01$ & $-75 \%$ \\
\hline Pa-231 & $8.12 \mathrm{E}-01$ & $5.21 \mathrm{E}-01$ & $5.16 \mathrm{E}-01$ & $5.16 \mathrm{E}-01$ & $-37 \%$ \\
\hline Pu-238 & $2.77 \mathrm{E}-02$ & $2.34 \mathrm{E}-02$ & $2.34 \mathrm{E}-02$ & $2.34 \mathrm{E}-02$ & $-16 \%$ \\
\hline Pu-239 & $6.74 \mathrm{E}-02$ & $5.68 \mathrm{E}-02$ & $5.68 \mathrm{E}-02$ & $5.68 \mathrm{E}-02$ & $-16 \%$ \\
\hline Ra-226 & $1.38 \mathrm{E}+00$ & $5.35 \mathrm{E}-01$ & $4.32 \mathrm{E}-01$ & $4.32 \mathrm{E}-01$ & $-69 \%$ \\
\hline Se-79 & $4.20 \mathrm{E}-03$ & $1.39 \mathrm{E}-03$ & $1.28 \mathrm{E}-03$ & $1.28 \mathrm{E}-03$ & $-70 \%$ \\
\hline Sr-90 & $5.98 \mathrm{E}-02$ & $1.88 \mathrm{E}-02$ & $9.93 \mathrm{E}-03$ & $9.93 \mathrm{E}-03$ & $-83 \%$ \\
\hline Tc-99 & $4.08 \mathrm{E}-02$ & $1.27 \mathrm{E}-02$ & $9.45 \mathrm{E}-04$ & $9.45 \mathrm{E}-04$ & $-98 \%$ \\
\hline $\mathrm{U}-235$ & $4.11 \mathrm{E}-01$ & $2.60 \mathrm{E}-01$ & $2.59 \mathrm{E}-01$ & $2.59 \mathrm{E}-01$ & $-37 \%$ \\
\hline $\mathrm{U}-238$ & $4.02 \mathrm{E}-02$ & $1.70 \mathrm{E}-02$ & $1.84 \mathrm{E}-02$ & $1.84 \mathrm{E}-02$ & $-54 \%$ \\
\hline
\end{tabular}

Table 6-2. All Pathways Preliminary Sensitivity Analysis

\begin{tabular}{|l|c|c|c|c|c|}
\hline \multirow{2}{*}{ Radionuclide } & \multicolumn{3}{|c|}{ LADTAP-PA Dose (mrem/yr) } & \multirow{2}{*}{$\begin{array}{c}\text { \% Change } \\
\text { from Baseline }\end{array}$} \\
\cline { 2 - 5 } & Baseline $^{\dagger}$ & $\begin{array}{c}\text { Consumption Rate } \\
\text { and Physical }\end{array}$ & $\begin{array}{c}\text { Transfer } \\
\text { Factors }\end{array}$ & Combined & 位n \\
\hline C-14 & $1.57 \mathrm{E}+00$ & $2.18 \mathrm{E}-01$ & $3.30 \mathrm{E}-01$ & $2.91 \mathrm{E}-01$ & $-81 \%$ \\
\hline I-129 & $8.82 \mathrm{E}-05$ & $2.63 \mathrm{E}-05$ & $6.25 \mathrm{E}-05$ & $2.64 \mathrm{E}-05$ & $-70 \%$ \\
\hline Np-237 & $1.65 \mathrm{E}+00$ & $4.01 \mathrm{E}-01$ & $1.41 \mathrm{E}+00$ & $4.14 \mathrm{E}-01$ & $-75 \%$ \\
\hline Pa-231 & $1.66 \mathrm{E}+01$ & $5.33 \mathrm{E}+00$ & $1.55 \mathrm{E}+01$ & $5.83 \mathrm{E}+00$ & $-65 \%$ \\
\hline Pu-238 & $4.71 \mathrm{E}+01$ & $1.35 \mathrm{E}+01$ & $3.27 \mathrm{E}+01$ & $1.25 \mathrm{E}+01$ & $-73 \%$ \\
\hline Pu-239 & $1.11 \mathrm{E}+01$ & $3.60 \mathrm{E}+00$ & $1.16 \mathrm{E}+01$ & $5.52 \mathrm{E}+00$ & $-50 \%$ \\
\hline Ra-226 & $1.23 \mathrm{E}+01$ & $3.99 \mathrm{E}+00$ & $1.28 \mathrm{E}+01$ & $6.10 \mathrm{E}+00$ & $-50 \%$ \\
\hline Se-79 & $9.54 \mathrm{E}+00$ & $2.42 \mathrm{E}+00$ & $4.79 \mathrm{E}+00$ & $2.07 \mathrm{E}+00$ & $-78 \%$ \\
\hline Sr-90 & $2.19 \mathrm{E}+00$ & $2.15 \mathrm{E}-01$ & $5.40 \mathrm{E}-02$ & $2.42 \mathrm{E}-02$ & $-99 \%$ \\
\hline Tc-99 & $6.82 \mathrm{E}-01$ & $2.06 \mathrm{E}-01$ & $8.76 \mathrm{E}-01$ & $2.49 \mathrm{E}-01$ & $-64 \%$ \\
\hline U-235 & $1.95 \mathrm{E}-01$ & $1.89 \mathrm{E}-02$ & $9.21 \mathrm{E}-03$ & $2.32 \mathrm{E}-03$ & $-99 \%$ \\
\hline U-238 & $9.84 \mathrm{E}-01$ & $3.15 \mathrm{E}-01$ & $8.74 \mathrm{E}-01$ & $3.21 \mathrm{E}-01$ & $-67 \%$ \\
\hline
\end{tabular}

\footnotetext{
* Current values in intruder application version 2 (no waterborne pathways)

${ }^{\dagger}$ Current values in LADTAP-PA
} 


\subsection{REFERENCES}

Baes and Sharp 1983. Baes, C.F. III and Sharp, R.D. 1983. "A Proposal for Estimation of Soil Leaching Constants for Use in Assessment Models: J. Environ. Qual. 12, 17. 1983.

Baes et al. 1984. Baes, C.F. III, Sharp, R.D., Sjoreen, A.L., and Shor, R.W. A Review and Analysis of Parameters for Assessing Transport of Environmentally Released Radionuclides Through Agriculture, ORNL-5786, Oak Ridge National Laboratory, Oak Ridge, Tennessee. 1984.

Coughtrey and Thorne 1983. Coughtrey P. J. and Thorne M. C. Radionuclide Distribution and Transport in Terrestrial and Aquatic Ecosystems, Vols. 1-6. 1983.

CDC 2006. Risk-Based Screening of Radionuclide Releases from the Savannah River Site, Executive Summary, Sections 1-13, CDC, March 2005

DOE 1999. "Low-Level Waste Requirements," Chapter IV in Radioactive Waste Management Manual, USDOE M 435.1-1, U.S. Department of Energy, Washington, DC (July 9). 1999.

DOE 2006, Standard Review Plan for Activities Related to U.S. Department of Energy Waste Determination, Draft Report for Interim Use and Comment, NUREG-1854, May 2006

EPA 1989. Risk Assessment Guidance for Superfund. Volume I. Human Health Evaluation Manual (Part A), USEPA/540/1-89-002, Washington, DC.

EPA 1991. OSWER Directive 9285.6-03, Risk Assessment Guidance for Superfund, Volume I: Human Health Evaluation Manual, Supplemental Guidance, "Standard Default Exposure Factors”, EPA, March 1991.

EPA 1997. Exposure Factors Handbook Volume I-III, EPA/600/P-95/002Fa Environmental Protection Agency (EPA),Office of Research and Development, Washington, D.C., August 1997

EPA 2004. Drinking water survey Estimated Per Capita Water. Ingestion and Body Weight in the United States-An Update. Based on Data Collected by the United States Department of Agriculture's 1994-1996 and 1998 Continuing Survey of Food Intakes by Individuals.

Friday et al. 1996 et al. G.P. Friday, C.L. Cummins, and A.L. Schwartzman. Radiological Bioconcentration Factors for Aquatic, Terrestrial, and Wetland Ecosystems at the Savannah River Site”, WSRC-TR-96-0231. Westinghouse Savannah River Company Technical Report. 1996.

Hamby, 1991 Hamby, D.M. Land and Water-Use Characteristics in the Vicinity of the Savannah River Site, Westinghouse Savannah River Company Report: WSRC-RP-9117, Aiken, SC, March 1991.

Hamby, D.M. 1992. Site-Specific Parameter Values for the Nuclear Regulatory Commission's Food Pathway Dose Model. Health Physics, 62:136. 1992. 
Hamby 1993a. Hamby, D. M., Westinghouse Soil Concentration Guidelines for the Savannah River Site Using the DOE/RESRAD Methodology, WSRC-TR-93-304. June 1993.

Hamby, D.M. 1993b. IRRIDOSE: An Electronic Spreadsheet Designed to Calculate Ingestion Dose Resulting from Irrigating with Savannah River Water. WSRC-RP-93-1174.

Hanford 2004. Exposure Scenarios and Unit Factors for the Hanford Tank Waste Performance Assessment, HNF-SD-WM-TI-707, Revision 4, June 2004.

ICRP 1974. Reference Man: Anatomical, Physiological And Metabolic Characteristics, ICRP Publication 23: Elmsford, NY, 1974.

IAEA 1994. International Atomic Energy Agency, Handbook of Parameter Values for the Prediction of Radionuclide Transfer in Temperate Environments. Technical Report series No. 364. 1994.

Idaho 2003. DOE/ID-10966, Performance Assessment for the Tank Farm Facility at the Idaho National Engineering and Environmental Laboratory, April 2003.

Jannik 2003. Jannik, G.T. Cesium-137 Bioconcentration Factor for Freshwater Fish in the SRS Environment. SRT-EST-2003-00134 Westinghouse Savannah River Company InterOffice Memorandum, July 15, 2003.

Jannik and Dixon 2006 Jannik, G.T. and Dixon, K.L., LADTAP-PA: A Spreadsheet for Estimating Dose Resulting from E-Area Groundwater Contamination at the Savannah River Site, WSRC-STI-2006-00123, Savannah River National Laboratory, Aiken, SC.

Kennedy and Strenge 1992. NUREG/CR-5512, PNL-7994, Kennedy \& Strenge, Residual Radioactive Contamination from Decommissioning.

Koffman, L. D. 2006a. SRNL All-Pathways Application. WSRC-STI-2006-000179, Savannah River National Laboratory, Aiken, SC

Koffman, L.D. 2006b. An Automated Inadvertent Intruder Analysis Application. WSRC-TR2004-00293. Westinghouse Savannah River Company, Aiken, SC

Lee 2001. Environmental Dose Assessment Manual. WSRC-IM-91-1, Rev 3. Westinghouse Savannah River Company, Aiken, South Carolina. July 2001.

Lee 2004. Lee, P. L., WSRC-TR-2004-00295, Inadvertent Intruder Analysis Input For Radiological Performance Assessments, Westinghouse Savannah River Company, Aiken, South Carolina, Revision 0, July 2004.

McDowell-Boyer et al. 2000. McDowell-Boyer, L., Yu, A.D., Cook, J.R., Kocher, D.C. Wilhite, E.L., Holmes-Burns, H., and Young, K.E. 2000. Radiological Performance Assessment for the E-Area Low-Level Waste Facility, WSRC-RP-94-218, Revision 0, Westinghouse Savannah River Company, Aiken, South Carolina. 2000. 
Napier et al. 1984. .Napier, B.A., R.A. Peloquin, W.E. Kennedy, Jr., and S.M. Neuder. Intruder Dose Pathway Analysis for Onsite Disposal for Radioactive Waste: THE ONSITE/MAXII Computer Program. NUREG/CR-3620, PNL-4054. Pacific Northwest Laboratory. 1984.

NCRP 1996. Screening Models for Releases of Radionuclides to Atmosphere, Surface Water, and Ground. NCRP Report No 123 Volume I. January 22, 1996.

NRC 1977. Regulatory Guide 1.109, Calculation of Annual Doses to Man from Routine Releases of Reactor Effluents for the Purpose of Evaluating Compliance with 10 CFR 50, Appendix I, Washington, DC.

NTS 1991. Performance Assessment/Composite Analysis for the Area 5 Radioactive Waste Management Site at the Nevada Test Site, Nye County, Nevada (Revision 2.1), DOE/NV/11718-176 UC-721, January 1998.

NTS 1998. Performance Assessment/Composite Analysis for the Area 5 Radioactive Waste Management Site at the Nevada Test Site, Nye County, Nevada (Revision 2.1), DOE/NV/11718-176 UC-721, January 1998.

NTS 2000. Performance Assessment/Composite Analysis for the Area 3 Radioactive Waste Management Site at the Nevada Test Site, Nye County, Nevada (Revision 2.1), DOE/NV-491-Rev2.1, October 2000.

NTS 2001. Compliance Assessment Document for the Transuranic Wastes in Greater Confinement Disposal Boreholes at the Nevada Test Site, Volume 2 Performance Assessment Version 2.0, SAND2001-2977, September 2001.

ORNL 1997, Performance Assessment for the Class L-II Disposal Facility, ORNL/TM-13401, March 1997.

Oztunali, et al. 1981. Oztunali, O.I., G.C. Re, P.M Moskowski, ed Picazo and C.J. Pitt. 1981 Database for Radioactive Waste Management. NUREG/CR-1759 Dames and Moore, Inc.

Sheppard and Thibault 1990. Sheppard, M.I., and D.H. Thibault. Default Soil Solid/Liquid Partition Coefficients, Kds, for Four Major Soil Types: A Compendium. Health Physics, 59: 471-482. 1990.

Staven et al. 2003. Staven, L.H.; Napier, B.A., Rhoads, K., Strenge, D.L. A Compendium of Transfer Factors for Agricultural and Animal Products. PNNL-13421 Pacific Northwest National Laboratory, June 2003.

Wikipedia 2006. Geometric mean from Wikipedia, the free encyclopedia http://en.wikipedia.org/wiki/Geometric_mean.

Yu et al. 1993. C. Yu, C. Loureiro*, J.-J. Cheng, L.G. Jones, Y.Y. Wang, Y.P. Chia,* and E. Faillace Data Collection Handbook To Support Modeling Impacts Of Radioactive Material In Soil. Environmental Assessment and Information Sciences Division. Argonne National Laboratory, Argonne, Illinois April 1993. 
Yu et al. 2001 C. Yu, A.J. Zielen, J.-J. Cheng, D.J. LePoire, E. Gnanapragasam, S. Kamboj, Arnish, A.Wallo III, W.A. Williams, and H. Peterson. Users Manual for RESRAD Version 6, Argonne National Laboratory Report: ANL/EAD/4, Argonne, IL. July, 2001. 


\section{APPENDIX A. PHYSICAL PARAMETERS AND CONSUMPTION RATES CONSIDERED}

Table A- 1. Crop Exposure Times and Productivity from the Other Sources

\begin{tabular}{|c|c|c|c|c|c|c|c|c|c|}
\hline Parameter & \multicolumn{2}{|c|}{ EPA 1997} & $\begin{array}{c}\text { RESRAD } \\
\text { (Yu et al. } \\
1993 \text { and } \\
2001 \text { ) }\end{array}$ & $\begin{array}{c}\text { NUREG/CR-5512 } \\
\text { (Kennedy and } \\
\text { Strenge 1992) }\end{array}$ & $\begin{array}{c}\text { RG } 1.109 \\
\text { (NRC 1977) }\end{array}$ & $\begin{array}{c}\text { Idaho } \\
2003\end{array}$ & $\begin{array}{c}\text { Hanford } \\
2004\end{array}$ & NTS 2000 & $\begin{array}{c}\text { ORNL } \\
1997\end{array}$ \\
\hline \multicolumn{10}{|l|}{ Exposure Time to Irrigation (d) } \\
\hline Pasture & & & & 90 & 30 & 90 & 292 & & \\
\hline Crop & & & & 90 & 60 & 90 & & & \\
\hline Soil (grass-cow-milk) & & & & & 5458 & $60-240$ & & & \\
\hline Soil (crop/veg) & & & & & 60 & $60-240$ & & & \\
\hline \multicolumn{10}{|l|}{ Productivity } \\
\hline Pasture grass $\left(\mathrm{kg} / \mathrm{m}^{2}\right)$ & & & & 1 & 0.7 & & 1.5 & & \\
\hline Agricultural (veg/produce) $\left(\mathrm{kg} / \mathrm{m}^{2}\right)$ & & & & 4 & 2 & & 0.5 & & \\
\hline Vegetable crop yield $\left(\mathrm{kg} / \mathrm{m}^{2}\right)$ & & & & 4 & & & 2 & & \\
\hline Fraction Produced Locally & All Pathways & Intruder & & & & & & & \\
\hline Vegetables & 0.173 & 0.308 & 0.5 & 0.25 & 0.76 & & & 0.2 & \\
\hline Leafy vegetables & 0.173 & 0.308 & 0.5 & & 1 & & & 0.2 & \\
\hline Beef & 0.306 & 0.319 & 1 & & & & & 0.4 & \\
\hline Milk & 0.207 & 0.254 & 1 & & & & & 0.4 & \\
\hline \multicolumn{10}{|c|}{ Dilution factor for mixing of waste with soil in vegetable garden } \\
\hline for agriculture scenario & & & & & & & & & 0.2 \\
\hline for post drilling scenario & & & & & & & & & 0.002 \\
\hline
\end{tabular}


Table A- 2. Physical Parameters from the Other Sources

\begin{tabular}{|c|c|c|c|c|c|c|c|}
\hline Parameter & $\begin{array}{c}\text { RESRAD (Yu et al. } \\
1993 \text { and 2001) }\end{array}$ & $\begin{array}{c}\text { NUREG/CR-5512 } \\
\text { (Kennedy and } \\
\text { Strenge 1992) } \\
\end{array}$ & $\begin{array}{c}\text { RG } 1.109 \\
\text { (NRC 1977) }\end{array}$ & Idaho 2003 & $\begin{array}{c}\text { HANFORD } \\
2004\end{array}$ & NTS 2000 & ORNL 1997 \\
\hline Areal density of soil $\left(\mathrm{kg} / \mathrm{m}^{2}\right)$ & & 240 & & & & & \\
\hline Soil Density $\left(\mathrm{kg} / \mathrm{m}^{3}\right)$ & & & & $1.60 \mathrm{E}+03$ & & $1.51 \mathrm{E}+03$ & $1.40 \mathrm{E}+03$ \\
\hline \multicolumn{8}{|l|}{ Atmospheric mass loading of soil $\left(\mathrm{kg} / \mathrm{m}^{3}\right)$} \\
\hline while working in garden & $2.00 \mathrm{E}-07$ & & & $1.0 \mathrm{E}-07$ & & & $1.00 \mathrm{E}-07$ \\
\hline while residing in home & $2.00 \mathrm{E}-07$ & & & & & $2.10 \mathrm{E}-08$ & $1.00 \mathrm{E}-08$ \\
\hline Depth of garden $(\mathrm{cm})$ & 15 & 15 & & 61 & 15 & & \\
\hline Garden irrigation rate $\left(\mathrm{L} / \mathrm{d} / \mathrm{m}^{2}\right)$ & 5.5 & 2.08 & & 8.47 & & & \\
\hline Fraction of the year that crops are irrigated & & & & 0.25 & & & \\
\hline Fractional retention of deposition on leaves & & & 0.25 & & & & \\
\hline Garden size $\left(\mathrm{m}^{2}\right)$ & & & & & 207.3 & & \\
\hline
\end{tabular}


Table A- 3. Consumption Rates from the Literature

\begin{tabular}{|c|c|c|c|c|c|c|c|c|c|}
\hline Parameter & $\begin{array}{l}\text { EPA } \\
1997\end{array}$ & $\begin{array}{c}\text { Yu et al } 1993 \\
\text { and } 2001\end{array}$ & $\begin{array}{l}\text { Kennedy and } \\
\text { Strenge } 1992\end{array}$ & $\begin{array}{l}\text { NRC } 1977 \\
\text { Average }\end{array}$ & $\begin{array}{c}\text { NRC } 1977 \\
\text { MEI }\end{array}$ & Idaho 2003 & $\begin{array}{c}\text { Hanford } \\
2004\end{array}$ & NTS 2000 & $\begin{array}{c}\text { ORNL } \\
1997 \\
\end{array}$ \\
\hline Breathing rate $\left(\mathrm{m}^{3} / \mathrm{yr}\right)$ & 5548 & 8400 & & 8000 & 8000 & 8400 & 5457 & $3,767-36,792$ & 8000 \\
\hline \multicolumn{10}{|l|}{ Consumption Rate } \\
\hline Soil (kg/yr) & 0.037 & 0.0365 & 0.05 & & & 0.4 & 0.015 & 0.018 & 0.037 \\
\hline Leafy vegetable $(\mathrm{kg} / \mathrm{yr})$ & 16.7 & 14 & 11 & 64 & 64 & 18 & 17.8 & 18 & \\
\hline Other vegetables (kg/yr) & 79.2 & 160 & 51 & $190^{\circ}$ & 520 & 176 & 172.3 & 73 & 90 \\
\hline Meat $(\mathrm{kg} / \mathrm{yr})$ & 26 & 63 & 59 & 95 & 110 & 85 & 27.4 & 31 & \\
\hline Finfish (kg/yr) & 2.2 & 5.4 & 10 & 6.9 & 21 & & 9.9 & & \\
\hline Seafood (kg/yr) & 4 & 0.9 & & 1 & 5 & & & & \\
\hline Milk (L/yr) & 73.7 & 92 & 100 & 110 & 310 & 112 & 110 & 95 & \\
\hline Water $(\mathrm{L} / \mathrm{y})$ & 507 & 510 & & 370 & 730 & 258 & 730 & 493 & 730 \\
\hline Fodder(beef cow) (kg/d) & & 68 & 27 & 50 & 50 & 12 & & 47 & \\
\hline Fodder $-($ milk cow $)(\mathrm{kg} / \mathrm{d})$ & & 55 & 36 & 50 & 50 & 16 & & 47 & \\
\hline Fraction of milk-cow intake from pasture & & 1 & & & & & & $4 \mathrm{E}-04$ & \\
\hline Fraction of beef-cow intake from pasture & & 1 & & & & & & $4 \mathrm{E}-04$ & \\
\hline Water (beef cow) (L/d) & & 50 & 50 & & & & 50 & & \\
\hline Water (milk cow) (L/d) & & 160 & 60 & & & & 60 & & \\
\hline \multicolumn{10}{|l|}{ Exposure Time } \\
\hline Shoreline (hrs/yr) & & & & 8.3 & 12 & & 11 & & \\
\hline Swimming (hrs/yr) & 12 & & & & & & 9.1 & & \\
\hline Boating ( hrs/yr) & & & & & & & 9.1 & & \\
\hline Showering $(\mathrm{min} / \mathrm{d})$ & 10 & & & & & & 15 & & \\
\hline Fraction of yr working in garden (/yr) & & 0.25 & 0.01 & & & & 0.14 & 0.01 & 0.01 \\
\hline Fraction of yr residing in home (/yr) & 0.7 & 0.5 & & & 0.5 & & & 0.3 & 0.5 \\
\hline Fraction of time cattle on pasture & & 1 & & & & & & & \\
\hline \multicolumn{10}{|l|}{ Transport (days) } \\
\hline Vegetables & & 14 & 14 & 14 & 14 & & & & \\
\hline Feed-milk-man transport time & & 1 & 1 & 2 & 4 & & & & \\
\hline Meat & & 20 & 20 & 20 & & & & & \\
\hline Drinking water & & 1 & & & & & & & \\
\hline
\end{tabular}


THIS PAGE INTENTIONALLY LEFT BLANK 


\section{APPENDIX B. COMPREHENSIVE BIOACCUMULATION FACTORS}

\section{Table B-1. Comprehensive Updated Soil-to-Vegetable Transfer Factors}

\begin{tabular}{|c|c|c|c|c|c|c|c|c|c|}
\hline \multirow[b]{2}{*}{$\mathbf{Z}$} & \multirow[b]{2}{*}{ Element } & \multicolumn{2}{|c|}{ Current Analyses } & \multicolumn{4}{|c|}{ Updated Soil-to-Vegetable Transfer Factors } & \multicolumn{2}{|c|}{$\begin{array}{c}\text { Update/Current Use } \\
\text { Ratio* }\end{array}$} \\
\hline & & Intruder & \begin{tabular}{|c|} 
All \\
Pathways \\
\end{tabular} & Updated Value & Reference & Min & Max & Intruder & \begin{tabular}{|c|} 
All \\
Pathways \\
\end{tabular} \\
\hline 89 & Ac & $1.50 \mathrm{E}-04$ & $2.50 \mathrm{E}-03$ & 6.83E-05 & PNNL-13421 & 6.69E-05 & $3.50 \mathrm{E}-03$ & 0.5 & 0.03 \\
\hline 47 & $\mathrm{Ag}$ & $4.28 \mathrm{E}-02$ & $1.50 \mathrm{E}-01$ & $1.18 \mathrm{E}-02^{\dagger}$ & PNNL-13421 & $2.54 \mathrm{E}-04$ & $1.50 \mathrm{E}-01$ & 0.006 & 0.002 \\
\hline 13 & $\mathrm{Al}$ & 2.78E-04 & $4.00 \mathrm{E}-03$ & $1.27 \mathrm{E}-04$ & ORNL-5786 & $1.24 \mathrm{E}-04$ & 4.00E-03 & 0.5 & 0.03 \\
\hline 95 & $\mathrm{Am}$ & 1.07E-04 & $2.50 \mathrm{E}-04$ & 6.83E-05 & PNNL-13421 & $1.10 \mathrm{E}-05$ & $1.70 \mathrm{E}-01$ & 0.6 & 0.3 \\
\hline 18 & $\mathrm{Ar}$ & 0 & & 0 & ORNL-5786 & 0 & 0 & NA & NA \\
\hline 33 & As & 2.57E-03 & & $1.17 \mathrm{E}-03$ & PNNL-13421 & 1.17E-03 & 8.00E-02 & 0.5 & NA \\
\hline 85 & At & 6.42E-02 & $2.00 \mathrm{E}-01$ & 2.93E-02 & ORNL-5786 & 2.87E-02 & $2.00 \mathrm{E}-01$ & 0.5 & 0.1 \\
\hline 79 & $\mathrm{Au}$ & $4.28 \mathrm{E}-02$ & $2.50 \mathrm{E}-04$ & $3.51 \mathrm{E}-03$ & PNNL-13421 & $2.50 \mathrm{E}-04$ & $1.00 \mathrm{E}-01$ & 0.1 & 14.0 \\
\hline 5 & $\mathrm{~B}$ & & & 3.90E-01 & ORNL-5786 & $1.00 \mathrm{E}-02$ & $4.00 \mathrm{E}+00$ & NA & NA \\
\hline 56 & $\mathrm{Ba}$ & $6.42 \mathrm{E}-03$ & & 2.93E-03 & PNNL-13421 & $2.87 \mathrm{E}-03$ & $4.00 \mathrm{E}-02$ & 0.5 & NA \\
\hline 4 & $\mathrm{Be}$ & $6.42 \mathrm{E}-04$ & $4.00 \mathrm{E}-03$ & 2.93E-04 & PNNL-13421 & $2.87 \mathrm{E}-04$ & $4.00 \mathrm{E}-03$ & 0.5 & 0.1 \\
\hline 83 & $\mathrm{Bi}$ & $2.14 \mathrm{E}-03$ & $1.00 \mathrm{E}-01$ & $9.75 \mathrm{E}-02$ & PNNL-13421 & $9.56 \mathrm{E}-04$ & $1.00 \mathrm{E}-01$ & 45.6 & 1.0 \\
\hline 97 & $\mathrm{Bk}$ & & 5.90E-05 & $1.00 \mathrm{E}-03$ & NCRP 123 & 5.90E-05 & $1.00 \mathrm{E}-03$ & NA & 16.9 \\
\hline 35 & $\mathrm{Br}$ & 6.42E-01 & & 2.93E-01 & PNNL-13421 & 2.93E-01 & 7.60E-01 & 0.5 & NA \\
\hline 6 & $\mathrm{C}$ & $5.60 \mathrm{E}-01$ & $5.50 \mathrm{E}+00$ & $1.37 \mathrm{E}-01$ & PNNL-13421 & $1.37 \mathrm{E}-01$ & $5.50 \mathrm{E}+00$ & 0.2 & 0.02 \\
\hline 20 & $\mathrm{Ca}$ & $1.50 \mathrm{E}-01$ & $5.00 \mathrm{E}-01$ & 6.83E-02 & PNNL-13421 & $6.69 \mathrm{E}-02$ & $5.00 \mathrm{E}-01$ & 0.5 & 0.1 \\
\hline 48 & $\mathrm{Cd}$ & 6.42E-02 & $3.00 \mathrm{E}-01$ & 2.93E-02 & PNNL-13421 & $2.87 \mathrm{E}-02$ & $5.00 \mathrm{E}-01$ & 0.5 & 0.1 \\
\hline 58 & $\mathrm{Ce}$ & $1.71 \mathrm{E}-03$ & & $3.90 \mathrm{E}-03$ & PNNL-13421 & 7.65E-04 & $3.00 \mathrm{E}-02$ & 2.3 & NA \\
\hline 98 & $\mathrm{Cf}$ & & $1.00 \mathrm{E}-03$ & 6.83E-05 & PNNL-13421 & $6.50 \mathrm{E}-06$ & $1.00 \mathrm{E}-02$ & NA & 0.1 \\
\hline 17 & $\mathrm{Cl}$ & $3.00 \mathrm{E}+01$ & $2.00 \mathrm{E}+01$ & $1.37 \mathrm{E}+01$ & PNNL-13421 & 3.00E-01 & $7.00 \mathrm{E}+01$ & 0.5 & 0.7 \\
\hline 96 & $\mathrm{Cm}$ & 6.42E-06 & $2.50 \mathrm{E}-03$ & 8.39E-05 & PNNL-13421 & $2.87 \mathrm{E}-06$ & $2.50 \mathrm{E}-03$ & 13.1 & 0.0 \\
\hline 27 & Co & $3.00 \mathrm{E}-03$ & $9.40 \mathrm{E}-03$ & $1.31 \mathrm{E}-02$ & PNNL-13421 & $1.34 \mathrm{E}-03$ & $1.20 \mathrm{E}+00$ & 4.4 & 1.4 \\
\hline 24 & $\mathrm{Cr}$ & 1.93E-03 & & 8.78E-04 & PNNL-13421 & $2.50 \mathrm{E}-04$ & $1.00 \mathrm{E}-02$ & 0.5 & NA \\
\hline 55 & Cs & $1.28 \mathrm{E}-02$ & $1.00 \mathrm{E}-02$ & $9.00 \mathrm{E}-01$ & $\begin{array}{c}\text { Friday et al. } \\
1996 \\
\end{array}$ & $1.10 \mathrm{E}-03$ & $9.00 \mathrm{E}-01$ & 70.1 & 90.0 \\
\hline 29 & $\mathrm{Cu}$ & 1.07E-01 & & $4.88 \mathrm{E}-02$ & PNNL-13421 & 4.88E-02 & $1.30 \mathrm{E}-01$ & 0.5 & NA \\
\hline 66 & Dy & $1.71 \mathrm{E}-03$ & & $3.90 \mathrm{E}-03$ & PNNL-13421 & $7.80 \mathrm{E}-04$ & $3.90 \mathrm{E}-03$ & 2.3 & NA \\
\hline 68 & Er & $1.71 \mathrm{E}-03$ & & 3.90E-03 & PNNL-13421 & 7.80E-04 & $3.90 \mathrm{E}-03$ & 2.3 & NA \\
\hline 99 & Es & & 5.90E-05 & $1.00 \mathrm{E}-03$ & NCRP 123 & 5.90E-05 & $1.00 \mathrm{E}-03$ & NA & 16.9 \\
\hline 63 & $\mathrm{Eu}$ & $1.71 \mathrm{E}-03$ & & $3.90 \mathrm{E}-03$ & PNNL-13421 & 7.65E-04 & $4.00 \mathrm{E}-03$ & 2.3 & NA \\
\hline 9 & $\mathrm{~F}$ & 2.57E-03 & & 1.17E-03 & PNNL-13421 & 1.17E-03 & $2.00 \mathrm{E}-02$ & 0.5 & NA \\
\hline 26 & $\mathrm{Fe}$ & 4.28E-04 & $6.60 \mathrm{E}-04$ & 9.75E-03 & PNNL-13421 & $1.91 \mathrm{E}-04$ & 9.75E-03 & 22.8 & 14.8 \\
\hline 100 & $\mathrm{Fm}$ & & & 2.00E-03 & NCRP 123 & $2.00 \mathrm{E}-03$ & $2.00 \mathrm{E}-03$ & NA & NA \\
\hline 87 & $\mathrm{Fr}$ & $1.28 \mathrm{E}-02$ & $3.00 \mathrm{E}-02$ & 5.85E-03 & ORNL-5786 & 5.73E-03 & $3.00 \mathrm{E}-02$ & 0.5 & 0.2 \\
\hline
\end{tabular}

*Values greater than two orders of magnitude from the currently used values (update/current ratio $>100$ or $<0.01$ ) are geometrically averaged to create the "updated value".

${ }^{\dagger}$ Geometric mean of PNNL-13421 site-specific value (2.54E-04) and currently used intruder and all pathways values. 
Table B-1. Comprehensive Updated Soil-to-Vegetable Transfer Factors (continued)

\begin{tabular}{|c|c|c|c|c|c|c|c|c|c|}
\hline \multirow[b]{2}{*}{$\mathbf{Z}$} & \multirow[b]{2}{*}{ Element } & \multicolumn{2}{|c|}{ Current Analyses } & \multicolumn{4}{|c|}{ Updated Soil-to-Vegetable Transfer Factors } & \multicolumn{2}{|c|}{$\begin{array}{c}\begin{array}{c}\text { Update/Current Use } \\
\text { Ratio* }\end{array} \\
\end{array}$} \\
\hline & & Intruder & \begin{tabular}{|c|} 
All \\
Pathways \\
\end{tabular} & Updated Value & Reference & Min & Max & Intruder & \begin{tabular}{|c|} 
All \\
Pathways \\
\end{tabular} \\
\hline 31 & $\mathrm{Ga}$ & $1.71 \mathrm{E}-04$ & 3.00E-03 & $7.80 \mathrm{E}-05$ & PNNL-13421 & 7.65E-05 & 3.00E-03 & 0.5 & 0.03 \\
\hline 64 & Gd & $1.71 \mathrm{E}-03$ & 2.00E-03 & 3.90E-03 & PNNL-13421 & 7.65E-04 & 4.00E-03 & 2.3 & 2.0 \\
\hline 32 & $\mathrm{Ge}$ & 3.42E-02 & $1.00 \mathrm{E}-01$ & $1.56 \mathrm{E}-02$ & ORNL-5786 & 1.53E-02 & 4.00E-01 & 0.5 & 0.2 \\
\hline 1 & $\mathrm{H}$ & $4.80 \mathrm{E}+00$ & & $4.80 \mathrm{E}+00$ & $\begin{array}{c}\text { Reg. Guide } \\
1.109 \\
\end{array}$ & 0 & $6.92 \mathrm{E}+00$ & - & NA \\
\hline 108 & На & & & 2.00E-03 & NCRP 123 & $2.00 \mathrm{E}-03$ & $2.00 \mathrm{E}-03$ & NA & NA \\
\hline 2 & $\mathrm{He}$ & & & 0 & NCRP 123 & 0 & 0 & NA & NA \\
\hline 72 & $\mathrm{Hf}$ & 3.64E-04 & $1.00 \mathrm{E}-04$ & 1.95E-04 & PNNL-13421 & $1.00 \mathrm{E}-04$ & $3.00 \mathrm{E}-03$ & 0.5 & 2.0 \\
\hline 80 & $\mathrm{Hg}$ & 8.56E-02 & 3.80E-01 & 3.90E-02 & PNNL-13421 & 3.82E-02 & $3.80 \mathrm{E}-01$ & 0.5 & 0.1 \\
\hline 67 & Ho & $1.71 \mathrm{E}-03$ & 2.50E-03 & 3.90E-03 & PNNL-13421 & 7.65E-04 & 4.00E-03 & 2.3 & 1.6 \\
\hline 53 & $\mathrm{I}$ & 2.14E-02 & 2.00E-02 & 7.80E-03 & PNNL-13421 & $3.40 \mathrm{E}-04$ & $5.00 \mathrm{E}-02$ & 0.4 & 0.4 \\
\hline 49 & In & & 3.00E-03 & $7.80 \mathrm{E}-05$ & PNNL-13421 & 7.65E-05 & 3.00E-03 & NA & 0.0 \\
\hline 77 & $\mathrm{Ir}$ & 6.42E-03 & 3.00E-02 & 2.93E-03 & PNNL-13421 & 2.87E-03 & $3.00 \mathrm{E}-02$ & 0.5 & 0.1 \\
\hline 19 & $\mathrm{~K}$ & 2.35E-01 & 3.00E-01 & $1.07 \mathrm{E}-01$ & PNNL-13421 & 1.05E-01 & $5.50 \mathrm{E}-01$ & 0.5 & 0.4 \\
\hline 36 & $\mathrm{Kr}$ & & & 0 & NCRP 123 & 0 & 0 & NA & NA \\
\hline 57 & $\mathrm{La}$ & $1.71 \mathrm{E}-03$ & $2.50 \mathrm{E}-03$ & 6.83E-05 & PNNL-13421 & 6.83E-05 & $2.50 \mathrm{E}-03$ & 0.04 & 0.03 \\
\hline 3 & $\mathrm{Li}$ & $1.71 \mathrm{E}-03$ & & 7.80E-04 & ORNL-5786 & 7.80E-04 & $1.71 \mathrm{E}-03$ & 0.5 & NA \\
\hline 103 & $\mathrm{Lr}$ & & & 2.00E-03 & NCRP 123 & $2.00 \mathrm{E}-03$ & $2.00 \mathrm{E}-03$ & NA & NA \\
\hline 71 & $\mathrm{Lu}$ & $1.71 \mathrm{E}-03$ & $2.50 \mathrm{E}-03$ & 7.80E-04 & ORNL-5786 & 7.65E-04 & $2.50 \mathrm{E}-03$ & 0.5 & 0.3 \\
\hline 101 & Md & & & 2.00E-03 & NCRP 123 & $2.00 \mathrm{E}-03$ & $2.00 \mathrm{E}-03$ & NA & NA \\
\hline 12 & $\mathrm{Mg}$ & 2.35E-01 & & 1.07E-01 & PNNL-13421 & $3.00 \mathrm{E}-02$ & 2.35E-01 & 0.5 & NA \\
\hline 25 & $\mathrm{Mn}$ & 2.14E-02 & 2.90E-02 & 3.90E-02 & PNNL-13421 & 9.56E-03 & $3.00 \mathrm{E}-01$ & 1.8 & 1.3 \\
\hline 42 & Mo & 2.57E-02 & $1.20 \mathrm{E}-01$ & $1.56 \mathrm{E}-01$ & PNNL-13421 & $1.15 \mathrm{E}-02$ & 8.00E-01 & 6.1 & 1.3 \\
\hline 7 & $\mathrm{~N}$ & $1.28 \mathrm{E}+01$ & & $3.50 \mathrm{E}-01^{*}$ & PNNL-13421 & $9.56 \mathrm{E}-03$ & $1.28 \mathrm{E}+01$ & 0.0007 & NA \\
\hline 11 & $\mathrm{Na}$ & 2.35E-02 & & 5.85E-02 & PNNL-13421 & 1.05E-02 & $3.00 \mathrm{E}-01$ & 2.5 & NA \\
\hline 41 & $\mathrm{Nb}$ & 2.14E-03 & 9.40E-03 & 4.88E-03 & PNNL-13421 & 9.56E-04 & $1.70 \mathrm{E}-02$ & 2.3 & 0.5 \\
\hline 60 & $\mathrm{Nd}$ & $1.71 \mathrm{E}-03$ & & 3.90E-03 & PNNL-13421 & 7.80E-04 & $3.90 \mathrm{E}-03$ & 2.3 & NA \\
\hline 10 & $\mathrm{Ne}$ & & & 0 & NCRP 123 & 0 & 0 & NA & NA \\
\hline 28 & $\mathrm{Ni}$ & 2.57E-02 & $1.90 \mathrm{E}-02$ & 1.17E-02 & PNNL-13421 & 1.15E-02 & $1.80 \mathrm{E}+00$ & 0.5 & 0.6 \\
\hline 102 & No & & & 2.00E-03 & NCRP 123 & $2.00 \mathrm{E}-03$ & $2.00 \mathrm{E}-03$ & NA & NA \\
\hline 93 & $\mathrm{~Np}$ & 4.28E-03 & 2.50E-03 & 2.54E-03 & PNNL-13421 & 7.10E-04 & $1.40 \mathrm{E}-01$ & 0.6 & 1.0 \\
\hline 8 & $\mathrm{O}$ & & & $6.00 \mathrm{E}-01$ & NCRP 123 & $6.00 \mathrm{E}-01$ & $6.00 \mathrm{E}-01$ & NA & NA \\
\hline 76 & Os & 1.50E-03 & & 6.83E-04 & PNNL-13421 & 6.83E-04 & $3.00 \mathrm{E}-02$ & 0.5 & NA \\
\hline 15 & $\mathrm{P}$ & $1.50 \mathrm{E}+00$ & $1.10 \mathrm{E}+00$ & 6.83E-01 & PNNL-13421 & 6.69E-01 & $3.50 \mathrm{E}+00$ & 0.5 & 0.6 \\
\hline 91 & $\mathrm{~Pa}$ & 1.07E-04 & $1.00 \mathrm{E}-02$ & 4.18E-04 ${ }^{\dagger}$ & PNNL-13421 & 4.78E-05 & $1.00 \mathrm{E}-02$ & 0.6 & 0.007 \\
\hline 82 & $\mathrm{~Pb}$ & 3.85E-03 & $1.00 \mathrm{E}-02$ & 1.17E-03 & PNNL-13421 & $1.30 \mathrm{E}-04$ & $1.30 \mathrm{E}-02$ & 0.3 & 0.1 \\
\hline 46 & $\mathrm{Pd}$ & 1.71E-02 & $1.00 \mathrm{E}-01$ & 7.80E-03 & PNNL-13421 & 7.65E-03 & $1.00 \mathrm{E}-01$ & 0.5 & 0.08 \\
\hline 61 & $\mathrm{Pm}$ & $1.71 \mathrm{E}-03$ & & 3.90E-03 & PNNL-13421 & 7.65E-04 & 4.00E-03 & 2.3 & NA \\
\hline 84 & Po & $1.71 \mathrm{E}-04$ & $1.00 \mathrm{E}-03$ & 1.37E-03 & PNNL-13421 & 7.65E-05 & $7.00 \mathrm{E}-03$ & 8.0 & 1.4 \\
\hline 59 & $\mathrm{Pr}$ & $1.71 \mathrm{E}-03$ & & 3.90E-03 & PNNL-13421 & 7.65E-04 & $3.90 \mathrm{E}-03$ & 2.3 & NA \\
\hline
\end{tabular}

${ }^{*}$ Geometric mean of PNNL-13421 site-specific value (9.56E-03) and currently used intruder and all pathways values.

${ }^{\dagger}$ Geometric mean of PNNL-13421 site-specific value (6.83E-05) and currently used intruder and all pathways values. 
Table B-1. Comprehensive Updated Soil-to-Vegetable Transfer Factors (continued)

\begin{tabular}{|c|c|c|c|c|c|c|c|c|c|}
\hline \multirow[b]{2}{*}{$\mathbf{Z}$} & \multirow[b]{2}{*}{ Element } & \multicolumn{2}{|c|}{ Current Analyses } & \multicolumn{4}{|c|}{ Updated Soil-to-Vegetable Transfer Factors } & \multicolumn{2}{|c|}{$\begin{array}{c}\text { Update/Current Use } \\
\text { Ratio* }^{*}\end{array}$} \\
\hline & & Intruder & \begin{tabular}{|c|} 
All \\
Pathways \\
\end{tabular} & Updated Value & Reference & Min & Max & Intruder & \begin{tabular}{|c|} 
All \\
Pathways \\
\end{tabular} \\
\hline 78 & Pt & 1.07E-02 & $2.40 \mathrm{E}-02$ & 4.88E-03 & ORNL-5786 & 4.78E-03 & $1.00 \mathrm{E}-01$ & 0.5 & 0.2 \\
\hline 94 & $\mathrm{Pu}$ & 1.93E-05 & $2.50 \mathrm{E}-04$ & 2.15E-04 & PNNL-13421 & 3.80E-06 & $5.60 \mathrm{E}-02$ & 11.1 & 0.9 \\
\hline 88 & $\mathrm{Ra}$ & $6.42 \mathrm{E}-03$ & 4.00E-02 & 4.64E-03* & PNNL-13421 & $3.90 \mathrm{E}-04$ & 5.50E-02 & 0.06 & 0.0098 \\
\hline 37 & $\mathrm{Rb}$ & $3.00 \mathrm{E}-02$ & $1.30 \mathrm{E}-01$ & $1.76 \mathrm{E}-01$ & PNNL-13421 & $1.34 \mathrm{E}-02$ & $9.00 \mathrm{E}-01$ & 5.9 & 1.4 \\
\hline 75 & $\mathrm{Re}$ & $1.50 \mathrm{E}-01$ & $2.10 \mathrm{E}+02$ & $1.29 \mathrm{E}+00^{\dagger}$ & PNNL-13421 & 6.83E-02 & $2.10 \mathrm{E}+02$ & 0.5 & 0.0003 \\
\hline 104 & $\mathrm{Rf}$ & & & 3.00E-03 & NCRP 123 & 3.00E-03 & $3.00 \mathrm{E}-03$ & NA & NA \\
\hline 45 & $\mathrm{Rh}$ & $1.71 \mathrm{E}-02$ & & 7.80E-03 & PNNL-13421 & 7.65E-03 & $1.30 \mathrm{E}+01$ & 0.5 & NA \\
\hline 86 & $\mathrm{Rn}$ & & & 0 & NUREG-5512 & 0 & 0 & NA & NA \\
\hline 44 & $\mathrm{Ru}$ & 8.56E-03 & $5.00 \mathrm{E}-02$ & 7.80E-03 & PNNL-13421 & $3.82 E-03$ & $5.00 \mathrm{E}-02$ & 0.9 & 0.2 \\
\hline 16 & S & 6.42E-01 & & 2.93E-01 & PNNL-13421 & 2.87E-01 & 6.42E-01 & 0.5 & NA \\
\hline 51 & $\mathrm{Sb}$ & $1.28 \mathrm{E}-02$ & $1.10 \mathrm{E}-02$ & $2.49 \mathrm{E}-03^{\ddagger}$ & PNNL-13421 & $1.09 \mathrm{E}-04$ & $1.30 \mathrm{E}-02$ & 0.009 & 0.01 \\
\hline 21 & Sc & 4.28E-04 & 2.00E-03 & $1.95 \mathrm{E}-04$ & PNNL-13421 & $1.91 \mathrm{E}-04$ & $2.00 \mathrm{E}-03$ & 0.5 & 0.1 \\
\hline 34 & Se & 1.07E-02 & $1.30 \mathrm{E}+00$ & $5.14 \mathrm{E}-02^{\S}$ & PNNL-13421 & $4.78 \mathrm{E}-03$ & $1.30 \mathrm{E}+00$ & 0.9 & 0.008 \\
\hline 14 & $\mathrm{Si}$ & 3.00E-02 & $8.80 \mathrm{E}-02$ & 1.37E-02 & PNNL-13421 & $1.34 \mathrm{E}-02$ & 8.80E-02 & 0.5 & 0.2 \\
\hline 62 & $\mathrm{Sm}$ & $1.71 \mathrm{E}-03$ & 2.50E-03 & 3.90E-03 & PNNL-13421 & 7.65E-04 & 4.00E-03 & 2.3 & 1.6 \\
\hline 50 & Sn & $2.57 \mathrm{E}-03$ & $2.50 \mathrm{E}-03$ & $1.17 \mathrm{E}-03$ & PNNL-13421 & $1.15 \mathrm{E}-03$ & 3.00E-01 & 0.5 & 0.5 \\
\hline 38 & $\mathrm{Sr}$ & 1.07E-01 & $1.70 \mathrm{E}-02$ & $9.75 \mathrm{E}-02$ & PNNL-13421 & $1.70 \mathrm{E}-02$ & $1.40 \mathrm{E}+01$ & 0.9 & 5.7 \\
\hline 73 & $\mathrm{Ta}$ & $1.07 \mathrm{E}-03$ & 2.50E-03 & 4.88E-03 & PNNL-13421 & 4.78E-04 & $2.00 \mathrm{E}-02$ & 4.6 & 2.0 \\
\hline 65 & $\mathrm{~Tb}$ & $1.71 \mathrm{E}-03$ & & 3.90E-03 & PNNL-13421 & $7.80 \mathrm{E}-04$ & $3.90 \mathrm{E}-03$ & 2.3 & NA \\
\hline 43 & Tc & 6.42E-01 & 2.50E-01 & 4.68E-02 & PNNL-13421 & 4.68E-02 & $5.46 \mathrm{E}+00$ & 0.07 & 0.2 \\
\hline 52 & $\mathrm{Te}$ & $1.71 \mathrm{E}-03$ & $1.30 \mathrm{E}+00$ & $1.20 \mathrm{E}-02^{* *}$ & PNNL-13421 & 7.65E-04 & $1.30 \mathrm{E}+00$ & 0.5 & 0.001 \\
\hline 90 & Th & 3.64E-05 & $4.20 \mathrm{E}-03$ & $6.44 \mathrm{E}-05$ & PNNL-13421 & $1.62 \mathrm{E}-05$ & $7.50 \mathrm{E}-03$ & 1.8 & 0.02 \\
\hline 22 & $\mathrm{Ti}$ & $1.28 \mathrm{E}-03$ & $1.00 \mathrm{E}-04$ & 5.85E-04 & ORNL-5786 & $1.00 \mathrm{E}-04$ & $3.00 \mathrm{E}-03$ & 0.5 & 5.9 \\
\hline 81 & $\mathrm{Tl}$ & $1.71 \mathrm{E}-04$ & $1.00 \mathrm{E}-04$ & 7.80E-05 & PNNL-13421 & 7.65E-05 & $2.00 \mathrm{E}-01$ & 0.5 & 0.8 \\
\hline 69 & $\mathrm{Tm}$ & $1.71 \mathrm{E}-03$ & & $7.80 \mathrm{E}-04$ & ORNL-5786 & $7.80 \mathrm{E}-04$ & $2.00 \mathrm{E}-03$ & 0.5 & NA \\
\hline 92 & $\mathrm{U}$ & $1.71 \mathrm{E}-03$ & $2.50 \mathrm{E}-03$ & $2.34 \mathrm{E}-03$ & PNNL-13421 & 7.65E-04 & $1.40 \mathrm{E}-01$ & 1.4 & 0.9 \\
\hline 23 & $\mathrm{~V}$ & $1.28 \mathrm{E}-03$ & $1.40 \mathrm{E}-03$ & 5.85E-04 & ORNL-5786 & 5.73E-04 & 3.00E-03 & 0.5 & 0.4 \\
\hline 74 & $\mathrm{~W}$ & $4.28 \mathrm{E}-03$ & & $5.00 \mathrm{E}-02^{\dagger \dagger}$ & PNNL-13421 & $1.91 \mathrm{E}-03$ & $8.00 \mathrm{E}-01$ & 136.7 & NA \\
\hline 54 & $\mathrm{Xe}$ & & & 0 & NUREG-5512 & 0 & 0 & NA & NA \\
\hline 39 & $\mathrm{Y}$ & 2.57E-03 & 2.60E-03 & $1.95 \mathrm{E}-03$ & PNNL-13421 & 1.15E-03 & $3.00 \mathrm{E}-01$ & 0.8 & 0.8 \\
\hline 70 & $\mathrm{Yb}$ & 1.71E-03 & & 7.80E-04 & ORNL-5786 & 7.80E-04 & $2.00 \mathrm{E}-03$ & 0.5 & NA \\
\hline 30 & $\mathrm{Zn}$ & 3.85E-01 & & 6.83E-02 & PNNL-13421 & 6.83E-02 & $2.34 \mathrm{E}+00$ & 0.2 & NA \\
\hline 40 & $\mathrm{Zr}$ & 2.14E-04 & $1.70 \mathrm{E}-04$ & 1.95E-04 & PNNL-13421 & $9.56 \mathrm{E}-05$ & $1.00 \mathrm{E}-03$ & 0.9 & 1.1 \\
\hline
\end{tabular}

\footnotetext{
*Geometric mean of PNNL-13421 site-specific value (3.90E-04) and currently used intruder and all pathways values. ${ }^{\dagger}$ Geometric mean of PNNL-13421 site-specific value (6.83E-02) and currently used intruder and all pathways values. ${ }^{\ddagger}$ Geometric mean of PNNL-13421 site-specific value (1.09E-04) and currently used intruder and all pathways values. ${ }^{\S}$ Geometric mean of PNNL-13421 site-specific value (9.75E-03) and currently used intruder and all pathways values.

${ }^{* *}$ Geometric mean of PNNL-13421 site-specific value (7.80E-04) and currently used intruder and all pathways values.

${ }^{\dagger \dagger}$ Geometric mean of PNNL-13421 site-specific value (5.85E-01) and currently used intruder and all pathways values.
} 
Table B- 2. Comprehensive Updated Feed-to-Milk Transfer Factors (d/L)

\begin{tabular}{|c|c|c|c|c|c|c|c|}
\hline \multirow[b]{2}{*}{$\mathbf{Z}$} & \multirow[b]{2}{*}{ Element } & \multirow[b]{2}{*}{$\begin{array}{c}\text { Current } \\
\text { Analyses }\end{array}$} & \multicolumn{4}{|c|}{ Updated Feed-to-Milk Transfer Factors } & \multirow[b]{2}{*}{$\begin{array}{c}\text { Update/Current } \\
\text { Use Ratio }\end{array}$} \\
\hline & & & $\begin{array}{c}\text { Updated } \\
\text { Factor }\end{array}$ & Reference & Min & Max & \\
\hline 89 & Ac & $2.00 \mathrm{E}-05$ & $2.00 \mathrm{E}-05$ & PNNL-13421 & $2.00 \mathrm{E}-06$ & 2.06E-05 & 1.0 \\
\hline 47 & $\mathrm{Ag}$ & $5.00 \mathrm{E}-02$ & $1.58 \mathrm{E}-03^{\dagger}$ & PNNL-13421 & $5.00 \mathrm{E}-05$ & $5.00 \mathrm{E}-02$ & 0.001 \\
\hline 13 & $\mathrm{Al}$ & $2.00 \mathrm{E}-04$ & $2.06 \mathrm{E}-04$ & ORNL-5786 & $2.00 \mathrm{E}-04$ & $2.06 \mathrm{E}-04$ & 1.0 \\
\hline 95 & $\mathrm{Am}$ & $5.00 \mathrm{E}-06$ & $1.50 \mathrm{E}-06$ & PNNL-13421 & 4.00E-07 & $5.00 \mathrm{E}-06$ & 0.3 \\
\hline 33 & As & & $6.00 \mathrm{E}-05$ & PNNL-13421 & $6.00 \mathrm{E}-05$ & $1.00 \mathrm{E}-04$ & NA \\
\hline 85 & At & $1.00 \mathrm{E}-02$ & 1.03E-02 & ORNL-5786 & $1.00 \mathrm{E}-02$ & 1.03E-02 & 1.0 \\
\hline 79 & $\mathrm{Au}$ & $5.00 \mathrm{E}-06$ & 5.50E-06 & PNNL-13421 & $5.00 \mathrm{E}-06$ & $1.00 \mathrm{E}-05$ & 1.1 \\
\hline 5 & $\mathrm{~B}$ & & $1.55 \mathrm{E}-03$ & ORNL-5786 & $1.50 \mathrm{E}-03$ & 3.00E-03 & NA \\
\hline 56 & $\mathrm{Ba}$ & & $4.80 \mathrm{E}-04$ & PNNL-13421 & 3.50E-04 & $8.00 \mathrm{E}-03$ & NA \\
\hline 4 & $\mathrm{Be}$ & 2.00E-06 & $9.00 \mathrm{E}-07$ & PNNL-13421 & $9.00 \mathrm{E}-07$ & $2.00 \mathrm{E}-06$ & 0.5 \\
\hline 83 & $\mathrm{Bi}$ & 5.00E-04 & $5.00 \mathrm{E}-04$ & PNNL-13421 & $5.00 \mathrm{E}-04$ & $1.00 \mathrm{E}-03$ & 1.0 \\
\hline 97 & $\mathrm{Bk}$ & $4.00 \mathrm{E}-07$ & $2.00 \mathrm{E}-06$ & NCRP 1996 & $4.00 \mathrm{E}-07$ & $2.00 \mathrm{E}-06$ & 5.0 \\
\hline 35 & $\mathrm{Br}$ & & $2.00 \mathrm{E}-02$ & PNNL-13421 & $2.00 \mathrm{E}-02$ & 2.06E-02 & NA \\
\hline 6 & $\mathrm{C}$ & $1.20 \mathrm{E}-02$ & $1.20 \mathrm{E}-02$ & Reg. Guide 1.109 & 1.05E-02 & $1.20 \mathrm{E}-02$ & 1.0 \\
\hline 20 & $\mathrm{Ca}$ & $3.00 \mathrm{E}-03$ & $3.00 \mathrm{E}-03$ & PNNL-13421 & $3.00 \mathrm{E}-03$ & 1.03E-02 & 1.0 \\
\hline 48 & $\mathrm{Cd}$ & $1.20 \mathrm{E}-04$ & $1.00 \mathrm{E}-03$ & PNNL-13421 & $1.20 \mathrm{E}-04$ & $2.00 \mathrm{E}-03$ & 8.3 \\
\hline 58 & $\mathrm{Ce}$ & & $3.00 \mathrm{E}-05$ & PNNL-13421 & $2.00 \mathrm{E}-05$ & $1.00 \mathrm{E}-04$ & NA \\
\hline 98 & $\mathrm{Cf}$ & $7.50 \mathrm{E}-07$ & $1.50 \mathrm{E}-06$ & PNNL-13421 & $7.50 \mathrm{E}-07$ & $2.00 \mathrm{E}-06$ & 2.0 \\
\hline 17 & $\mathrm{Cl}$ & 2.00E-02 & $1.70 \mathrm{E}-02$ & PNNL-13421 & $1.50 \mathrm{E}-02$ & $2.00 \mathrm{E}-02$ & 0.9 \\
\hline 96 & $\mathrm{Cm}$ & $5.00 \mathrm{E}-06$ & $2.00 \mathrm{E}-05$ & PNNL-13421 & $2.00 \mathrm{E}-06$ & 2.06E-05 & 4.0 \\
\hline 27 & Co & $1.00 \mathrm{E}-03$ & $3.00 \mathrm{E}-04$ & PNNL-13421 & $3.00 \mathrm{E}-04$ & 2.06E-03 & 0.3 \\
\hline 24 & $\mathrm{Cr}$ & & $1.00 \mathrm{E}-05$ & PNNL-13421 & $1.00 \mathrm{E}-05$ & $2.20 \mathrm{E}-03$ & NA \\
\hline 55 & Cs & $1.20 \mathrm{E}-02$ & $7.90 \mathrm{E}-03$ & PNNL-13421 & $7.00 \mathrm{E}-03$ & $1.20 \mathrm{E}-02$ & 0.7 \\
\hline 29 & $\mathrm{Cu}$ & & $2.00 \mathrm{E}-03$ & PNNL-13421 & $1.50 \mathrm{E}-03$ & $1.40 \mathrm{E}-02$ & NA \\
\hline 66 & Dy & & $3.00 \mathrm{E}-05$ & PNNL-13421 & $2.00 \mathrm{E}-05$ & $6.00 \mathrm{E}-05$ & NA \\
\hline 68 & Er & & $3.00 \mathrm{E}-05$ & PNNL-13421 & $2.00 \mathrm{E}-05$ & $6.00 \mathrm{E}-05$ & NA \\
\hline 99 & Es & $4.00 \mathrm{E}-07$ & $2.00 \mathrm{E}-06$ & NCRP 1996 & $4.00 \mathrm{E}-07$ & $2.00 \mathrm{E}-06$ & 5.0 \\
\hline 63 & $\mathrm{Eu}$ & & $3.00 \mathrm{E}-05$ & PNNL-13421 & $2.00 \mathrm{E}-05$ & $6.00 \mathrm{E}-05$ & NA \\
\hline 9 & $\mathrm{~F}$ & & $1.00 \mathrm{E}-03$ & PNNL-13421 & $1.00 \mathrm{E}-03$ & $7.00 \mathrm{E}-03$ & NA \\
\hline 26 & $\mathrm{Fe}$ & $1.20 \mathrm{E}-03$ & $3.00 \mathrm{E}-05$ & PNNL-13421 & $3.00 \mathrm{E}-05$ & $1.20 \mathrm{E}-03$ & 0.03 \\
\hline 87 & $\mathrm{Fr}$ & 8.00E-03 & 2.06E-02 & ORNL-5786 & 8.00E-03 & $2.06 \mathrm{E}-02$ & 2.6 \\
\hline 31 & $\mathrm{Ga}$ & $1.00 \mathrm{E}-05$ & $5.00 \mathrm{E}-05$ & PNNL-13421 & $1.00 \mathrm{E}-05$ & 5.15E-05 & 5.0 \\
\hline 64 & Gd & $6.00 \mathrm{E}-05$ & $3.00 \mathrm{E}-05$ & PNNL-13421 & $2.00 \mathrm{E}-05$ & $6.00 \mathrm{E}-05$ & 0.5 \\
\hline 32 & $\mathrm{Ge}$ & $7.00 \mathrm{E}-02$ & $7.21 \mathrm{E}-02$ & ORNL-5786 & $1.00 \mathrm{E}-02$ & $7.21 \mathrm{E}-02$ & 1.0 \\
\hline 1 & $\mathrm{H}$ & & $1.50 \mathrm{E}-02$ & PNNL-13421 & 0 & $1.50 \mathrm{E}-02$ & NA \\
\hline 105 & $\mathrm{Ha}$ & & $5.00 \mathrm{E}-06$ & NCRP 1996 & 5.00E-06 & $5.00 \mathrm{E}-06$ & NA \\
\hline
\end{tabular}

\footnotetext{
*Values greater than two orders of magnitude from the currently used values (update/current ratio $>100$ or $<0.01$ ) are geometrically averaged to create the "updated value".

${ }^{\dagger}$ Geometric mean of PNNL-13421 site-specific value (5.00E-05) and currently used value.
} 
Table B- 2. Comprehensive Updated Feed-to-Milk Transfer Factors (d/L) (continued)

\begin{tabular}{|c|c|c|c|c|c|c|c|}
\hline \multirow[b]{2}{*}{$\mathbf{Z}$} & \multirow[b]{2}{*}{ Element } & \multirow[b]{2}{*}{$\begin{array}{c}\text { Current } \\
\text { Analyses }\end{array}$} & \multicolumn{4}{|c|}{ Updated Feed-to-Milk Transfer Factors } & \multirow[b]{2}{*}{$\begin{array}{c}\text { Update/Current } \\
\text { Use Ratio }\end{array}$} \\
\hline & & & $\begin{array}{c}\text { Updated } \\
\text { Factor }\end{array}$ & Reference & Min & Max & \\
\hline 2 & $\mathrm{He}$ & & 0 & NCRP 1996 & 0 & 0 & NA \\
\hline 72 & Hf & $5.50 \mathrm{E}-07$ & 5.50E-07 & PNNL-13421 & $5.50 \mathrm{E}-07$ & $2.50 \mathrm{E}-05$ & 1.0 \\
\hline 80 & $\mathrm{Hg}$ & $5.00 \mathrm{E}-04$ & 4.70E-04 & PNNL-13421 & $4.50 \mathrm{E}-04$ & $5.00 \mathrm{E}-04$ & 0.9 \\
\hline 67 & Ho & $2.00 \mathrm{E}-05$ & $3.00 \mathrm{E}-05$ & PNNL-13421 & 2.00E-05 & $6.00 \mathrm{E}-05$ & 1.5 \\
\hline 53 & $\mathrm{I}$ & $6.00 \mathrm{E}-03$ & $9.00 \mathrm{E}-03$ & PNNL-13421 & $6.00 \mathrm{E}-03$ & $1.20 \mathrm{E}-02$ & 1.5 \\
\hline 49 & In & $2.00 \mathrm{E}-04$ & 2.00E-04 & PNNL-13421 & $1.00 \mathrm{E}-04$ & $2.00 \mathrm{E}-04$ & 1.0 \\
\hline 77 & Ir & $2.00 \mathrm{E}-06$ & $2.00 \mathrm{E}-06$ & PNNL-13421 & $2.00 \mathrm{E}-06$ & $2.06 \mathrm{E}-06$ & 1.0 \\
\hline 19 & $\mathrm{~K}$ & $7.00 \mathrm{E}-03$ & $7.20 \mathrm{E}-03$ & PNNL-13421 & $7.00 \mathrm{E}-03$ & $7.21 \mathrm{E}-03$ & 1.0 \\
\hline 57 & $\mathrm{La}$ & $5.00 \mathrm{E}-06$ & $2.00 \mathrm{E}-05$ & PNNL-13421 & $5.00 \mathrm{E}-06$ & $6.00 \mathrm{E}-05$ & 4.0 \\
\hline 3 & $\mathrm{Li}$ & & 2.06E-02 & ORNL-5786 & $2.06 \mathrm{E}-02$ & $5.00 \mathrm{E}-02$ & NA \\
\hline 103 & $\mathrm{Lr}$ & & $5.00 \mathrm{E}-06$ & NCRP 1996 & $5.00 \mathrm{E}-06$ & $5.00 \mathrm{E}-06$ & NA \\
\hline 71 & $\mathrm{Lu}$ & $2.00 \mathrm{E}-05$ & 2.06E-05 & ORNL-5786 & $2.00 \mathrm{E}-05$ & $6.00 \mathrm{E}-05$ & 1.0 \\
\hline 101 & Md & & $5.00 \mathrm{E}-06$ & NCRP 1996 & $5.00 \mathrm{E}-06$ & $5.00 \mathrm{E}-06$ & NA \\
\hline 12 & $\mathrm{Mg}$ & & 3.90E-03 & PNNL-13421 & $3.90 \mathrm{E}-03$ & 8.00E-03 & NA \\
\hline 25 & Mn & $2.50 \mathrm{E}-04$ & 3.00E-05 & PNNL-13421 & 3.00E-05 & $3.61 \mathrm{E}-04$ & 0.1 \\
\hline 42 & Mo & 7.50E-03 & $1.70 \mathrm{E}-03$ & PNNL-13421 & $1.50 \mathrm{E}-03$ & $7.50 \mathrm{E}-03$ & 0.2 \\
\hline 7 & $\mathrm{~N}$ & & $2.50 \mathrm{E}-02$ & PNNL-13421 & $1.00 \mathrm{E}-02$ & 2.58E-02 & NA \\
\hline 11 & $\mathrm{Na}$ & & $1.60 \mathrm{E}-02$ & PNNL-13421 & $1.60 \mathrm{E}-02$ & 4.00E-02 & NA \\
\hline 41 & $\mathrm{Nb}$ & $2.50 \mathrm{E}-03$ & $3.20 \mathrm{E}-05^{*}$ & PNNL-13421 & $4.10 \mathrm{E}-07$ & 2.06E-02 & 0.0002 \\
\hline 60 & $\mathrm{Nd}$ & & 3.00E-05 & PNNL-13421 & $5.00 \mathrm{E}-06$ & $6.00 \mathrm{E}-05$ & NA \\
\hline 28 & $\mathrm{Ni}$ & 6.70E-03 & $1.60 \mathrm{E}-02$ & PNNL-13421 & $1.00 \mathrm{E}-03$ & $2.00 \mathrm{E}-02$ & 2.4 \\
\hline 102 & No & & 5.00E-06 & NCRP 1996 & $5.00 \mathrm{E}-06$ & $5.00 \mathrm{E}-06$ & NA \\
\hline 93 & $\mathrm{~Np}$ & $5.00 \mathrm{E}-06$ & 5.00E-06 & PNNL-13421 & $5.00 \mathrm{E}-06$ & $1.00 \mathrm{E}-05$ & 1.0 \\
\hline 76 & Os & & $5.00 \mathrm{E}-03$ & PNNL-13421 & $1.00 \mathrm{E}-04$ & $3.50 \mathrm{E}+00$ & NA \\
\hline 15 & $\mathrm{P}$ & $2.50 \mathrm{E}-02$ & $1.60 \mathrm{E}-02$ & PNNL-13421 & $1.50 \mathrm{E}-02$ & $2.50 \mathrm{E}-02$ & 0.6 \\
\hline 91 & $\mathrm{~Pa}$ & $5.00 \mathrm{E}-06$ & 5.00E-06 & PNNL-13421 & $5.00 \mathrm{E}-06$ & 5.15E-06 & 1.0 \\
\hline 82 & $\mathrm{~Pb}$ & $3.00 \mathrm{E}-04$ & $2.60 \mathrm{E}-04$ & PNNL-13421 & $2.50 \mathrm{E}-04$ & $3.00 \mathrm{E}-04$ & 0.9 \\
\hline 46 & $\mathrm{Pd}$ & $5.00 \mathrm{E}-03$ & $1.00 \mathrm{E}-02$ & PNNL-13421 & $1.00 \mathrm{E}-04$ & 1.03E-02 & 2.0 \\
\hline 61 & $\mathrm{Pm}$ & & $3.00 \mathrm{E}-05$ & PNNL-13421 & $2.00 \mathrm{E}-05$ & $6.00 \mathrm{E}-05$ & NA \\
\hline 84 & Po & $3.40 \mathrm{E}-04$ & $3.40 \mathrm{E}-04$ & PNNL-13421 & $3.40 \mathrm{E}-04$ & $4.00 \mathrm{E}-04$ & 1.0 \\
\hline 59 & $\operatorname{Pr}$ & & $3.00 \mathrm{E}-05$ & PNNL-13421 & $5.00 \mathrm{E}-06$ & $6.00 \mathrm{E}-05$ & NA \\
\hline 78 & $\mathrm{Pt}$ & $5.00 \mathrm{E}-03$ & 5.15E-03 & ORNL-5786 & $1.00 \mathrm{E}-04$ & $5.15 \mathrm{E}-03$ & 1.0 \\
\hline 94 & $\mathrm{Pu}$ & $2.00 \mathrm{E}-06$ & $1.10 \mathrm{E}-06$ & PNNL-13421 & $1.00 \mathrm{E}-07$ & $2.00 \mathrm{E}-06$ & 0.6 \\
\hline 88 & $\mathrm{Ra}$ & $1.00 \mathrm{E}-03$ & $1.30 \mathrm{E}-03$ & PNNL-13421 & $4.50 \mathrm{E}-04$ & $1.30 \mathrm{E}-03$ & 1.3 \\
\hline 37 & $\mathrm{Rb}$ & $3.00 \mathrm{E}-02$ & $1.20 \mathrm{E}-02$ & PNNL-13421 & $1.00 \mathrm{E}-02$ & $3.00 \mathrm{E}-02$ & 0.4 \\
\hline 75 & $\mathrm{Re}$ & $1.40 \mathrm{E}-04$ & $1.50 \mathrm{E}-03$ & PNNL-13421 & $1.40 \mathrm{E}-04$ & $2.00 \mathrm{E}-03$ & 10.7 \\
\hline 104 & $\mathrm{Rf}$ & & $2.00 \mathrm{E}-05$ & NCRP 1996 & $2.00 \mathrm{E}-05$ & $2.00 \mathrm{E}-05$ & NA \\
\hline 45 & $\mathrm{Rh}$ & & $1.00 \mathrm{E}-02$ & PNNL-13421 & $5.00 \mathrm{E}-04$ & 1.03E-02 & NA \\
\hline 86 & $\mathrm{Rn}$ & & 0 & NCRP 1996 & 0 & 0 & NA \\
\hline 44 & $\mathrm{Ru}$ & $1.00 \mathrm{E}-06$ & 3.30E-06 & PNNL-13421 & $6.00 \mathrm{E}-07$ & $2.00 \mathrm{E}-05$ & 3.3 \\
\hline
\end{tabular}

\footnotetext{
*Geometric mean of PNNL-13421 site-specific value (4.10E-07) and currently used value.
} 
Table B- 2. Comprehensive Updated Feed-to-Milk Transfer Factors (d/L) (continued)

\begin{tabular}{|c|c|c|c|c|c|c|c|}
\hline \multirow[b]{2}{*}{$\mathbf{Z}$} & \multirow[b]{2}{*}{ Element } & \multirow[b]{2}{*}{$\begin{array}{l}\text { Current } \\
\text { Analyses }\end{array}$} & \multicolumn{4}{|c|}{ Updated Feed-to-Milk Transfer Factors } & \multirow[b]{2}{*}{$\begin{array}{c}\text { Update/Current } \\
\text { Use Ratio }\end{array}$} \\
\hline & & & $\begin{array}{c}\text { Updated } \\
\text { Factor }\end{array}$ & Reference & Min & Max & \\
\hline 16 & $\mathrm{~S}$ & & $1.60 \mathrm{E}-02$ & PNNL-13421 & $1.50 \mathrm{E}-02$ & 2.00E-02 & NA \\
\hline 51 & $\mathrm{Sb}$ & $1.50 \mathrm{E}-03$ & $2.50 \mathrm{E}-05$ & PNNL-13421 & $2.50 \mathrm{E}-05$ & $1.50 \mathrm{E}-03$ & 0.02 \\
\hline 21 & Sc & $6.00 \mathrm{E}-05$ & $5.00 \mathrm{E}-06$ & PNNL-13421 & $5.00 \mathrm{E}-06$ & $6.00 \mathrm{E}-05$ & 0.08 \\
\hline 34 & Se & $4.50 \mathrm{E}-02$ & 4.00E-03 & PNNL-13421 & 4.00E-03 & $4.50 \mathrm{E}-02$ & 0.09 \\
\hline 14 & $\mathrm{Si}$ & $2.00 \mathrm{E}-05$ & 2.00E-05 & PNNL-13421 & 2.00E-05 & 2.06E-05 & 1.0 \\
\hline 62 & Sm & $5.00 \mathrm{E}-06$ & 3.00E-05 & PNNL-13421 & $5.00 \mathrm{E}-06$ & $6.00 \mathrm{E}-05$ & 6.0 \\
\hline 50 & Sn & $2.50 \mathrm{E}-03$ & $1.00 \mathrm{E}-03$ & PNNL-13421 & $1.00 \mathrm{E}-03$ & $2.50 \mathrm{E}-03$ & 0.4 \\
\hline 38 & $\mathrm{Sr}$ & 8.00E-04 & $2.80 \mathrm{E}-03$ & PNNL-13421 & 8.00E-04 & $2.80 \mathrm{E}-03$ & 3.5 \\
\hline 73 & $\mathrm{Ta}$ & $3.00 \mathrm{E}-06$ & 4.10E-07 & PNNL-13421 & $4.10 \mathrm{E}-07$ & $5.00 \mathrm{E}-06$ & 0.1 \\
\hline 65 & $\mathrm{~Tb}$ & & $3.00 \mathrm{E}-05$ & PNNL-13421 & $2.00 \mathrm{E}-05$ & $6.00 \mathrm{E}-05$ & NA \\
\hline 43 & Tc & $2.50 \mathrm{E}-02$ & $1.87 \mathrm{E}-03^{*}$ & PNNL-13421 & 2.30E-05 & 2.50E-02 & 0.006 \\
\hline 52 & $\mathrm{Te}$ & $1.00 \mathrm{E}-03$ & 4.50E-04 & PNNL-13421 & $2.00 \mathrm{E}-04$ & $1.00 \mathrm{E}-03$ & 0.5 \\
\hline 90 & Th & $5.00 \mathrm{E}-06$ & $5.00 \mathrm{E}-06$ & PNNL-13421 & $5.00 \mathrm{E}-06$ & 5.15E-06 & 1.0 \\
\hline 22 & $\mathrm{Ti}$ & 5.50E-07 & $7.53 \mathrm{E}-05^{\dagger}$ & ORNL-5786 & $5.50 \mathrm{E}-07$ & $1.03 \mathrm{E}-02$ & 18,727 \\
\hline 81 & $\mathrm{Tl}$ & $1.00 \mathrm{E}-02$ & $2.00 \mathrm{E}-03$ & PNNL-13421 & $1.00 \mathrm{E}-03$ & $1.00 \mathrm{E}-02$ & 0.2 \\
\hline 69 & $\mathrm{Tm}$ & & 2.06E-05 & ORNL-5786 & 2.06E-05 & $6.00 \mathrm{E}-05$ & NA \\
\hline 92 & $\mathrm{U}$ & $5.00 \mathrm{E}-04$ & 4.00E-04 & PNNL-13421 & $4.00 \mathrm{E}-04$ & $6.18 \mathrm{E}-04$ & 0.8 \\
\hline 23 & $\mathrm{~V}$ & $2.00 \mathrm{E}-05$ & 2.06E-05 & ORNL-5786 & $2.00 \mathrm{E}-05$ & $5.00 \mathrm{E}-04$ & 1.0 \\
\hline 74 & $\mathrm{~W}$ & & 3.00E-04 & PNNL-13421 & 3.00E-04 & 5.00E-04 & NA \\
\hline 39 & $\mathrm{Y}$ & $1.00 \mathrm{E}-05$ & $2.00 \mathrm{E}-05$ & PNNL-13421 & $1.00 \mathrm{E}-05$ & $2.00 \mathrm{E}-03$ & 2.0 \\
\hline 70 & $\mathrm{Yb}$ & & 2.06E-05 & ORNL-5786 & 2.06E-05 & $6.00 \mathrm{E}-05$ & NA \\
\hline 30 & $\mathrm{Zn}$ & & $1.00 \mathrm{E}-02$ & PNNL-13421 & $1.00 \mathrm{E}-02$ & 3.90E-02 & NA \\
\hline 40 & $\mathrm{Zr}$ & $5.00 \mathrm{E}-06$ & $5.50 \mathrm{E}-07$ & PNNL-13421 & $5.50 \mathrm{E}-07$ & 3.09E-05 & 0.1 \\
\hline
\end{tabular}

* Geometric mean of PNNL-13421 site-specific value (1.40E-04) and currently used value.

${ }^{\dagger}$ Geometric mean of ORNL-5786 site-specific value (1.03E-02) and currently used value. 
Table B- 3. Comprehensive Updated Feed-to-Meat Bioaccumulation Factors (d/kg)

\begin{tabular}{|c|c|c|c|c|c|c|c|}
\hline \multirow[b]{2}{*}{$\mathbf{Z}$} & \multirow[b]{2}{*}{ Element } & \multirow{2}{*}{$\begin{array}{c}\text { Current SRS } \\
\text { Value }\end{array}$} & \multicolumn{4}{|c|}{ Updated Feed-to-Meat Transfer Factors } & \multirow{2}{*}{$\begin{array}{l}\text { Update/Current } \\
\text { Use Ratio* }\end{array}$} \\
\hline & & & Updated Value & Reference & Min & Max & \\
\hline 89 & Ac & $2.0 \mathrm{E}-05$ & $4.00 \mathrm{E}-04$ & PNNL-13421 & $2.00 \mathrm{E}-05$ & $4.00 \mathrm{E}-04$ & 20.0 \\
\hline 47 & $\mathrm{Ag}$ & $1.7 \mathrm{E}-02$ & $3.00 \mathrm{E}-03$ & PNNL-13421 & $3.00 \mathrm{E}-03$ & $1.70 \mathrm{E}-02$ & 0.2 \\
\hline 13 & $\mathrm{Al}$ & $5.0 \mathrm{E}-04$ & $1.50 \mathrm{E}-03$ & ORNL-5786 & $5.00 \mathrm{E}-04$ & $1.50 \mathrm{E}-03$ & 3.0 \\
\hline 95 & Am & $2.0 \mathrm{E}-04$ & $4.00 \mathrm{E}-05$ & PNNL-13421 & $3.50 \mathrm{E}-06$ & $2.00 \mathrm{E}-04$ & 0.2 \\
\hline 33 & As & & 2.00E-03 & PNNL-13421 & $1.50 \mathrm{E}-03$ & 2.00E-02 & NA \\
\hline 85 & At & $1.0 \mathrm{E}-02$ & $1.00 \mathrm{E}-02$ & ORNL-5786 & $1.00 \mathrm{E}-02$ & $1.00 \mathrm{E}-02$ & 1.0 \\
\hline 79 & $\mathrm{Au}$ & $2.0 \mathrm{E}-04$ & $5.00 \mathrm{E}-03$ & PNNL-13421 & $2.00 \mathrm{E}-04$ & $8.00 \mathrm{E}-03$ & 25.0 \\
\hline 5 & $\mathrm{~B}$ & & $8.00 \mathrm{E}-04$ & ORNL-5786 & $8.00 \mathrm{E}-04$ & $8.00 \mathrm{E}-04$ & NA \\
\hline 56 & $\mathrm{Ba}$ & & 2.00E-04 & PNNL-13421 & $1.50 \mathrm{E}-04$ & 3.00E-02 & NA \\
\hline 4 & $\mathrm{Be}$ & $1.0 \mathrm{E}-03$ & $1.00 \mathrm{E}-03$ & PNNL-13421 & $1.00 \mathrm{E}-03$ & $5.00 \mathrm{E}-03$ & 1.0 \\
\hline 83 & $\mathrm{Bi}$ & $2.0 \mathrm{E}-03$ & $4.00 \mathrm{E}-04$ & PNNL-13421 & $4.00 \mathrm{E}-04$ & $2.00 \mathrm{E}-03$ & 0.2 \\
\hline 97 & $\mathrm{Bk}$ & $2.0 \mathrm{E}-05$ & $2.50 \mathrm{E}-05$ & NCRP 123 & $2.00 \mathrm{E}-05$ & 4.00E-05 & 1.3 \\
\hline 35 & $\mathrm{Br}$ & & $2.50 \mathrm{E}-02$ & PNNL-13421 & $2.00 \mathrm{E}-02$ & $5.00 \mathrm{E}-02$ & NA \\
\hline 6 & $\mathrm{C}$ & 3.1E-02 & $3.10 \mathrm{E}-02$ & NRC 1997 & $3.10 \mathrm{E}-02$ & 4.89E-02 & 1.0 \\
\hline 20 & $\mathrm{Ca}$ & $1.6 \mathrm{E}-03$ & $2.00 \mathrm{E}-03$ & PNNL-13421 & $7.00 \mathrm{E}-04$ & $2.00 \mathrm{E}-03$ & 1.3 \\
\hline 48 & $\mathrm{Cd}$ & 5.3E-04 & 4.00E-04 & PNNL-13421 & $4.00 \mathrm{E}-04$ & $1.00 \mathrm{E}-03$ & 0.8 \\
\hline 58 & $\mathrm{Ce}$ & & $2.00 \mathrm{E}-05$ & PNNL-13421 & $2.00 \mathrm{E}-05$ & $1.20 \mathrm{E}-03$ & NA \\
\hline 98 & $\mathrm{Cf}$ & $6.0 \mathrm{E}-05$ & 4.00E-05 & PNNL-13421 & $4.00 \mathrm{E}-05$ & $5.00 \mathrm{E}-03$ & 0.7 \\
\hline 17 & $\mathrm{Cl}$ & $6.0 \mathrm{E}-02$ & $2.00 \mathrm{E}-02$ & PNNL-13421 & $2.00 \mathrm{E}-02$ & $8.00 \mathrm{E}-02$ & 0.3 \\
\hline 96 & $\mathrm{Cm}$ & $2.0 \mathrm{E}-04$ & 4.00E-05 & PNNL-13421 & $3.50 \mathrm{E}-06$ & $2.00 \mathrm{E}-04$ & 0.2 \\
\hline 27 & Co & 1.3E-02 & $1.00 \mathrm{E}-02$ & PNNL-13421 & $1.00 \mathrm{E}-02$ & $3.00 \mathrm{E}-02$ & 0.8 \\
\hline 24 & $\mathrm{Cr}$ & & $9.00 \mathrm{E}-03$ & PNNL-13421 & $2.40 \mathrm{E}-03$ & $3.00 \mathrm{E}-02$ & NA \\
\hline 55 & Cs & $4.0 \mathrm{E}-03$ & $5.00 \mathrm{E}-02$ & PNNL-13421 & $4.00 \mathrm{E}-03$ & $5.00 \mathrm{E}-02$ & 12.5 \\
\hline 29 & $\mathrm{Cu}$ & & $9.00 \mathrm{E}-03$ & PNNL-13421 & 8.00E-03 & $1.00 \mathrm{E}-02$ & NA \\
\hline 66 & Dy & & $2.00 \mathrm{E}-05$ & PNNL-13421 & $2.00 \mathrm{E}-05$ & $5.50 \mathrm{E}-03$ & NA \\
\hline 68 & $\mathrm{Er}$ & & $2.00 \mathrm{E}-05$ & PNNL-13421 & $2.00 \mathrm{E}-05$ & $4.00 \mathrm{E}-03$ & NA \\
\hline 99 & Es & $2.0 \mathrm{E}-05$ & $2.50 \mathrm{E}-05$ & NCRP 123 & $2.00 \mathrm{E}-05$ & $2.50 \mathrm{E}-05$ & 1.3 \\
\hline 63 & $\mathrm{Eu}$ & & $2.00 \mathrm{E}-05$ & PNNL-13421 & $2.00 \mathrm{E}-05$ & 5.00E-03 & NA \\
\hline 9 & $\mathrm{~F}$ & & $1.50 \mathrm{E}-01$ & PNNL-13421 & $2.00 \mathrm{E}-02$ & $1.50 \mathrm{E}-01$ & NA \\
\hline 26 & $\mathrm{Fe}$ & 4.0E-02 & $2.00 \mathrm{E}-02$ & PNNL-13421 & $2.00 \mathrm{E}-02$ & $4.00 \mathrm{E}-02$ & 0.5 \\
\hline 100 & Fm & & $2.00 \mathrm{E}-04$ & NCRP 123 & $2.00 \mathrm{E}-04$ & $2.00 \mathrm{E}-04$ & NA \\
\hline 87 & $\mathrm{Fr}$ & $3.0 \mathrm{E}-02$ & $2.50 \mathrm{E}-03$ & ORNL-5786 & $2.50 \mathrm{E}-03$ & 3.00E-02 & 0.08 \\
\hline 31 & $\mathrm{Ga}$ & $3.0 \mathrm{E}-04$ & $5.00 \mathrm{E}-04$ & PNNL-13421 & $3.00 \mathrm{E}-04$ & $5.00 \mathrm{E}-04$ & 1.7 \\
\hline 64 & Gd & 2.0E-03 & $2.00 \mathrm{E}-05$ & PNNL-13421 & $2.00 \mathrm{E}-05$ & 3.50E-03 & 0.01 \\
\hline 32 & $\mathrm{Ge}$ & 7.0E-01 & $7.00 \mathrm{E}-01$ & ORNL-5786 & $2.00 \mathrm{E}-01$ & $7.00 \mathrm{E}-01$ & 1.0 \\
\hline 1 & $\mathrm{H}$ & & & Not Used in Model & 0 & $1.20 \mathrm{E}-02$ & NA \\
\hline 105 & $\mathrm{Ha}$ & & $5.00 \mathrm{E}-06$ & NCRP 123 & $5.00 \mathrm{E}-06$ & $5.00 \mathrm{E}-06$ & NA \\
\hline
\end{tabular}

*Values greater than two orders of magnitude from the currently used values (update/current ratio $>100$ or $<0.01$ ) are geometrically averaged to create the "updated value". 
Table B- 3. Comprehensive Updated Feed-to-Meat Bioaccumulation Factors (continued)

\begin{tabular}{|c|c|c|c|c|c|c|c|}
\hline \multirow[b]{2}{*}{$\mathbf{Z}$} & \multirow[b]{2}{*}{ Element } & \multirow{2}{*}{$\begin{array}{c}\text { Current SRS } \\
\text { Value } \\
\end{array}$} & \multicolumn{4}{|c|}{ Updated Feed-to-Meat Transfer Factors } & \multirow{2}{*}{$\begin{array}{c}\text { Update/Current } \\
\text { Use Ratio* }\end{array}$} \\
\hline & & & Updated Value & Reference & Min & Max & \\
\hline 72 & Hf & $1.0 \mathrm{E}-06$ & 3.16E-05* & PNNL-13421 & $1.00 \mathrm{E}-06$ & $1.00 \mathrm{E}-03$ & 1,000 \\
\hline 80 & $\mathrm{Hg}$ & $1.0 \mathrm{E}-01$ & $2.50 \mathrm{E}-01$ & PNNL-13421 & $1.00 \mathrm{E}-02$ & $2.50 \mathrm{E}-01$ & 2.5 \\
\hline 67 & Ho & 4.5E-03 & $3.00 \mathrm{E}-04 \dagger$ & PNNL-13421 & $2.00 \mathrm{E}-05$ & 4.50E-03 & 0.004 \\
\hline 53 & $\mathrm{I}$ & 2.9E-03 & 4.00E-02 & PNNL-13421 & 2.90E-03 & 4.00E-02 & 13.8 \\
\hline 49 & In & 4.0E-03 & 8.00E-03 & PNNL-13421 & 4.00E-03 & 8.00E-03 & 2.0 \\
\hline 77 & Ir & 2.0E-03 & $1.50 \mathrm{E}-03$ & PNNL-13421 & $1.50 \mathrm{E}-03$ & $2.00 \mathrm{E}-03$ & 0.8 \\
\hline 19 & $\mathrm{~K}$ & $2.0 \mathrm{E}-02$ & $2.00 \mathrm{E}-02$ & PNNL-13421 & $2.00 \mathrm{E}-02$ & $2.00 \mathrm{E}-02$ & 1.0 \\
\hline 57 & $\mathrm{La}$ & $2.0 \mathrm{E}-04$ & $2.00 \mathrm{E}-03$ & PNNL-13421 & $2.00 \mathrm{E}-04$ & $2.00 \mathrm{E}-03$ & 10.0 \\
\hline 3 & $\mathrm{Li}$ & & $1.00 \mathrm{E}-02$ & ORNL-5786 & $1.00 \mathrm{E}-02$ & $2.00 \mathrm{E}-02$ & NA \\
\hline 103 & $\mathrm{Lr}$ & & $2.00 \mathrm{E}-04$ & NCRP 123 & $2.00 \mathrm{E}-04$ & $2.00 \mathrm{E}-04$ & NA \\
\hline 71 & $\mathrm{Lu}$ & 4.5E-03 & 4.50E-03 & ORNL-5786 & $2.00 \mathrm{E}-03$ & 4.50E-03 & 1.0 \\
\hline 12 & $\mathrm{Mg}$ & & $2.00 \mathrm{E}-02$ & PNNL-13421 & $3.00 \mathrm{E}-03$ & $2.00 \mathrm{E}-02$ & NA \\
\hline 25 & Mn & 8.0E-04 & $5.00 \mathrm{E}-04$ & PNNL-13421 & $4.00 \mathrm{E}-04$ & $1.00 \mathrm{E}-03$ & 0.6 \\
\hline 42 & Mo & 8.0E-03 & $1.00 \mathrm{E}-03$ & PNNL-13421 & $1.00 \mathrm{E}-03$ & 8.00E-03 & 0.1 \\
\hline 7 & $\mathrm{~N}$ & & $7.50 \mathrm{E}-02$ & PNNL-13421 & $1.00 \mathrm{E}-02$ & $7.50 \mathrm{E}-02$ & NA \\
\hline 11 & $\mathrm{Na}$ & & 8.00E-02 & PNNL-13421 & $3.00 \mathrm{E}-02$ & 8.00E-02 & NA \\
\hline 41 & $\mathrm{Nb}$ & 2.8E-01 & $2.90 \mathrm{E}-04 \ddagger$ & PNNL-13421 & $3.00 \mathrm{E}-07$ & $2.80 \mathrm{E}-01$ & 0.000001 \\
\hline 60 & $\mathrm{Nd}$ & & 2.00E-05 & PNNL-13421 & $2.00 \mathrm{E}-05$ & 3.30E-03 & NA \\
\hline 28 & $\mathrm{Ni}$ & 5.3E-03 & 5.00E-03 & PNNL-13421 & $5.00 \mathrm{E}-03$ & $5.30 \mathrm{E}-02$ & 0.9 \\
\hline 102 & No & & $2.00 \mathrm{E}-04$ & NCRP 123 & $2.00 \mathrm{E}-04$ & $2.00 \mathrm{E}-04$ & NA \\
\hline 93 & $\mathrm{~Np}$ & 2.0E-04 & $1.00 \mathrm{E}-03$ & PNNL-13421 & 5.50E-05 & $1.00 \mathrm{E}-03$ & 5.0 \\
\hline 76 & Os & & 4.00E-01 & PNNL-13421 & $2.00 \mathrm{E}-03$ & $4.00 \mathrm{E}-01$ & NA \\
\hline 15 & $\mathrm{P}$ & 4.6E-02 & 5.00E-02 & PNNL-13421 & 4.60E-02 & $2.00 \mathrm{E}-01$ & 1.1 \\
\hline 91 & $\mathrm{~Pa}$ & $5.0 \mathrm{E}-03$ & 4.47E-04§ & PNNL-13421 & $5.00 \mathrm{E}-06$ & $5.00 \mathrm{E}-03$ & 0.008 \\
\hline 82 & $\mathrm{~Pb}$ & 8.0E-04 & 4.00E-04 & PNNL-13421 & $3.00 \mathrm{E}-04$ & 8.00E-04 & 0.5 \\
\hline 46 & $\mathrm{Pd}$ & $1.0 \mathrm{E}-03$ & 4.00E-03 & PNNL-13421 & $2.00 \mathrm{E}-04$ & 4.00E-03 & 4.0 \\
\hline 61 & $\mathrm{Pm}$ & & $2.00 \mathrm{E}-05$ & PNNL-13421 & $2.00 \mathrm{E}-05$ & $5.00 \mathrm{E}-03$ & NA \\
\hline 84 & Po & $5.0 \mathrm{E}-03$ & 5.00E-03 & PNNL-13421 & 9.50E-05 & $5.00 \mathrm{E}-03$ & 1.0 \\
\hline 59 & $\operatorname{Pr}$ & & 2.00E-05 & PNNL-13421 & 2.00E-05 & 4.70E-03 & NA \\
\hline 78 & $\mathrm{Pt}$ & $4.0 \mathrm{E}-03$ & 4.00E-03 & ORNL-5786 & $2.00 \mathrm{E}-04$ & $4.00 \mathrm{E}-03$ & 1.0 \\
\hline 94 & $\mathrm{Pu}$ & $1.4 \mathrm{E}-05$ & $1.00 \mathrm{E}-05$ & PNNL-13421 & $5.00 \mathrm{E}-07$ & $1.00 \mathrm{E}-04$ & 0.7 \\
\hline 88 & $\mathrm{Ra}$ & $1.0 \mathrm{E}-03$ & $9.00 \mathrm{E}-04$ & PNNL-13421 & $2.50 \mathrm{E}-04$ & $1.00 \mathrm{E}-03$ & 0.9 \\
\hline 37 & $\mathrm{Rb}$ & $3.1 \mathrm{E}-02$ & $1.00 \mathrm{E}-02$ & PNNL-13421 & $1.00 \mathrm{E}-02$ & $3.10 \mathrm{E}-02$ & 0.3 \\
\hline 75 & $\mathrm{Re}$ & $1.0 \mathrm{E}-04$ & 8.00E-03 & PNNL-13421 & $1.00 \mathrm{E}-04$ & $1.00 \mathrm{E}-02$ & 80.0 \\
\hline 45 & $\mathrm{Rh}$ & & $2.00 \mathrm{E}-03$ & PNNL-13421 & $1.00 \mathrm{E}-03$ & $2.00 \mathrm{E}-03$ & NA \\
\hline 86 & $\mathrm{Rn}$ & & 0 & NCRP 123 & 0 & 0 & NA \\
\hline 44 & $\mathrm{Ru}$ & 4.0E-01 & $5.00 \mathrm{E}-02$ & PNNL-13421 & $2.00 \mathrm{E}-03$ & $4.00 \mathrm{E}-01$ & 0.1 \\
\hline
\end{tabular}

*Geometric mean of PNNL-13421 site-specific value (1.00E-03) and currently used value. †Geometric mean of PNNL-13421 site-specific value (2.00E-05) and currently used value. \$Geometric mean of PNNL-13421 site-specific value (3.00E-07) and currently used value. §Geometric mean of PNNL-13421 site-specific value (4.00E-05) and currently used value. 
Table B- 3. Comprehensive Updated Feed-to-Meat Bioaccumulation Factors (continued)

\begin{tabular}{|c|c|c|c|c|c|c|c|}
\hline \multirow[b]{2}{*}{$\mathbf{Z}$} & \multirow[b]{2}{*}{ Element } & \multirow{2}{*}{$\begin{array}{c}\text { Current SRS } \\
\text { Value } \\
\end{array}$} & \multicolumn{4}{|c|}{ Updated Feed-to-Meat Transfer Factors } & \multirow{2}{*}{$\begin{array}{c}\text { Update/Current } \\
\text { Use Ratio* }\end{array}$} \\
\hline & & & Updated Value & Reference & Min & Max & \\
\hline 16 & $\mathrm{~S}$ & & 2.00E-01 & PNNL-13421 & $1.00 \mathrm{E}-01$ & 2.00E-01 & NA \\
\hline 51 & $\mathrm{Sb}$ & 4.0E-03 & $1.00 \mathrm{E}-03$ & PNNL-13421 & 4.00E-05 & 4.00E-03 & 0.3 \\
\hline 21 & Sc & 2.0E-03 & $1.50 \mathrm{E}-02$ & PNNL-13421 & 2.00E-03 & $1.50 \mathrm{E}-02$ & 7.5 \\
\hline 34 & Se & 1.5E-02 & $1.50 \mathrm{E}-02$ & PNNL-13421 & 1.50E-02 & $1.00 \mathrm{E}-01$ & 1.0 \\
\hline 14 & $\mathrm{Si}$ & 4.0E-05 & 4.00E-05 & PNNL-13421 & 4.00E-05 & 3.00E-04 & 1.0 \\
\hline 62 & Sm & 5.0E-03 & 3.16E-04* & PNNL-13421 & $2.00 \mathrm{E}-05$ & $5.00 \mathrm{E}-03$ & 0.004 \\
\hline 50 & Sn & 8.0E-02 & 8.00E-02 & PNNL-13421 & $1.00 \mathrm{E}-02$ & 8.00E-02 & 1.0 \\
\hline 38 & $\mathrm{Sr}$ & $6.0 \mathrm{E}-04$ & 8.00E-03 & PNNL-13421 & 3.00E-04 & $1.00 \mathrm{E}-02$ & 13.3 \\
\hline 73 & $\mathrm{Ta}$ & $6.0 \mathrm{E}-04$ & $1.34 \mathrm{E}-05 \dagger$ & PNNL-13421 & $3.00 \mathrm{E}-07$ & $6.00 \mathrm{E}-04$ & 0.0005 \\
\hline 65 & $\mathrm{~Tb}$ & & $2.00 \mathrm{E}-05$ & PNNL-13421 & $2.00 \mathrm{E}-05$ & 4.50E-03 & NA \\
\hline 43 & Tc & 4.0E-01 & $6.32 \mathrm{E}-03 \ddagger$ & PNNL-13421 & $1.00 \mathrm{E}-04$ & $4.00 \mathrm{E}-01$ & 0.0003 \\
\hline 52 & $\mathrm{Te}$ & 7.7E-02 & 7.00E-03 & PNNL-13421 & 7.00E-03 & 7.70E-02 & 0.09 \\
\hline 90 & Th & $2.0 \mathrm{E}-04$ & 4.00E-05 & PNNL-13421 & $6.00 \mathrm{E}-06$ & 2.00E-04 & 0.2 \\
\hline 22 & $\mathrm{Ti}$ & $1.0 \mathrm{E}-06$ & $1.73 \mathrm{E}-04 \S$ & ORNL-5786 & $1.00 \mathrm{E}-06$ & $3.00 \mathrm{E}-02$ & 30,000 \\
\hline 81 & $\mathrm{Tl}$ & 2.0E-02 & $4.00 \mathrm{E}-02$ & PNNL-13421 & 2.00E-03 & 4.00E-02 & 2.0 \\
\hline 69 & $\mathrm{Tm}$ & & 4.50E-03 & ORNL-5786 & 2.00E-03 & $4.50 \mathrm{E}-03$ & NA \\
\hline 92 & $\mathrm{U}$ & 3.4E-04 & $3.00 \mathrm{E}-04$ & PNNL-13421 & 2.00E-04 & 8.00E-04 & 0.9 \\
\hline 23 & $\mathrm{~V}$ & 2.5E-03 & $2.50 \mathrm{E}-03$ & ORNL-5786 & 2.50E-03 & $1.00 \mathrm{E}-02$ & 1.0 \\
\hline 74 & $\mathrm{~W}$ & & 4.00E-02 & PNNL-13421 & $1.30 \mathrm{E}-03$ & 4.50E-02 & NA \\
\hline 39 & $\mathrm{Y}$ & 4.6E-03 & $1.00 \mathrm{E}-03$ & PNNL-13421 & 3.00E-04 & 8.00E-03 & 0.2 \\
\hline 70 & $\mathrm{Yb}$ & & 4.00E-03 & ORNL-5786 & 2.00E-03 & $4.00 \mathrm{E}-03$ & NA \\
\hline 30 & $\mathrm{Zn}$ & & $1.00 \mathrm{E}-01$ & PNNL-13421 & 3.00E-02 & $1.00 \mathrm{E}-01$ & NA \\
\hline 40 & $\mathrm{Zr}$ & 3.4E-02 & $1.84 \mathrm{E}-04 * *$ & PNNL-13421 & $1.00 \mathrm{E}-06$ & $3.40 \mathrm{E}-02$ & 0.00003 \\
\hline
\end{tabular}

\footnotetext{
* Geometric mean of PNNL-13421 site-specific value (2.00E-05) and currently used value. †Geometric mean of PNNL-13421 site-specific value (3.00E-07) and currently used value. ¥Geometric mean of PNNL-13421 site-specific value (1.00E-04) and currently used value. §Geometric mean of PNNL-13421 site-specific value (3.00E-02) and currently used value. **Geometric mean of PNNL-13421 site-specific value (1.00E-06) and currently used value.
} 
Table B- 4. Comprehensive Updated Water-to-Fish Bioaccumulation Factors (L/kg)

\begin{tabular}{|c|c|c|c|c|c|c|c|}
\hline \multirow[b]{2}{*}{$\mathbf{Z}$} & \multirow[b]{2}{*}{ Element } & \multirow{2}{*}{$\begin{array}{c}\text { Current } \\
\text { SRS Value }\end{array}$} & \multicolumn{4}{|c|}{ Updated Water-to-Fish Bioaccumulation Factors } & \multirow{2}{*}{$\begin{array}{c}\text { Update/Current } \\
\text { Use Ratio }\end{array}$} \\
\hline & & & Updated Value & Reference & Min & Max & \\
\hline 89 & Ac & $2.5 \mathrm{E}+01$ & $2.50 \mathrm{E}+01$ & PNNL-13421 & $1.50 \mathrm{E}+01$ & $2.50 \mathrm{E}+01$ & 1.0 \\
\hline 47 & $\mathrm{Ag}$ & $2.3 \mathrm{E}+00$ & $5.00 \mathrm{E}+00$ & PNNL-13421 & $2.30 \mathrm{E}+00$ & $5.00 \mathrm{E}+00$ & 2.2 \\
\hline 13 & $\mathrm{Al}$ & $1.0 \mathrm{E}+01$ & $5.00 \mathrm{E}+02$ & NCRP 123 & $1.00 \mathrm{E}+01$ & $5.00 \mathrm{E}+02$ & 50.0 \\
\hline 95 & Am & $2.5 \mathrm{E}+01$ & $3.00 \mathrm{E}+01$ & PNNL-13421 & $2.10 \mathrm{E}+01$ & $2.40 \mathrm{E}+03$ & 1.2 \\
\hline 33 & As & & $1.70 \mathrm{E}+03$ & PNNL-13421 & $1.00 \mathrm{E}+02$ & $1.70 \mathrm{E}+03$ & NA \\
\hline 85 & At & $1.5 \mathrm{E}+01$ & $1.50 \mathrm{E}+01$ & NCRP 123 & $1.50 \mathrm{E}+01$ & $1.50 \mathrm{E}+01$ & 1.0 \\
\hline 79 & $\mathrm{Au}$ & $3.5 \mathrm{E}+01$ & $3.30 \mathrm{E}+01$ & PNNL-13421 & $3.30 \mathrm{E}+01$ & $3.50 \mathrm{E}+01$ & 0.9 \\
\hline 56 & $\mathrm{Ba}$ & & $4.00 \mathrm{E}+00$ & PNNL-13421 & $4.00 \mathrm{E}+00$ & $2.00 \mathrm{E}+02$ & NA \\
\hline 4 & $\mathrm{Be}$ & $2.0 \mathrm{E}+00$ & $1.00 \mathrm{E}+02$ & PNNL-13421 & $2.00 \mathrm{E}+00$ & $1.00 \mathrm{E}+02$ & 50.0 \\
\hline 83 & $\mathrm{Bi}$ & $1.5 \mathrm{E}+01$ & $1.50 \mathrm{E}+01$ & PNNL-13421 & $1.00 \mathrm{E}+01$ & $1.50 \mathrm{E}+01$ & 1.0 \\
\hline 97 & $\mathrm{Bk}$ & $2.5 \mathrm{E}+01$ & $2.50 \mathrm{E}+01$ & NCRP 123 & $2.50 \mathrm{E}+01$ & $2.50 \mathrm{E}+01$ & 1.0 \\
\hline 35 & $\mathrm{Br}$ & & $4.00 \mathrm{E}+02$ & PNNL-13421 & $4.00 \mathrm{E}+02$ & $4.20 \mathrm{E}+02$ & NA \\
\hline 6 & $\mathrm{C}$ & $4.6 \mathrm{E}+03$ & $5.00 \mathrm{E}+04$ & PNNL-13421 & $4.60 \mathrm{E}+03$ & $5.00 \mathrm{E}+04$ & 10.9 \\
\hline 20 & $\mathrm{Ca}$ & $4.0 \mathrm{E}+01$ & $4.00 \mathrm{E}+01$ & PNNL-13421 & $4.00 \mathrm{E}+01$ & $1.00 \mathrm{E}+03$ & 1.0 \\
\hline 48 & $\mathrm{Cd}$ & $2.0 \mathrm{E}+02$ & $2.00 \mathrm{E}+02$ & PNNL-13421 & $2.00 \mathrm{E}+02$ & $2.00 \mathrm{E}+02$ & 1.0 \\
\hline 58 & $\mathrm{Ce}$ & & $3.00 \mathrm{E}+01$ & PNNL-13421 & $1.00 \mathrm{E}+00$ & $5.00 \mathrm{E}+02$ & NA \\
\hline 98 & Cf & $2.5 \mathrm{E}+01$ & $2.50 \mathrm{E}+01$ & PNNL-13421 & $2.50 \mathrm{E}+01$ & $2.50 \mathrm{E}+01$ & 1.0 \\
\hline 17 & $\mathrm{Cl}$ & $5.0 \mathrm{E}+01$ & $5.00 \mathrm{E}+01$ & PNNL-13421 & $5.00 \mathrm{E}+01$ & $1.00 \mathrm{E}+03$ & 1.0 \\
\hline 96 & $\mathrm{Cm}$ & $2.5 \mathrm{E}+01$ & $3.00 \mathrm{E}+01$ & PNNL-13421 & $2.10 \mathrm{E}+01$ & $2.50 \mathrm{E}+02$ & 1.2 \\
\hline 27 & Co & $5.0 \mathrm{E}+01$ & $3.00 \mathrm{E}+02$ & PNNL-13421 & $5.00 \mathrm{E}+01$ & $3.30 \mathrm{E}+02$ & 6.0 \\
\hline 24 & $\mathrm{Cr}$ & & $4.00 \mathrm{E}+00$ & PNNL-13421 & $4.00 \mathrm{E}+00$ & $2.00 \mathrm{E}+02$ & NA \\
\hline 55 & Cs & $3.0 \mathrm{E}+03$ & $3.00 \mathrm{E}+03$ & Jannik 2003 & $2.00 \mathrm{E}+03$ & $4.70 \mathrm{E}+03$ & 1.0 \\
\hline 29 & $\mathrm{Cu}$ & & $2.00 \mathrm{E}+02$ & PNNL-13421 & $5.00 \mathrm{E}+01$ & $2.00 \mathrm{E}+02$ & $\mathrm{NA}$ \\
\hline 66 & Dy & & $3.00 \mathrm{E}+01$ & PNNL-13421 & $3.00 \mathrm{E}+01$ & $3.00 \mathrm{E}+01$ & NA \\
\hline 68 & $\mathrm{Er}$ & & $3.00 \mathrm{E}+01$ & PNNL-13421 & $3.00 \mathrm{E}+01$ & $3.00 \mathrm{E}+01$ & NA \\
\hline 99 & Es & $1.0 \mathrm{E}+01$ & $2.50 \mathrm{E}+01$ & NCRP 123 & $1.00 \mathrm{E}+01$ & $2.50 \mathrm{E}+01$ & 2.5 \\
\hline 63 & $\mathrm{Eu}$ & & $3.00 \mathrm{E}+01$ & PNNL-13421 & $2.50 \mathrm{E}+01$ & $5.00 \mathrm{E}+01$ & NA \\
\hline 9 & $\mathrm{~F}$ & & $1.00 \mathrm{E}+01$ & PNNL-13421 & $1.00 \mathrm{E}+01$ & $1.00 \mathrm{E}+01$ & NA \\
\hline 26 & $\mathrm{Fe}$ & $1.0 \mathrm{E}+02$ & $2.00 \mathrm{E}+02$ & PNNL-13421 & $1.00 \mathrm{E}+02$ & $2.00 \mathrm{E}+03$ & 2.0 \\
\hline 87 & $\mathrm{Fr}$ & $3.0 \mathrm{E}+01$ & $3.00 \mathrm{E}+01$ & NCRP 123 & $3.00 \mathrm{E}+01$ & $3.00 \mathrm{E}+01$ & 1.0 \\
\hline 31 & $\mathrm{Ga}$ & $3.3 \mathrm{E}+02$ & $4.00 \mathrm{E}+02$ & PNNL-13421 & $3.33 \mathrm{E}+02$ & $4.00 \mathrm{E}+02$ & 1.2 \\
\hline 64 & $\mathrm{Gd}$ & $2.5 \mathrm{E}+01$ & $3.00 \mathrm{E}+01$ & PNNL-13421 & $2.50 \mathrm{E}+01$ & $3.00 \mathrm{E}+01$ & 1.2 \\
\hline 32 & $\mathrm{Ge}$ & $3.3 \mathrm{E}+03$ & $4.00 \mathrm{E}+03$ & NCRP 123 & $3.33 \mathrm{E}+03$ & $4.00 \mathrm{E}+03$ & 1.2 \\
\hline 2 & $\mathrm{He}$ & & $1.00 \mathrm{E}+00$ & PNNL-13421 & $1.00 \mathrm{E}+00$ & $1.00 \mathrm{E}+00$ & NA \\
\hline 1 & $\mathrm{H}$ & $9.0 \mathrm{E}-01$ & $1.00 \mathrm{E}+00$ & NCRP 123 & $9.00 \mathrm{E}-01$ & $1.00 \mathrm{E}+00$ & 1.1 \\
\hline 72 & $\mathrm{Hf}$ & $3.3 \mathrm{E}+00$ & $3.00 \mathrm{E}+02$ & PNNL-13421 & $3.33 E+00$ & $3.00 \mathrm{E}+02$ & 90.1 \\
\hline 80 & $\mathrm{Hg}$ & $1.0 \mathrm{E}+03$ & $1.00 \mathrm{E}+03$ & PNNL-13421 & $1.00 \mathrm{E}+03$ & $1.00 \mathrm{E}+03$ & 1.0 \\
\hline 67 & Ho & $2.5 \mathrm{E}+01$ & $3.00 \mathrm{E}+01$ & PNNL-13421 & $2.50 \mathrm{E}+01$ & $3.00 \mathrm{E}+01$ & 1.2 \\
\hline 53 & $\mathrm{I}$ & $1.5 \mathrm{E}+01$ & $4.00 \mathrm{E}+01$ & PNNL-13421 & $1.50 \mathrm{E}+01$ & $5.00 \mathrm{E}+02$ & 2.7 \\
\hline 49 & In & $1.0 \mathrm{E}+04$ & $1.00 \mathrm{E}+04$ & PNNL-13421 & $1.00 \mathrm{E}+04$ & $1.00 \mathrm{E}+05$ & 1.0 \\
\hline 77 & Ir & $1.0 \mathrm{E}+01$ & $1.00 \mathrm{E}+01$ & PNNL-13421 & $1.00 \mathrm{E}+01$ & $1.00 \mathrm{E}+01$ & 1.0 \\
\hline
\end{tabular}


Table B- 4.Comprehensive Updated Water-to-Fish Bioaccumulation Factors (L/kg) (continued)

\begin{tabular}{|c|c|c|c|c|c|c|c|}
\hline \multirow[b]{2}{*}{$\mathbf{Z}$} & \multirow[b]{2}{*}{ Element } & \multirow{2}{*}{$\begin{array}{c}\text { Current } \\
\text { SRS Value } \\
\end{array}$} & \multicolumn{4}{|c|}{ Updated Water-to-Fish Bioaccumulation Factors } & \multirow{2}{*}{$\begin{array}{c}\text { Update/Curren } \\
\text { Use Ratio } \\
\end{array}$} \\
\hline & & & Updated Value & Reference & Min & Max & \\
\hline 19 & K & $1.0 \mathrm{E}+03$ & $1.00 \mathrm{E}+03$ & PNNL-13421 & $1.00 \mathrm{E}+03$ & $1.00 \mathrm{E}+04$ & 1.0 \\
\hline 57 & $\mathrm{La}$ & $2.5 \mathrm{E}+01$ & $3.00 \mathrm{E}+01$ & PNNL-13421 & $2.50 \mathrm{E}+01$ & $3.00 \mathrm{E}+01$ & 1.2 \\
\hline 71 & $\mathrm{Lu}$ & $2.5 \mathrm{E}+01$ & $2.50 \mathrm{E}+01$ & NCRP 123 & $2.50 \mathrm{E}+01$ & $2.50 \mathrm{E}+01$ & 1.0 \\
\hline 12 & $\mathrm{Mg}$ & & $5.00 \mathrm{E}+01$ & PNNL-13421 & $5.00 \mathrm{E}+01$ & $5.00 \mathrm{E}+01$ & NA \\
\hline 25 & Mn & $1.0 \mathrm{E}+02$ & $4.00 \mathrm{E}+02$ & PNNL-13421 & $1.00 \mathrm{E}+02$ & $4.00 \mathrm{E}+02$ & 4.0 \\
\hline 42 & Mo & $1.0 \mathrm{E}+01$ & $1.00 \mathrm{E}+01$ & PNNL-13421 & $1.00 \mathrm{E}+01$ & $1.00 \mathrm{E}+01$ & 1.0 \\
\hline 7 & $\mathrm{~N}$ & & $2.00 \mathrm{E}+05$ & PNNL-13421 & $1.50 \mathrm{E}+05$ & $2.00 \mathrm{E}+05$ & NA \\
\hline 11 & $\mathrm{Na}$ & & $2.00 \mathrm{E}+01$ & PNNL-13421 & $8.00 \mathrm{E}+00$ & $1.00 \mathrm{E}+02$ & NA \\
\hline 41 & $\mathrm{Nb}$ & $3.0 \mathrm{E}+04$ & $3.00 \mathrm{E}+02$ & PNNL-13421 & $2.00 \mathrm{E}+02$ & $3.00 \mathrm{E}+04$ & 0.0 \\
\hline 60 & $\mathrm{Nd}$ & & $3.00 \mathrm{E}+01$ & PNNL-13421 & $2.50 \mathrm{E}+01$ & $1.00 \mathrm{E}+02$ & NA \\
\hline 28 & $\mathrm{Ni}$ & $1.0 \mathrm{E}+02$ & $1.00 \mathrm{E}+02$ & PNNL-13421 & $1.00 \mathrm{E}+02$ & $1.00 \mathrm{E}+02$ & 1.0 \\
\hline 93 & $\mathrm{~Np}$ & $1.0 \mathrm{E}+02$ & $2.10 \mathrm{E}+01$ & PNNL-13421 & $1.00 \mathrm{E}+01$ & $2.50 \mathrm{E}+02$ & 0.2 \\
\hline 8 & $\mathrm{O}$ & & $1.00 \mathrm{E}+00$ & PNNL-13421 & $1.00 \mathrm{E}+00$ & $1.00 \mathrm{E}+00$ & NA \\
\hline 76 & Os & $1.0 \mathrm{E}+05$ & $1.00 \mathrm{E}+03 *$ & PNNL-13421 & $1.00 \mathrm{E}+01$ & $1.00 \mathrm{E}+05$ & 0.0001 \\
\hline 15 & $\mathrm{P}$ & & $5.00 \mathrm{E}+04$ & PNNL-13421 & $1.50 \mathrm{E}+03$ & $1.00 \mathrm{E}+05$ & NA \\
\hline 91 & $\mathrm{~Pa}$ & $1.1 \mathrm{E}+01$ & $1.00 \mathrm{E}+01$ & PNNL-13421 & $1.00 \mathrm{E}+01$ & $1.13 \mathrm{E}+01$ & 0.9 \\
\hline 82 & $\mathrm{~Pb}$ & $3.0 \mathrm{E}+02$ & $3.00 \mathrm{E}+02$ & PNNL-13421 & $1.00 \mathrm{E}+02$ & $3.00 \mathrm{E}+02$ & 1.0 \\
\hline 46 & $\mathrm{Pd}$ & $1.0 \mathrm{E}+01$ & $1.00 \mathrm{E}+01$ & PNNL-13421 & $1.00 \mathrm{E}+01$ & $1.00 \mathrm{E}+01$ & 1.0 \\
\hline 61 & $\mathrm{Pm}$ & & $3.00 \mathrm{E}+01$ & PNNL-13421 & $2.50 \mathrm{E}+01$ & $3.00 \mathrm{E}+01$ & NA \\
\hline 84 & Po & $5.0 \mathrm{E}+02$ & $5.00 \mathrm{E}+01$ & PNNL-13421 & $5.00 \mathrm{E}+01$ & $5.00 \mathrm{E}+02$ & 0.1 \\
\hline 59 & $\operatorname{Pr}$ & & $3.00 \mathrm{E}+01$ & PNNL-13421 & $2.50 \mathrm{E}+01$ & $1.00 \mathrm{E}+02$ & NA \\
\hline 78 & $\mathrm{Pt}$ & $1.0 \mathrm{E}+02$ & $3.50 \mathrm{E}+01$ & NCRP 123 & $3.50 \mathrm{E}+01$ & $1.00 \mathrm{E}+02$ & 0.4 \\
\hline 94 & $\mathrm{Pu}$ & $3.5 \mathrm{E}+00$ & $3.00 \mathrm{E}+01$ & PNNL-13421 & $3.50 \mathrm{E}+00$ & $4.70 \mathrm{E}+03$ & 8.6 \\
\hline 88 & $\mathrm{Ra}$ & $5.0 \mathrm{E}+01$ & $5.00 \mathrm{E}+01$ & PNNL-13421 & $5.00 \mathrm{E}+01$ & $7.00 \mathrm{E}+01$ & 1.0 \\
\hline 37 & $\mathrm{Rb}$ & $2.0 \mathrm{E}+03$ & $2.00 \mathrm{E}+03$ & PNNL-13421 & $2.00 \mathrm{E}+03$ & $2.00 \mathrm{E}+03$ & 1.0 \\
\hline 75 & $\mathrm{Re}$ & $1.2 \mathrm{E}+02$ & $1.20 \mathrm{E}+02$ & PNNL-13421 & $1.19 \mathrm{E}+02$ & $1.20 \mathrm{E}+04$ & 1.0 \\
\hline 45 & $\mathrm{Rh}$ & & $1.00 \mathrm{E}+01$ & PNNL-13421 & $1.00 \mathrm{E}+01$ & $1.00 \mathrm{E}+01$ & NA \\
\hline 45 & $\mathrm{Rn}$ & $5.7 \mathrm{E}+01$ & 0 & NCRP 123 & 0 & $5.70 \mathrm{E}+01$ & NA \\
\hline 44 & $\mathrm{Ru}$ & $1.0 \mathrm{E}+01$ & $1.00 \mathrm{E}+02$ & PNNL-13421 & $1.00 \mathrm{E}+01$ & $1.00 \mathrm{E}+02$ & 10.0 \\
\hline 16 & $\mathrm{~S}$ & & $8.00 \mathrm{E}+02$ & PNNL-13421 & $7.50 \mathrm{E}+02$ & $1.00 \mathrm{E}+03$ & NA \\
\hline 51 & $\mathrm{Sb}$ & $1.0 \mathrm{E}+00$ & $1.00 \mathrm{E}+02$ & PNNL-13421 & $1.00 \mathrm{E}+00$ & $2.00 \mathrm{E}+02$ & 100.0 \\
\hline 21 & Sc & $1.0 \mathrm{E}+02$ & $1.00 \mathrm{E}+02$ & PNNL-13421 & $1.00 \mathrm{E}+02$ & $1.00 \mathrm{E}+02$ & 1.0 \\
\hline 34 & Se & $1.7 \mathrm{E}+02$ & $1.70 \mathrm{E}+02$ & PNNL-13421 & $1.70 \mathrm{E}+02$ & $2.00 \mathrm{E}+02$ & 1.0 \\
\hline 14 & $\mathrm{Si}$ & $2.5 \mathrm{E}+00$ & $2.00 \mathrm{E}+01$ & PNNL-13421 & $2.50 \mathrm{E}+00$ & $2.00 \mathrm{E}+01$ & 8.0 \\
\hline 62 & $\mathrm{Sm}$ & $2.5 \mathrm{E}+01$ & $3.00 \mathrm{E}+01$ & PNNL-13421 & $2.50 \mathrm{E}+01$ & $3.00 \mathrm{E}+01$ & 1.2 \\
\hline 50 & Sn & $3.0 \mathrm{E}+03$ & $3.00 \mathrm{E}+03$ & PNNL-13421 & $3.00 \mathrm{E}+03$ & $3.00 \mathrm{E}+03$ & 1.0 \\
\hline 38 & $\mathrm{Sr}$ & $3.0 \mathrm{E}+01$ & $6.00 \mathrm{E}+01$ & PNNL-13421 & $3.00 \mathrm{E}+01$ & $5.01 \mathrm{E}+02$ & 2.0 \\
\hline 73 & $\mathrm{Ta}$ & $3.0 \mathrm{E}+04$ & $3.00 \mathrm{E}+02$ & PNNL-13421 & $1.00 \mathrm{E}+02$ & $3.00 \mathrm{E}+04$ & 0.01 \\
\hline 65 & $\mathrm{~Tb}$ & & $3.00 \mathrm{E}+01$ & PNNL-13421 & $2.50 \mathrm{E}+01$ & $3.00 \mathrm{E}+01$ & NA \\
\hline 43 & Tc & $1.5 \mathrm{E}+01$ & $2.00 \mathrm{E}+01$ & PNNL-13421 & $1.50 \mathrm{E}+01$ & $2.00 \mathrm{E}+01$ & 1.3 \\
\hline
\end{tabular}

*Geometric mean of PNNL-13421 site-specific value (1.00E+01) and currently used value. 
Table B- 4.Comprehensive Updated Water-to-Fish Bioaccumulation Factors (L/kg) (continued)

\begin{tabular}{|c|c|c|c|c|c|c|c|}
\hline \multirow[b]{2}{*}{$\mathbf{Z}$} & \multirow[b]{2}{*}{ Element } & \multirow{2}{*}{$\begin{array}{c}\text { Current } \\
\text { SRS Value }\end{array}$} & \multicolumn{4}{|c|}{ Updated Water-to-Fish Bioaccumulation Factors } & \multirow{2}{*}{$\begin{array}{c}\text { Update/Current } \\
\text { Use Ratio }\end{array}$} \\
\hline & & & Updated Value & Reference & Min & Max & \\
\hline 52 & $\mathrm{Te}$ & $4.0 \mathrm{E}+02$ & $4.00 \mathrm{E}+02$ & PNNL-13421 & $4.00 \mathrm{E}+02$ & $4.00 \mathrm{E}+02$ & 1.0 \\
\hline 90 & Th & $3.0 \mathrm{E}+01$ & $1.00 \mathrm{E}+02$ & PNNL-13421 & $3.00 \mathrm{E}+01$ & $1.00 \mathrm{E}+02$ & 3.3 \\
\hline 22 & $\mathrm{Ti}$ & $1.0 \mathrm{E}+03$ & $1.00 \mathrm{E}+03$ & NCRP 123 & $1.00 \mathrm{E}+03$ & $1.00 \mathrm{E}+03$ & 1.0 \\
\hline 81 & $\mathrm{Tl}$ & $1.0 \mathrm{E}+04$ & $1.00 \mathrm{E}+04$ & PNNL-13421 & $1.00 \mathrm{E}+04$ & $1.00 \mathrm{E}+04$ & 1.0 \\
\hline 92 & $\mathrm{U}$ & $2.0 \mathrm{E}+00$ & $1.00 \mathrm{E}+01$ & PNNL-13421 & $2.00 \mathrm{E}+00$ & $5.00 \mathrm{E}+01$ & 5.0 \\
\hline 23 & V & $1.0 \mathrm{E}+01$ & $2.00 \mathrm{E}+02$ & NCRP 123 & $1.00 \mathrm{E}+01$ & $2.00 \mathrm{E}+02$ & 20.0 \\
\hline 74 & $\mathrm{~W}$ & & $1.00 \mathrm{E}+01$ & PNNL-13421 & $1.00 \mathrm{E}+01$ & $1.20 \mathrm{E}+03$ & NA \\
\hline 39 & $\mathrm{Y}$ & $2.5 \mathrm{E}+01$ & $3.00 \mathrm{E}+01$ & PNNL-13421 & $2.50 \mathrm{E}+01$ & $3.00 \mathrm{E}+01$ & 1.2 \\
\hline 30 & $\mathrm{Zn}$ & & $3.50 \mathrm{E}+02$ & PNNL-13421 & $3.50 \mathrm{E}+02$ & $2.50 \mathrm{E}+03$ & NA \\
\hline 40 & $\mathrm{Zr}$ & $3.3 \mathrm{E}+00$ & $3.00 \mathrm{E}+02$ & PNNL-13421 & $3.30 \mathrm{E}+00$ & $3.00 \mathrm{E}+02$ & 90.9 \\
\hline
\end{tabular}


Table B- 5. Soil-to-Vegetable Transfer Factors from Other Sources

\begin{tabular}{|c|c|c|c|c|c|c|c|c|c|c|}
\hline \multirow[b]{2}{*}{$\mathbf{Z}$} & \multirow[b]{2}{*}{ Element } & \multirow{2}{*}{$\begin{array}{c}\text { PNNL-13421 } \\
\text { (Staven et al. 2003) } \\
\text { Table } 2-4 * 0.195\end{array}$} & \multirow{2}{*}{$\begin{array}{c}\text { ORNL-5786 } \\
\text { (Baes et al. 1984) } \\
\text { Figure } 2.2^{*} \mathbf{0 . 1 9 5}\end{array}$} & \multirow{2}{*}{$\begin{array}{c}\text { NUREG CR-5512 } \\
\text { (Kennedy and Strenge } \\
\text { 1992) } \\
\text { Table 6.16*0.195 }\end{array}$} & \multirow{2}{*}{$\begin{array}{c}\text { NCRP } 123 \\
\text { (NCRP 1996) } \\
\text { Table } 5.2\end{array}$} & \multicolumn{2}{|c|}{ IAEA 364} & \multirow{2}{*}{$\begin{array}{c}\text { CDC } 2006 \\
\text { (Table 8- } \\
3 * 0.195 \text { ) }\end{array}$} & \multirow{2}{*}{$\begin{array}{c}\text { RESRAD } \\
\text { Version } 6 \\
\text { (Yu et al. 2001) } \\
\text { Table D.3 }\end{array}$} & \multirow{2}{*}{$\begin{array}{c}\text { Reg Guide 1.109 } \\
\text { (NRC 1977) } \\
\text { Table E-1 }\end{array}$} \\
\hline & & & & & & $\begin{array}{l}\text { Low End } \\
95 \% \text { Root }\end{array}$ & $\begin{array}{l}\text { High End } \\
95 \% \text { Root }\end{array}$ & & & \\
\hline 89 & Ac & 6.83E-05 & 6.83E-05 & 6.83E-05 & $1.00 \mathrm{E}-03$ & & & & $2.50 \mathrm{E}-03$ & \\
\hline 47 & $\mathrm{Ag}$ & 2.54E-04 & 1.95E-02 & $2.54 \mathrm{E}-04$ & $4.00 \mathrm{E}-03$ & & & & $1.50 \mathrm{E}-01$ & $1.50 \mathrm{E}-01$ \\
\hline 13 & $\mathrm{Al}$ & & $1.27 \mathrm{E}-04$ & & $4.00 \mathrm{E}-03$ & & & & $4.00 \mathrm{E}-03$ & \\
\hline 95 & Am & 6.83E-05 & 4.88E-05 & $8.00 \mathrm{E}-05$ & $1.00 \mathrm{E}-03$ & $1.10 \mathrm{E}-05$ & \begin{tabular}{|l|}
$1.70 \mathrm{E}-01$ \\
\end{tabular} & 1.64E-04 & $1.00 \mathrm{E}-03$ & \\
\hline 18 & $\mathrm{Ar}$ & & 0 & & 0 & & & & 0 & \\
\hline 33 & As & 1.17E-03 & & $1.17 \mathrm{E}-03$ & $8.00 \mathrm{E}-02$ & & & & $8.00 \mathrm{E}-02$ & \\
\hline 85 & At & & 2.93E-02 & & $2.00 \mathrm{E}-01$ & & & & & \\
\hline 79 & $\mathrm{Au}$ & 3.51E-03 & 1.95E-02 & 1.95E-02 & $1.00 \mathrm{E}-01$ & & & & $1.00 \mathrm{E}-01$ & \\
\hline 5 & B & & 3.90E-01 & & $1.00 \mathrm{E}-02$ & & & & & \\
\hline 56 & $\mathrm{Ba}$ & 2.93E-03 & 2.93E-03 & 2.93E-03 & $1.00 \mathrm{E}-02$ & & & & $5.00 \mathrm{E}-03$ & $5.00 \mathrm{E}-03$ \\
\hline 4 & $\mathrm{Be}$ & 2.93E-04 & 2.93E-04 & 2.93E-04 & $4.00 \mathrm{E}-03$ & & & & $4.00 \mathrm{E}-03$ & \\
\hline 83 & $\mathrm{Bi}$ & 9.75E-02 & 9.75E-04 & 9.75E-04 & $1.00 \mathrm{E}-01$ & & & & $1.00 \mathrm{E}-01$ & \\
\hline 97 & $\mathrm{Bk}$ & & & & $1.00 \mathrm{E}-03$ & & & & & \\
\hline 35 & $\mathrm{Br}$ & 2.93E-01 & & 2.93E-01 & $4.00 \mathrm{E}-01$ & & & & 7.60E-01 & \\
\hline 6 & $\mathrm{C}$ & 1.37E-01 & & 1.37E-01 & & & & & $5.50 \mathrm{E}+00$ & $5.50 \mathrm{E}+00$ \\
\hline 20 & $\mathrm{Ca}$ & 6.83E-02 & 6.83E-02 & 6.83E-02 & $5.00 \mathrm{E}-01$ & & & & $5.00 \mathrm{E}-01$ & \\
\hline 48 & $\mathrm{Cd}$ & 2.93E-02 & $2.93 \mathrm{E}-02$ & 2.93E-02 & $5.00 \mathrm{E}-01$ & & & & $3.00 \mathrm{E}-01$ & \\
\hline 58 & $\mathrm{Ce}$ & 3.90E-03 & 7.80E-04 & 7.80E-04 & $2.00 \mathrm{E}-03$ & & & 5.85E-03 & $2.00 \mathrm{E}-03$ & $2.50 \mathrm{E}-03$ \\
\hline 98 & Cf & 6.83E-05 & & 1.95E-03 & $1.00 \mathrm{E}-03$ & & & & $1.00 \mathrm{E}-03$ & \\
\hline 17 & $\mathrm{Cl}$ & $1.37 \mathrm{E}+01$ & $1.37 \mathrm{E}+01$ & $1.37 \mathrm{E}+01$ & $2.00 \mathrm{E}+01$ & & & & $2.00 \mathrm{E}+01$ & \\
\hline 96 & $\mathrm{Cm}$ & 8.39E-05 & 2.93E-06 & $4.68 \mathrm{E}-05$ & $1.00 \mathrm{E}-03$ & $1.10 \mathrm{E}-05$ & \begin{tabular}{|l|}
$2.40 \mathrm{E}-03$ \\
\end{tabular} & & $1.00 \mathrm{E}-03$ & \\
\hline 27 & Co & $1.31 \mathrm{E}-02$ & $1.37 \mathrm{E}-03$ & $7.80 \mathrm{E}-03$ & $8.00 \mathrm{E}-02$ & $1.20 \mathrm{E}-02$ & $1.20 \mathrm{E}+00$ & $2.15 E-02$ & $8.00 \mathrm{E}-02$ & $9.40 \mathrm{E}-03$ \\
\hline 24 & $\mathrm{Cr}$ & 8.78E-04 & & 8.78E-04 & $1.00 \mathrm{E}-02$ & & & & $2.50 \mathrm{E}-04$ & $2.50 \mathrm{E}-04$ \\
\hline 55 & Cs & $2.54 \mathrm{E}-02$ & 5.85E-03 & $9.56 \mathrm{E}-03$ & $2.00 \mathrm{E}-01$ & $1.10 \mathrm{E}-03$ & $1.10 \mathrm{E}-01$ & $1.76 \mathrm{E}-01$ & $4.00 \mathrm{E}-02$ & $1.00 \mathrm{E}-02$ \\
\hline 29 & $\mathrm{Cu}$ & 4.88E-02 & & $4.88 \mathrm{E}-02$ & $5.00 \mathrm{E}-02$ & & & & $1.30 \mathrm{E}-01$ & $1.20 \mathrm{E}-01$ \\
\hline 66 & Dy & 3.90E-03 & & $7.80 \mathrm{E}-04$ & $2.00 \mathrm{E}-03$ & & & & & \\
\hline 68 & Er & 3.90E-03 & & $7.80 \mathrm{E}-04$ & $2.00 \mathrm{E}-03$ & & & & & \\
\hline 99 & Es & & & & $1.00 \mathrm{E}-03$ & & & & & \\
\hline
\end{tabular}


Table B- 5. Soil-to-Vegetable Transfer Factors from Other Sources (continued)

\begin{tabular}{|c|c|c|c|c|c|c|c|c|c|c|}
\hline \multirow[b]{2}{*}{$\mathbf{Z}$} & \multirow[b]{2}{*}{ Element } & \multirow{2}{*}{$\begin{array}{c}\text { PNNL-13421 } \\
\text { (Staven et al. 2003) } \\
\text { Table } 2-4 * 0.195\end{array}$} & \multirow{2}{*}{$\begin{array}{c}\text { ORNL-5786 } \\
\text { (Baes et al. 1984) } \\
\text { Figure } 2.2 * 0.195\end{array}$} & \multirow{2}{*}{$\begin{array}{c}\text { NUREG CR-5512 } \\
\text { (Kennedy and Strenge } \\
\text { 1992) } \\
\text { Table 6.16*0.195 }\end{array}$} & \multirow{2}{*}{$\begin{array}{c}\text { NCRP } 123 \\
\text { (NCRP 1996) } \\
\text { Table } 5.2\end{array}$} & \multicolumn{2}{|c|}{ IAEA 364} & \multirow{2}{*}{$\begin{array}{c}\text { CDC } 2006 \\
\text { (Table 8- } \\
3 * 0.195 \text { ) }\end{array}$} & \multirow{2}{*}{$\begin{array}{c}\text { RESRAD } \\
\text { Version } 6 \\
\text { (Yu et al. 2001) } \\
\text { Table D.3 } \\
\end{array}$} & \multirow{2}{*}{$\begin{array}{l}\text { Reg Guide 1.109 } \\
\text { (NRC 1977) } \\
\text { Table E-1 }\end{array}$} \\
\hline & & & & & & $\begin{array}{l}\text { Low End } \\
95 \% \text { Root }\end{array}$ & $\begin{array}{l}\text { High End } \\
95 \% \text { Root } \\
\end{array}$ & & & \\
\hline 63 & $\mathrm{Eu}$ & 3.90E-03 & $7.80 \mathrm{E}-04$ & $7.80 \mathrm{E}-04$ & $2.00 \mathrm{E}-03$ & & & & $2.50 \mathrm{E}-03$ & \\
\hline 9 & $F$ & 1.17E-03 & & 1.17E-03 & $2.00 \mathrm{E}-02$ & & & & $2.00 \mathrm{E}-02$ & \\
\hline 26 & $\mathrm{Fe}$ & 9.75E-03 & 1.95E-04 & 1.95E-04 & 1.00E-03 & & & & $1.00 \mathrm{E}-03$ & $6.60 \mathrm{E}-04$ \\
\hline 100 & $\mathrm{Fm}$ & & & & $2.00 \mathrm{E}-03$ & & & & & \\
\hline 87 & $\mathrm{Fr}$ & & 5.85E-03 & & $3.00 \mathrm{E}-02$ & & & & & \\
\hline 31 & $\mathrm{Ga}$ & 7.80E-05 & 7.80E-05 & $7.80 \mathrm{E}-05$ & $3.00 \mathrm{E}-03$ & & & & & \\
\hline 64 & $\mathrm{Gd}$ & 3.90E-03 & $7.80 \mathrm{E}-04$ & $7.80 \mathrm{E}-04$ & $2.00 \mathrm{E}-03$ & & & & $2.50 \mathrm{E}-03$ & \\
\hline 32 & $\mathrm{Ge}$ & & $1.56 \mathrm{E}-02$ & & $4.00 \mathrm{E}-01$ & & & & $4.00 \mathrm{E}-01$ & \\
\hline 1 & $\mathrm{H}$ & & & & & & & & $4.80 \mathrm{E}+00$ & $4.80 \mathrm{E}+00$ \\
\hline 108 & На & & & & $2.00 \mathrm{E}-03$ & & & & & \\
\hline 2 & $\mathrm{He}$ & & & & 0 & & & & & \\
\hline 72 & $\mathrm{Hf}$ & 1.95E-04 & 1.66E-04 & $1.66 \mathrm{E}-04$ & $3.00 \mathrm{E}-03$ & & & & & \\
\hline 80 & $\mathrm{Hg}$ & 3.90E-02 & 3.90E-02 & $3.90 \mathrm{E}-02$ & $3.00 \mathrm{E}-01$ & & & & $3.80 \mathrm{E}-01$ & \\
\hline 67 & Ho & 3.90E-03 & $7.80 \mathrm{E}-04$ & $7.80 \mathrm{E}-04$ & $2.00 \mathrm{E}-03$ & & & & $2.60 \mathrm{E}-03$ & \\
\hline 53 & I & 7.80E-03 & 9.75E-03 & 9.75E-03 & $2.00 \mathrm{E}-02$ & $3.40 \mathrm{E}-04$ & $3.40 \mathrm{E}-02$ & $3.90 \mathrm{E}-03$ & $2.00 \mathrm{E}-02$ & $2.00 \mathrm{E}-02$ \\
\hline 49 & In & $7.80 \mathrm{E}-05$ & $7.80 \mathrm{E}-05$ & $7.80 \mathrm{E}-05$ & $3.00 \mathrm{E}-03$ & & & & $3.00 \mathrm{E}-03$ & \\
\hline 77 & Ir & 2.93E-03 & 2.93E-03 & 2.93E-03 & $3.00 \mathrm{E}-02$ & & & & $3.00 \mathrm{E}-02$ & \\
\hline 19 & $\mathrm{~K}$ & $1.07 \mathrm{E}-01$ & $1.07 \mathrm{E}-01$ & $1.07 \mathrm{E}-01$ & $3.00 \mathrm{E}-01$ & & & & $3.00 \mathrm{E}-01$ & \\
\hline 36 & $\mathrm{Kr}$ & & & & 0 & & & & 0 & \\
\hline 57 & $\mathrm{La}$ & 6.83E-05 & $7.80 \mathrm{E}-04$ & $1.25 \mathrm{E}-04$ & $2.00 \mathrm{E}-03$ & & & & $2.50 \mathrm{E}-03$ & $2.50 \mathrm{E}-03$ \\
\hline 3 & $\mathrm{Li}$ & & $7.80 \mathrm{E}-04$ & & $1.00 \mathrm{E}-03$ & & & & & \\
\hline 103 & $\mathrm{Lr}$ & & & & $2.00 \mathrm{E}-03$ & & & & & \\
\hline 71 & $\mathrm{Lu}$ & & 7.80E-04 & & $2.00 \mathrm{E}-03$ & & & & & \\
\hline 101 & $\mathrm{Md}$ & & & & $2.00 \mathrm{E}-03$ & & & & & \\
\hline 12 & $\mathrm{Mg}$ & $1.07 \mathrm{E}-01$ & & $1.07 \mathrm{E}-01$ & $3.00 \mathrm{E}-02$ & & & & & \\
\hline 25 & $\mathrm{Mn}$ & $3.90 \mathrm{E}-02$ & 9.75E-03 & 2.93E-02 & $3.00 \mathrm{E}-01$ & & & & $3.00 \mathrm{E}-01$ & $2.90 \mathrm{E}-02$ \\
\hline 42 & Mo & $1.56 \mathrm{E}-01$ & $1.17 \mathrm{E}-02$ & $1.17 \mathrm{E}-02$ & $1.00 \mathrm{E}-01$ & & & & $1.30 \mathrm{E}-01$ & $1.20 \mathrm{E}-01$ \\
\hline 7 & $\mathrm{~N}$ & 9.56E-03 & & $5.85 \mathrm{E}+00$ & $7.50 \mathrm{E}+00$ & & & & $7.50 \mathrm{E}+00$ & \\
\hline 11 & $\mathrm{Na}$ & 5.85E-02 & $1.07 \mathrm{E}-02$ & 1.07E-02 & $5.00 \mathrm{E}-02$ & & & & $5.00 \mathrm{E}-02$ & $5.20 \mathrm{E}-02$ \\
\hline 41 & $\mathrm{Nb}$ & 4.88E-03 & 9.75E-04 & 9.75E-04 & 1.00E-02 & & & 3.32E-03 & $1.00 \mathrm{E}-02$ & $9.40 \mathrm{E}-03$ \\
\hline 60 & $\mathrm{Nd}$ & $3.90 \mathrm{E}-03$ & & $7.80 \mathrm{E}-04$ & $2.00 \mathrm{E}-03$ & & & & $2.40 \mathrm{E}-03$ & $2.40 \mathrm{E}-03$ \\
\hline
\end{tabular}


Table B- 5. Soil-to-Vegetable Transfer Factors from Other Sources (continued)

\begin{tabular}{|c|c|c|c|c|c|c|c|c|c|c|}
\hline \multirow[b]{2}{*}{$\mathbf{Z}$} & \multirow[b]{2}{*}{ Element } & \multirow{2}{*}{$\begin{array}{c}\text { PNNL-13421 } \\
\text { (Staven et al. 2003) } \\
\text { Table } 2-4 * 0.195\end{array}$} & \multirow{2}{*}{$\begin{array}{c}\text { ORNL-5786 } \\
\text { (Baes et al. 1984) } \\
\text { Figure } 2.2 * 0.195\end{array}$} & \multirow{2}{*}{$\begin{array}{c}\text { NUREG CR-5512 } \\
\text { (Kennedy and Strenge } \\
\text { 1992) } \\
\text { Table 6.16*0.195 }\end{array}$} & \multirow{2}{*}{$\begin{array}{c}\text { NCRP } 123 \\
\text { (NCRP 1996) } \\
\text { Table } 5.2\end{array}$} & \multicolumn{2}{|c|}{ IAEA 364} & \multirow{2}{*}{$\begin{array}{c}\text { CDC 2006 } \\
\text { (Table 8- } \\
3 * 0.195) \\
\end{array}$} & \multirow{2}{*}{$\begin{array}{c}\text { RESRAD } \\
\text { Version } 6 \\
\text { (Yu et al. 2001) } \\
\text { Table D.3 } \\
\end{array}$} & \multirow{2}{*}{$\begin{array}{c}\text { Reg Guide } 1.109 \\
\text { (NRC 1977) } \\
\text { Table E-1 } \\
\end{array}$} \\
\hline & & & & & & $\begin{array}{l}\text { Low End } \\
95 \% \text { Root } \\
\end{array}$ & $\begin{array}{l}\text { High End } \\
95 \% \text { Root } \\
\end{array}$ & & & \\
\hline 10 & $\mathrm{Ne}$ & & & & 0 & & & & & \\
\hline 28 & $\mathrm{Ni}$ & $1.17 \mathrm{E}-02$ & $1.17 \mathrm{E}-02$ & $1.17 \mathrm{E}-02$ & $5.00 \mathrm{E}-02$ & $1.80 \mathrm{E}-02$ & $1.80 \mathrm{E}+00$ & & $5.00 \mathrm{E}-02$ & $1.90 \mathrm{E}-02$ \\
\hline 102 & No & & & & 2.00E-03 & & & & & \\
\hline 93 & $\mathrm{~Np}$ & $2.54 \mathrm{E}-03$ & 1.95E-03 & $1.83 \mathrm{E}-03$ & $2.00 \mathrm{E}-02$ & 7.10E-04 & $1.40 \mathrm{E}-01$ & & $2.00 \mathrm{E}-02$ & $2.50 \mathrm{E}-03$ \\
\hline 8 & $\mathrm{O}$ & & & & $6.00 \mathrm{E}-01$ & & & & & \\
\hline 76 & Os & 6.83E-04 & & 6.83E-04 & $3.00 \mathrm{E}-02$ & & & & & \\
\hline 15 & $\mathrm{P}$ & 6.83E-01 & 6.83E-01 & 6.83E-01 & $1.00 \mathrm{E}+00$ & & & 6.83E-01 & $1.00 \mathrm{E}+00$ & $1.10 \mathrm{E}+00$ \\
\hline 91 & $\mathrm{~Pa}$ & 6.83E-05 & 4.88E-05 & 4.88E-05 & $1.00 \mathrm{E}-02$ & & & & $1.00 \mathrm{E}-02$ & \\
\hline 82 & $\mathrm{~Pb}$ & 1.17E-03 & $1.76 \mathrm{E}-03$ & $6.24 \mathrm{E}-04$ & $4.00 \mathrm{E}-03$ & 1.30E-04 & $1.30 \mathrm{E}-02$ & & $1.00 \mathrm{E}-02$ & \\
\hline 46 & $\mathrm{Pd}$ & 7.80E-03 & 7.80E-03 & 7.80E-03 & $1.00 \mathrm{E}-01$ & & & & $1.00 \mathrm{E}-01$ & \\
\hline 61 & $\mathrm{Pm}$ & $3.90 \mathrm{E}-03$ & $7.80 \mathrm{E}-04$ & $7.80 \mathrm{E}-04$ & $2.00 \mathrm{E}-03$ & & & & $2.50 \mathrm{E}-03$ & \\
\hline 84 & Po & $1.37 \mathrm{E}-03$ & $7.80 \mathrm{E}-05$ & $1.76 \mathrm{E}-03$ & $1.00 \mathrm{E}-03$ & & & & $1.00 \mathrm{E}-03$ & \\
\hline 59 & $\operatorname{Pr}$ & 3.90E-03 & 7.80E-04 & 7.80E-04 & 2.00E-03 & & & & $2.50 \mathrm{E}-03$ & $2.50 \mathrm{E}-03$ \\
\hline 78 & $\mathrm{Pt}$ & & $4.88 \mathrm{E}-03$ & & $1.00 \mathrm{E}-01$ & & & & & \\
\hline 94 & $\mathrm{Pu}$ & 2.15E-04 & 8.78E-06 & 3.90E-05 & $1.00 \mathrm{E}-03$ & $3.80 \mathrm{E}-06$ & 5.60E-02 & $1.60 \mathrm{E}-04$ & $1.00 \mathrm{E}-03$ & \\
\hline 88 & $\mathrm{Ra}$ & $3.90 \mathrm{E}-04$ & 2.93E-03 & $6.24 \mathrm{E}-04$ & 4.00E-02 & $2.20 \mathrm{E}-03$ & $5.50 \mathrm{E}-02$ & & $4.00 \mathrm{E}-02$ & \\
\hline 37 & $\mathrm{Rb}$ & $1.76 \mathrm{E}-01$ & $1.37 \mathrm{E}-02$ & 1.37E-02 & $2.00 \mathrm{E}-01$ & & & & $1.30 \mathrm{E}-01$ & $1.30 \mathrm{E}-01$ \\
\hline 75 & $\operatorname{Re}$ & 6.83E-02 & & 6.83E-02 & $2.00 \mathrm{E}-01$ & & & & & \\
\hline 104 & $\mathrm{Rf}$ & & & & $3.00 \mathrm{E}-03$ & & & & & \\
\hline 45 & $\mathrm{Rh}$ & 7.80E-03 & 7.80E-03 & 7.80E-03 & $3.00 \mathrm{E}-02$ & & & & $1.30 \mathrm{E}-01$ & $1.30 \mathrm{E}+01$ \\
\hline 86 & $\mathrm{Rn}$ & & & 0 & 0 & & & & 0 & \\
\hline 44 & $\mathrm{Ru}$ & $7.80 \mathrm{E}-03$ & $3.90 \mathrm{E}-03$ & $3.90 \mathrm{E}-03$ & $3.00 \mathrm{E}-02$ & & & $7.80 \mathrm{E}-03$ & $3.00 \mathrm{E}-02$ & $5.00 \mathrm{E}-02$ \\
\hline 16 & $S$ & 2.93E-01 & 2.93E-01 & 2.93E-01 & 6.00E-01 & & & 2.93E-01 & $6.00 \mathrm{E}-01$ & \\
\hline 51 & $\mathrm{Sb}$ & $1.09 \mathrm{E}-04$ & 5.85E-03 & $1.09 \mathrm{E}-04$ & $1.00 \mathrm{E}-02$ & $1.10 \mathrm{E}-04$ & $2.80 \mathrm{E}-03$ & & $1.00 \mathrm{E}-02$ & \\
\hline 21 & Sc & 1.95E-04 & 1.95E-04 & 1.95E-04 & 2.00E-03 & & & & $2.00 \mathrm{E}-03$ & \\
\hline 34 & Se & 9.75E-03 & $4.88 \mathrm{E}-03$ & $4.88 \mathrm{E}-03$ & $1.00 \mathrm{E}-01$ & & & & $1.00 \mathrm{E}-01$ & \\
\hline 14 & $\mathrm{Si}$ & 1.37E-02 & 1.37E-02 & $1.37 \mathrm{E}-02$ & $2.00 \mathrm{E}-02$ & & & & & \\
\hline 62 & $\mathrm{Sm}$ & 3.90E-03 & $7.80 \mathrm{E}-04$ & 7.80E-04 & $2.00 \mathrm{E}-03$ & & & & $2.50 \mathrm{E}-03$ & \\
\hline 50 & Sn & 1.17E-03 & $1.17 \mathrm{E}-03$ & 1.17E-03 & $3.00 \mathrm{E}-01$ & & & & $2.50 \mathrm{E}-03$ & \\
\hline 38 & $\mathrm{Sr}$ & 9.75E-02 & 4.88E-02 & $1.58 \mathrm{E}-01$ & 3.00E-01 & $1.40 \mathrm{E}-01$ & $1.40 \mathrm{E}+01$ & 3.32E-01 & $3.00 \mathrm{E}-01$ & $1.70 \mathrm{E}-02$ \\
\hline 73 & $\mathrm{Ta}$ & $4.88 \mathrm{E}-03$ & $4.88 \mathrm{E}-04$ & $4.88 \mathrm{E}-04$ & $2.00 \mathrm{E}-03$ & & & & $2.00 \mathrm{E}-02$ & \\
\hline
\end{tabular}


Table B- 5. Soil-to-Vegetable Transfer Factors from Other Sources (continued)

\begin{tabular}{|c|c|c|c|c|c|c|c|c|c|c|}
\hline \multirow[b]{2}{*}{$\mathbf{Z}$} & \multirow[b]{2}{*}{ Element } & \multirow[b]{2}{*}{$\begin{array}{c}\text { PNNL-13421 } \\
\text { (Staven et al. 2003) } \\
\text { Table } 2-4 * 0.195\end{array}$} & \multirow[b]{2}{*}{$\begin{array}{c}\text { ORNL-5786 } \\
\text { (Baes et al. 1984) } \\
\text { Figure } 2.2 * 0.195\end{array}$} & \multirow{2}{*}{$\begin{array}{c}\text { NUREG CR-5512 } \\
\text { (Kennedy and Strenge } \\
\text { 1992) } \\
\text { Table 6.16*0.195 }\end{array}$} & \multirow[b]{2}{*}{$\begin{array}{c}\text { NCRP } 123 \\
\text { (NCRP 1996) } \\
\text { Table } 5.2\end{array}$} & \multicolumn{2}{|c|}{ IAEA 364} & \multirow[b]{2}{*}{$\begin{array}{l}\text { CDC } 2006 \\
\text { (Table 8- } \\
3^{* 0.195)}\end{array}$} & \multirow{2}{*}{$\begin{array}{c}\text { RESRAD } \\
\text { Version } 6 \\
\text { (Yu et al. 2001) } \\
\text { Table D.3 }\end{array}$} & \multirow[b]{2}{*}{$\begin{array}{l}\text { Reg Guide } 1.109 \\
\text { (NRC 1977) } \\
\text { Table E-1 }\end{array}$} \\
\hline & & & & & & $\begin{array}{c}\text { Low End } \\
95 \% \text { Root }\end{array}$ & $\begin{array}{l}\text { High End } \\
95 \% \text { Root }\end{array}$ & & & \\
\hline 65 & $\mathrm{~Tb}$ & $3.90 \mathrm{E}-03$ & & $7.80 \mathrm{E}-04$ & $2.00 \mathrm{E}-03$ & & & & $2.60 \mathrm{E}-03$ & \\
\hline 43 & Tc & $4.68 \mathrm{E}-02$ & 2.93E-01 & $2.15 \mathrm{E}-01$ & $5.00 \mathrm{E}+00$ & $2.40 \mathrm{E}+00$ & $2.40 \mathrm{E}+00$ & $5.46 \mathrm{E}+00$ & $5.00 \mathrm{E}+00$ & $2.50 \mathrm{E}-01$ \\
\hline 52 & $\mathrm{Te}$ & $7.80 \mathrm{E}-04$ & 7.80E-04 & $7.80 \mathrm{E}-04$ & $1.00 \mathrm{E}-01$ & & & & $6.00 \mathrm{E}-01$ & $1.30 \mathrm{E}+00$ \\
\hline 90 & Th & $6.44 \mathrm{E}-05$ & $1.66 \mathrm{E}-05$ & $2.34 \mathrm{E}-05$ & $1.00 \mathrm{E}-03$ & $3.00 \mathrm{E}-05$ & $7.50 \mathrm{E}-03$ & $1.35 \mathrm{E}-03$ & $1.00 \mathrm{E}-03$ & \\
\hline 22 & $\mathrm{Ti}$ & & 5.85E-04 & & 1.00E-03 & & & & & \\
\hline 81 & $\mathrm{Tl}$ & 7.80E-05 & 7.80E-05 & $7.80 \mathrm{E}-05$ & 2.00E-01 & & & & $2.00 \mathrm{E}-01$ & \\
\hline 69 & $\mathrm{Tm}$ & & 7.80E-04 & & $2.00 \mathrm{E}-03$ & & & & & \\
\hline 92 & $\mathrm{U}$ & $2.34 \mathrm{E}-03$ & $7.80 \mathrm{E}-04$ & $2.73 \mathrm{E}-03$ & $2.00 \mathrm{E}-03$ & $1.40 \mathrm{E}-03$ & $1.40 \mathrm{E}-01$ & $2.15 \mathrm{E}-03$ & $2.50 \mathrm{E}-03$ & \\
\hline 23 & $\mathrm{~V}$ & & 5.85E-04 & & 2.00E-03 & & & & & \\
\hline 74 & $\mathrm{~W}$ & 5.85E-01 & 1.95E-03 & 1.95E-03 & 8.00E-01 & & & & $1.80 \mathrm{E}-02$ & $1.80 \mathrm{E}-02$ \\
\hline 54 & $\mathrm{Xe}$ & & & 0 & 0 & & & & 0 & \\
\hline 39 & $\bar{Y}$ & 1.95E-03 & 1.17E-03 & 1.17E-03 & $2.00 \mathrm{E}-03$ & & & 1.95E-03 & $2.50 \mathrm{E}-03$ & $2.60 \mathrm{E}-03$ \\
\hline 70 & $\mathrm{Yb}$ & & $7.80 \mathrm{E}-04$ & & $2.00 \mathrm{E}-03$ & & & & & \\
\hline 30 & Zn & 6.83E-02 & & 1.15E-01 & $4.00 \mathrm{E}-01$ & & & $2.34 \mathrm{E}+00$ & $4.00 \mathrm{E}-01$ & $4.00 \mathrm{E}-01$ \\
\hline 40 & $\mathrm{Zr}$ & 1.95E-04 & $9.75 \mathrm{E}-05$ & 9.75E-05 & $1.00 \mathrm{E}-03$ & & & 1.95E-04 & $1.00 \mathrm{E}-03$ & 1.70E-04 \\
\hline
\end{tabular}


Table B- 6. Feed-to-Milk Transfer Factors (d/L) from Other Sources

\begin{tabular}{|c|c|c|c|c|c|c|c|c|c|}
\hline $\mathbf{Z}$ & Element & $\begin{array}{c}\text { PNNL-13421 } \\
\text { (Staven et al. } \\
\text { 2003) } \\
\text { Table } 2.8 \\
\end{array}$ & $\begin{array}{c}\text { NUREG CR-5512 } \\
\text { (Kennedy and Strenge } \\
\text { 1992) } \\
\text { Table 6.18 } \\
\end{array}$ & $\begin{array}{c}\text { ORNL-5786 (Baes } \\
\text { et al. 1984) } \\
\text { Figure } 2.24 \\
\end{array}$ & $\begin{array}{c}\text { NCRP } 123 \text { Vol I } \\
\text { (NCRP 1996) } \\
\text { Table } 5.2 \\
\end{array}$ & IAEA 364 & $\begin{array}{c}\text { CDC } 2006 \\
\text { (Table 8-6) }\end{array}$ & $\begin{array}{c}\text { Resrad Version } 6 \\
\text { (Yu et al. 2001) } \\
\text { Table D.4 } \\
\end{array}$ & $\begin{array}{c}\text { Reg Guide } 1.109 \\
\text { (NRC 1977) } \\
\text { Table E-1 } \\
\end{array}$ \\
\hline 89 & Ac & $2.00 \mathrm{E}-05$ & $2.0 \mathrm{E}-05$ & 2.1E-05 & $2.0 \mathrm{E}-06$ & & & 2.0E-05 & \\
\hline 47 & $\mathrm{Ag}$ & 5.00E-05 & $2.0 \mathrm{E}-02$ & $2.1 \mathrm{E}-02$ & 6.0E-03 & $5.0 \mathrm{E}-05$ & & 2.5E-02 & 5.0E-02 \\
\hline 13 & $\mathrm{Al}$ & & & 2.1E-04 & $2.0 \mathrm{E}-04$ & & & $2.0 \mathrm{E}-04$ & \\
\hline 95 & $\mathrm{Am}$ & $1.50 \mathrm{E}-06$ & $4.0 \mathrm{E}-07$ & $4.1 \mathrm{E}-07$ & $2.0 \mathrm{E}-06$ & $1.5 \mathrm{E}-06$ & $1.50 \mathrm{E}-06$ & $2.0 \mathrm{E}-06$ & \\
\hline 33 & As & $6.00 \mathrm{E}-05$ & $6.0 \mathrm{E}-05$ & $6.2 \mathrm{E}-05$ & $1.0 \mathrm{E}-04$ & & & $1.0 \mathrm{E}-04$ & \\
\hline 85 & At & & & $1.0 \mathrm{E}-02$ & $1.0 \mathrm{E}-02$ & & & & \\
\hline 79 & $\mathrm{Au}$ & 5.50E-06 & 5.5E-06 & 5.7E-06 & $1.0 \mathrm{E}-05$ & & & $1.0 \mathrm{E}-05$ & \\
\hline 5 & $\mathrm{~B}$ & & & $1.5 \mathrm{E}-03$ & $3.0 \mathrm{E}-03$ & & & & \\
\hline 56 & $\mathrm{Ba}$ & 4.80E-04 & $3.5 \mathrm{E}-04$ & $3.6 \mathrm{E}-04$ & $5.0 \mathrm{E}-04$ & $4.8 \mathrm{E}-04$ & & $5.0 \mathrm{E}-04$ & $4.0 \mathrm{E}-04$ \\
\hline 4 & $\mathrm{Be}$ & $9.00 \mathrm{E}-07$ & $9.0 \mathrm{E}-07$ & 9.3E-07 & $2.0 \mathrm{E}-06$ & & & $2.0 \mathrm{E}-06$ & \\
\hline 83 & $\mathrm{Bi}$ & $5.00 \mathrm{E}-04$ & $5.0 \mathrm{E}-04$ & $5.2 \mathrm{E}-04$ & $1.0 \mathrm{E}-03$ & & & $5.0 \mathrm{E}-04$ & \\
\hline 97 & $\mathrm{Bk}$ & & & & 2.0E-06 & & & & \\
\hline 35 & $\mathrm{Br}$ & 0.02 & $2.0 \mathrm{E}-02$ & 2.1E-02 & 2.0E-02 & & & $2.0 \mathrm{E}-02$ & \\
\hline 6 & $\mathrm{C}$ & & & & & & & $1.2 \mathrm{E}-02$ & $1.2 \mathrm{E}-02$ \\
\hline 20 & $\mathrm{Ca}$ & $3.00 \mathrm{E}-03$ & $1.0 \mathrm{E}-02$ & $1.0 \mathrm{E}-02$ & 3.0E-03 & 3.0E-03 & & $3.0 \mathrm{E}-03$ & \\
\hline 48 & $\mathrm{Cd}$ & $1.00 \mathrm{E}-03$ & $1.0 \mathrm{E}-03$ & $1.0 \mathrm{E}-03$ & $2.0 \mathrm{E}-03$ & & & $1.0 \mathrm{E}-03$ & \\
\hline 58 & $\mathrm{Ce}$ & $3.00 \mathrm{E}-05$ & $2.0 \mathrm{E}-05$ & $2.1 \mathrm{E}-05$ & 3.0E-05 & $3.0 \mathrm{E}-05$ & $3.00 \mathrm{E}-05$ & 3.0E-05 & $1.0 \mathrm{E}-04$ \\
\hline 98 & Cf & $1.50 \mathrm{E}-06$ & 7.5E-07 & & $2.0 \mathrm{E}-06$ & & & 7.5E-07 & \\
\hline 17 & $\mathrm{Cl}$ & 1.70E-02 & 1.5E-02 & 1.5E-02 & 2.0E-02 & 1.7E-02 & & 2.0E-02 & \\
\hline 96 & $\mathrm{Cm}$ & $2.00 \mathrm{E}-05$ & $2.0 \mathrm{E}-05$ & 2.1E-05 & 2.0E-06 & & & $2.0 \mathrm{E}-06$ & \\
\hline 27 & Co & $3.00 \mathrm{E}-04$ & $2.0 \mathrm{E}-03$ & $2.1 \mathrm{E}-03$ & $2.0 \mathrm{E}-03$ & $3.0 \mathrm{E}-04$ & $3.00 \mathrm{E}-04$ & $2.0 \mathrm{E}-03$ & $1.0 \mathrm{E}-03$ \\
\hline 24 & $\mathrm{Cr}$ & 1.00E-05 & $1.5 \mathrm{E}-03$ & $1.5 \mathrm{E}-03$ & $2.0 \mathrm{E}-03$ & $1.0 \mathrm{E}-05$ & & $2.0 \mathrm{E}-03$ & 2.2E-03 \\
\hline 55 & Cs & 7.90E-03 & 7.0E-03 & 7.2E-03 & $1.0 \mathrm{E}-02$ & 7.9E-03 & 7.90E-03 & $8.0 \mathrm{E}-03$ & $1.2 \mathrm{E}-02$ \\
\hline 29 & $\mathrm{Cu}$ & $2.00 \mathrm{E}-03$ & $1.5 \mathrm{E}-03$ & $1.5 \mathrm{E}-03$ & $2.0 \mathrm{E}-03$ & & & $2.0 \mathrm{E}-03$ & $1.4 \mathrm{E}-02$ \\
\hline 66 & Dy & $3.00 \mathrm{E}-05$ & $2.0 \mathrm{E}-05$ & $2.1 \mathrm{E}-05$ & $6.0 \mathrm{E}-05$ & & & & \\
\hline 68 & Er & $3.00 \mathrm{E}-05$ & 2.0E-05 & 2.1E-05 & $6.0 \mathrm{E}-05$ & & & & \\
\hline 99 & Es & & & & $2.0 \mathrm{E}-06$ & & & & \\
\hline 63 & Eu & $3.00 \mathrm{E}-05$ & $2.0 \mathrm{E}-05$ & $2.1 \mathrm{E}-05$ & $6.0 \mathrm{E}-05$ & & & $2.0 \mathrm{E}-05$ & \\
\hline
\end{tabular}


Table B- 6. Feed-to-Milk Transfer Factors (d/L) from Other Sources (continued)

\begin{tabular}{|c|c|c|c|c|c|c|c|c|c|}
\hline $\mathbf{Z}$ & Element & $\begin{array}{c}\text { PNNL-13421 } \\
\text { (Staven et al. } \\
\text { 2003) } \\
\text { Table 2.8 } \\
\end{array}$ & $\begin{array}{c}\text { NUREG CR-5512 } \\
\text { (Kennedy and Strenge } \\
\text { 1992) } \\
\text { Table 6.18 } \\
\end{array}$ & $\begin{array}{c}\text { ORNL-5786 (Baes } \\
\text { et al. 1984) } \\
\text { Figure } 2.24 \\
\end{array}$ & $\begin{array}{c}\text { NCRP } 123 \text { Vol I } \\
\text { (NCRP 1996) } \\
\text { Table } 5.2 \\
\end{array}$ & IAEA 364 & $\begin{array}{r}\text { CDC 2006 } \\
\text { (Table 8-6) } \\
\end{array}$ & \begin{tabular}{|c|} 
Resrad Version 6 \\
(Yu et al. 2001) \\
Table D.4 \\
\end{tabular} & $\begin{array}{c}\text { Reg Guide } 1.109 \\
\text { (NRC 1977) } \\
\text { Table E-1 } \\
\end{array}$ \\
\hline 9 & $\mathrm{~F}$ & $1.00 \mathrm{E}-03$ & $1.0 \mathrm{E}-03$ & $1.0 \mathrm{E}-03$ & 7.0E-03 & & & 7.0E-03 & \\
\hline 26 & $\mathrm{Fe}$ & $3.00 \mathrm{E}-05$ & 2.5E-04 & 2.6E-04 & $3.0 \mathrm{E}-04$ & 3.0E-05 & & $3.0 \mathrm{E}-04$ & $1.2 \mathrm{E}-03$ \\
\hline 87 & $\mathrm{Fr}$ & & & $2.1 \mathrm{E}-02$ & 8.0E-03 & & & & \\
\hline 31 & $\mathrm{Ga}$ & $5.00 \mathrm{E}-05$ & 5.0E-05 & 5.2E-05 & $1.0 \mathrm{E}-05$ & & & & \\
\hline 64 & Gd & $3.00 \mathrm{E}-05$ & $2.0 \mathrm{E}-05$ & 2.1E-05 & 6.0E-05 & & & $2.0 \mathrm{E}-05$ & \\
\hline 32 & $\mathrm{Ge}$ & & & 7.2E-02 & $1.0 \mathrm{E}-02$ & & & 1.0E-02 & \\
\hline 1 & $\mathrm{H}$ & $1.50 \mathrm{E}-02$ & & & & $1.5 \mathrm{E}-02$ & & $1.0 \mathrm{E}-02$ & $1.0 \mathrm{E}-02$ \\
\hline 105 & $\mathrm{Ha}$ & & & & 5.0E-06 & & & & \\
\hline 2 & $\mathrm{He}$ & & & & 0 & & & & \\
\hline 72 & $\mathrm{Hf}$ & $5.50 \mathrm{E}-07$ & 5.0E-06 & 5.2E-06 & 2.5E-05 & & & & \\
\hline 80 & $\mathrm{Hg}$ & $4.70 \mathrm{E}-04$ & 4.5E-04 & 4.6E-04 & $5.0 \mathrm{E}-04$ & 4.7E-04 & & $5.0 \mathrm{E}-04$ & \\
\hline 67 & Ho & $3.00 \mathrm{E}-05$ & $2.0 \mathrm{E}-05$ & 2.1E-05 & $6.0 \mathrm{E}-05$ & & & $2.0 \mathrm{E}-05$ & \\
\hline 53 & $\mathrm{I}$ & $9.00 \mathrm{E}-03$ & $1.0 \mathrm{E}-02$ & $1.0 \mathrm{E}-02$ & $1.0 \mathrm{E}-02$ & $1.0 \mathrm{E}-02$ & $1.00 \mathrm{E}-02$ & $1.0 \mathrm{E}-02$ & 6.0E-03 \\
\hline 49 & In & $2.00 \mathrm{E}-04$ & $1.0 \mathrm{E}-04$ & $1.0 \mathrm{E}-04$ & 2.0E-04 & & & 2.0E-04 & \\
\hline 77 & $\mathrm{Ir}$ & $2.00 \mathrm{E}-06$ & $2.0 \mathrm{E}-06$ & 2.1E-06 & 2.0E-06 & & & $2.0 \mathrm{E}-06$ & \\
\hline 19 & $\mathrm{~K}$ & $7.20 \mathrm{E}-03$ & 7.0E-03 & 7.2E-03 & 7.0E-03 & 7.2E-03 & & 7.0E-03 & \\
\hline 57 & $\mathrm{La}$ & $2.00 \mathrm{E}-05$ & $2.0 \mathrm{E}-05$ & 2.1E-05 & $6.0 \mathrm{E}-05$ & & & 2.0E-05 & $5.0 \mathrm{E}-06$ \\
\hline 3 & $\mathrm{Li}$ & & & $2.1 \mathrm{E}-02$ & $5.0 \mathrm{E}-02$ & & & & \\
\hline 103 & $\mathrm{Lr}$ & & & & 5.0E-06 & & & & \\
\hline 71 & $\mathrm{Lu}$ & & & $2.1 \mathrm{E}-05$ & $6.0 \mathrm{E}-05$ & & & & \\
\hline 101 & $\mathrm{Md}$ & & & & 5.0E-06 & & & & \\
\hline 12 & $\mathrm{Mg}$ & $3.90 \mathrm{E}-03$ & 4.0E-03 & 4.1E-03 & 8.0E-03 & 3.9E-03 & & & \\
\hline 25 & $\mathrm{Mn}$ & $3.00 \mathrm{E}-05$ & 3.5E-04 & 3.6E-04 & $3.0 \mathrm{E}-04$ & $3.0 \mathrm{E}-05$ & & $3.0 \mathrm{E}-04$ & 2.5E-04 \\
\hline 42 & Mo & $1.70 \mathrm{E}-03$ & $1.5 \mathrm{E}-03$ & $1.5 \mathrm{E}-03$ & $2.0 \mathrm{E}-03$ & 1.7E-03 & & $1.7 \mathrm{E}-03$ & 7.5E-03 \\
\hline 7 & $\mathrm{~N}$ & $2.50 \mathrm{E}-02$ & 2.5E-02 & 2.6E-02 & $1.0 \mathrm{E}-02$ & & & $1.0 \mathrm{E}-02$ & \\
\hline 11 & $\mathrm{Na}$ & $1.60 \mathrm{E}-02$ & 3.5E-02 & 3.6E-02 & 4.0E-02 & $1.6 \mathrm{E}-02$ & & $4.0 \mathrm{E}-02$ & $4.0 \mathrm{E}-02$ \\
\hline 41 & $\mathrm{Nb}$ & 4.10E-07 & $2.0 \mathrm{E}-02$ & 2.1E-02 & $2.0 \mathrm{E}-06$ & 4.1E-07 & 4.10E-07 & $2.0 \mathrm{E}-06$ & $2.5 \mathrm{E}-03$ \\
\hline 60 & $\mathrm{Nd}$ & $3.00 \mathrm{E}-05$ & 2.0E-05 & 2.1E-05 & $6.0 \mathrm{E}-05$ & & & $2.0 \mathrm{E}-05$ & $5.0 \mathrm{E}-06$ \\
\hline 28 & $\mathrm{Ni}$ & $1.60 \mathrm{E}-02$ & $1.0 \mathrm{E}-03$ & $1.0 \mathrm{E}-03$ & $2.0 \mathrm{E}-02$ & 1.6E-02 & & 2.0E-02 & 6.7E-03 \\
\hline 102 & No & & & & 5.0E-06 & & & & \\
\hline 93 & $\mathrm{~Np}$ & 5.00E-06 & $5.0 \mathrm{E}-06$ & $5.2 \mathrm{E}-06$ & $1.0 \mathrm{E}-05$ & 5.0E-06 & & $5.0 \mathrm{E}-06$ & 5.0E-06 \\
\hline
\end{tabular}


Table B- 6. Feed-to-Milk Transfer Factors (d/L) from Other Sources (continued)

\begin{tabular}{|c|c|c|c|c|c|c|c|c|c|}
\hline $\mathbf{Z}$ & Element & $\begin{array}{c}\text { PNNL-13421 } \\
\text { (Staven et al. } \\
\text { 2003) } \\
\text { Table 2.8 } \\
\end{array}$ & $\begin{array}{c}\text { NUREG CR-5512 } \\
\text { (Kennedy and Strenge } \\
\text { 1992) } \\
\text { Table 6.18 } \\
\end{array}$ & $\begin{array}{c}\text { ORNL-5786 (Baes } \\
\text { et al. 1984) } \\
\text { Figure 2.24 } \\
\end{array}$ & $\begin{array}{c}\text { NCRP } 123 \text { Vol I } \\
\text { (NCRP 1996) } \\
\text { Table } 5.2 \\
\end{array}$ & IAEA 364 & $\begin{array}{r}\text { CDC 2006 } \\
\text { (Table 8-6) } \\
\end{array}$ & \begin{tabular}{|c} 
Resrad Version 6 \\
(Yu et al. 2001) \\
Table D.4
\end{tabular} & $\begin{array}{c}\text { Reg Guide } 1.109 \\
\text { (NRC 1977) } \\
\text { Table E-1 } \\
\end{array}$ \\
\hline 76 & Os & $5.00 \mathrm{E}-03$ & $5.0 \mathrm{E}-03$ & $5.2 \mathrm{E}-03$ & $1.0 \mathrm{E}-04$ & & $3.50 \mathrm{E}+00$ & & \\
\hline 15 & $\mathrm{P}$ & $1.60 \mathrm{E}-02$ & $1.5 \mathrm{E}-02$ & $1.5 \mathrm{E}-02$ & $2.0 \mathrm{E}-02$ & $1.6 \mathrm{E}-02$ & $1.60 \mathrm{E}-02$ & 1.6E-02 & 2.5E-02 \\
\hline 91 & $\mathrm{~Pa}$ & $5.00 \mathrm{E}-06$ & 5.0E-06 & 5.2E-06 & 5.0E-06 & & & $5.0 \mathrm{E}-06$ & \\
\hline 82 & $\mathrm{~Pb}$ & $2.60 \mathrm{E}-04$ & $2.5 \mathrm{E}-04$ & $2.6 \mathrm{E}-04$ & 3.0E-04 & & & 3.0E-04 & \\
\hline 46 & $\mathrm{Pd}$ & $1.00 \mathrm{E}-02$ & $1.0 \mathrm{E}-02$ & $1.0 \mathrm{E}-02$ & 1.0E-04 & & & 5.0E-03 & \\
\hline 61 & $\mathrm{Pm}$ & $3.00 \mathrm{E}-05$ & $2.0 \mathrm{E}-05$ & $2.1 \mathrm{E}-05$ & $6.0 \mathrm{E}-05$ & & & 2.0E-05 & \\
\hline 84 & Po & $3.40 \mathrm{E}-04$ & 3.5E-04 & $3.6 \mathrm{E}-04$ & $4.0 \mathrm{E}-04$ & $3.4 \mathrm{E}-04$ & & $3.4 \mathrm{E}-04$ & \\
\hline 59 & $\operatorname{Pr}$ & $3.00 \mathrm{E}-05$ & $2.0 \mathrm{E}-05$ & $2.1 \mathrm{E}-05$ & 6.0E-05 & & & $2.0 \mathrm{E}-05$ & $5.0 \mathrm{E}-06$ \\
\hline 78 & $\mathrm{Pt}$ & & & $5.2 \mathrm{E}-03$ & $1.0 \mathrm{E}-04$ & & & & \\
\hline 94 & $\mathrm{Pu}$ & $1.10 \mathrm{E}-06$ & $1.0 \mathrm{E}-07$ & $1.0 \mathrm{E}-07$ & $1.0 \mathrm{E}-06$ & $1.1 \mathrm{E}-06$ & 1.10E-06 & $1.0 \mathrm{E}-06$ & \\
\hline 88 & $\mathrm{Ra}$ & $1.30 \mathrm{E}-03$ & 4.5E-04 & 4.6E-04 & $1.0 \mathrm{E}-03$ & 1.3E-03 & & $1.0 \mathrm{E}-03$ & \\
\hline 37 & $\mathrm{Rb}$ & $1.20 \mathrm{E}-02$ & $1.0 \mathrm{E}-02$ & $1.0 \mathrm{E}-02$ & $1.0 \mathrm{E}-02$ & $1.2 \mathrm{E}-02$ & & $1.0 \mathrm{E}-02$ & 3.0E-02 \\
\hline 75 & $\mathrm{Re}$ & $1.50 \mathrm{E}-03$ & 1.5E-03 & 1.5E-03 & 2.0E-03 & & & & \\
\hline 104 & $\mathrm{Rf}$ & & & & $2.0 \mathrm{E}-05$ & & & & \\
\hline 45 & $\mathrm{Rh}$ & $1.00 \mathrm{E}-02$ & $1.0 \mathrm{E}-02$ & $1.0 \mathrm{E}-02$ & $5.0 \mathrm{E}-04$ & & & $5.0 \mathrm{E}-03$ & $1.0 \mathrm{E}-02$ \\
\hline 86 & $\mathrm{Rn}$ & & & & 0 & & & 0 & \\
\hline 44 & $\mathrm{Ru}$ & 3.30E-06 & $6.0 \mathrm{E}-07$ & $6.2 \mathrm{E}-07$ & $2.0 \mathrm{E}-05$ & 3.3E-06 & 3.30E-06 & 3.3E-06 & $1.0 \mathrm{E}-06$ \\
\hline 16 & $\mathrm{~S}$ & $1.60 \mathrm{E}-02$ & $1.5 \mathrm{E}-02$ & $1.5 \mathrm{E}-02$ & $2.0 \mathrm{E}-02$ & $1.6 \mathrm{E}-02$ & $1.60 \mathrm{E}-02$ & $2.0 \mathrm{E}-02$ & \\
\hline 51 & $\mathrm{Sb}$ & $2.50 \mathrm{E}-05$ & $1.0 \mathrm{E}-04$ & $1.0 \mathrm{E}-04$ & $1.0 \mathrm{E}-04$ & 2.5E-05 & & $1.0 \mathrm{E}-04$ & \\
\hline 21 & Sc & $5.00 \mathrm{E}-06$ & 5.0E-06 & 5.2E-06 & 6.0E-05 & & & 5.0E-06 & \\
\hline 34 & Se & $4.00 \mathrm{E}-03$ & 4.0E-03 & 4.1E-03 & $1.0 \mathrm{E}-02$ & & & $1.0 \mathrm{E}-02$ & \\
\hline 14 & $\mathrm{Si}$ & $2.00 \mathrm{E}-05$ & $2.0 \mathrm{E}-05$ & 2.1E-05 & 2.0E-05 & & & & \\
\hline 62 & $\mathrm{Sm}$ & $3.00 \mathrm{E}-05$ & $2.0 \mathrm{E}-05$ & $2.1 \mathrm{E}-05$ & $6.0 \mathrm{E}-05$ & & & $2.0 \mathrm{E}-05$ & \\
\hline 50 & Sn & $1.00 \mathrm{E}-03$ & $1.0 \mathrm{E}-03$ & $1.0 \mathrm{E}-03$ & $1.0 \mathrm{E}-03$ & & & $1.0 \mathrm{E}-03$ & \\
\hline 38 & $\mathrm{Sr}$ & $2.80 \mathrm{E}-03$ & 1.5E-03 & 1.5E-03 & $2.0 \mathrm{E}-03$ & $2.8 \mathrm{E}-03$ & & $2.0 \mathrm{E}-03$ & 8.0E-04 \\
\hline 73 & $\mathrm{Ta}$ & 4.10E-07 & 3.0E-06 & 3.1E-06 & 5.0E-06 & & & 5.0E-06 & \\
\hline 65 & $\mathrm{~Tb}$ & $3.00 \mathrm{E}-05$ & $2.0 \mathrm{E}-05$ & $2.1 \mathrm{E}-05$ & $6.0 \mathrm{E}-05$ & & & 2.0E-05 & \\
\hline 43 & Tc & $1.40 \mathrm{E}-04$ & $1.0 \mathrm{E}-02$ & $1.0 \mathrm{E}-02$ & $1.0 \mathrm{E}-03$ & 2.3E-05 & 2.30E-05 & $1.0 \mathrm{E}-03$ & 2.5E-02 \\
\hline 52 & $\mathrm{Te}$ & $4.50 \mathrm{E}-04$ & $2.0 \mathrm{E}-04$ & 2.1E-04 & $5.0 \mathrm{E}-04$ & 4.5E-04 & & $5.0 \mathrm{E}-04$ & $1.0 \mathrm{E}-03$ \\
\hline 90 & Th & $5.00 \mathrm{E}-06$ & 5.0E-06 & 5.2E-06 & $5.0 \mathrm{E}-06$ & & 5.00E-06 & $5.0 \mathrm{E}-06$ & \\
\hline 22 & $\mathrm{Ti}$ & & & $1.0 \mathrm{E}-02$ & $1.0 \mathrm{E}-02$ & & & & \\
\hline
\end{tabular}


Table B- 6. Feed-to-Milk Transfer Factors (d/L) from Other Sources (continued)

\begin{tabular}{|c|c|c|c|c|c|c|c|c|c|}
\hline $\mathbf{Z}$ & Element & $\begin{array}{c}\text { PNNL-13421 } \\
\text { (Staven et al. } \\
\text { 2003) } \\
\text { Table 2.8 } \\
\end{array}$ & $\begin{array}{c}\text { NUREG CR-5512 } \\
\text { (Kennedy and Strenge } \\
\text { 1992) } \\
\text { Table 6.18 } \\
\end{array}$ & $\begin{array}{c}\text { ORNL-5786 (Baes } \\
\text { et al. 1984) } \\
\text { Figure 2.24 } \\
\end{array}$ & $\begin{array}{c}\text { NCRP } 123 \text { Vol I } \\
\text { (NCRP 1996) } \\
\text { Table } 5.2 \\
\end{array}$ & IAEA 364 & $\begin{array}{r}\text { CDC 2006 } \\
\text { (Table 8-6) }\end{array}$ & $\begin{array}{c}\text { Resrad Version } 6 \\
\text { (Yu et al. 2001) } \\
\text { Table D.4 } \\
\end{array}$ & $\begin{array}{c}\text { Reg Guide } 1.109 \\
\text { (NRC 1977) } \\
\text { Table E-1 } \\
\end{array}$ \\
\hline 81 & $\mathrm{Tl}$ & $2.00 \mathrm{E}-03$ & $2.0 \mathrm{E}-03$ & $2.1 \mathrm{E}-03$ & $1.0 \mathrm{E}-03$ & & & 3.0E-03 & \\
\hline 69 & $\mathrm{Tm}$ & & & $2.1 \mathrm{E}-05$ & $6.0 \mathrm{E}-05$ & & & & \\
\hline 92 & $\mathrm{U}$ & 4.00E-04 & $6.0 \mathrm{E}-04$ & $6.2 \mathrm{E}-04$ & $4.0 \mathrm{E}-04$ & $4.0 \mathrm{E}-04$ & 4.00E-04 & $6.0 \mathrm{E}-04$ & \\
\hline 23 & $\mathrm{~V}$ & & & 2.1E-05 & $5.0 \mathrm{E}-04$ & & & & \\
\hline 74 & $\mathrm{~W}$ & $3.00 \mathrm{E}-04$ & $3.0 \mathrm{E}-04$ & $3.1 \mathrm{E}-04$ & $3.0 \mathrm{E}-04$ & & & $3.0 \mathrm{E}-04$ & $5.0 \mathrm{E}-04$ \\
\hline 39 & $\mathrm{Y}$ & 2.00E-05 & $2.0 \mathrm{E}-05$ & $2.1 \mathrm{E}-05$ & $6.0 \mathrm{E}-05$ & & $2.00 \mathrm{E}-05$ & 2.0E-05 & $1.0 \mathrm{E}-05$ \\
\hline 70 & $\mathrm{Yb}$ & & & $2.1 \mathrm{E}-05$ & $6.0 \mathrm{E}-05$ & & & & \\
\hline 30 & $\mathrm{Zn}$ & $1.00 \mathrm{E}-02$ & $1.0 \mathrm{E}-02$ & $1.0 \mathrm{E}-02$ & $1.0 \mathrm{E}-02$ & & $1.00 \mathrm{E}-02$ & $1.0 \mathrm{E}-02$ & 3.9E-02 \\
\hline 40 & $\mathrm{Zr}$ & $5.50 \mathrm{E}-07$ & $3.0 \mathrm{E}-05$ & $3.1 \mathrm{E}-05$ & $6.0 \mathrm{E}-07$ & 5.5E-07 & $5.50 \mathrm{E}-07$ & $6.0 \mathrm{E}-07$ & $5.0 \mathrm{E}-06$ \\
\hline
\end{tabular}


Table B- 7. Feed-to-Meat Bioaccumulation Factors (d/kg) from Other Sources

\begin{tabular}{|c|c|c|c|c|c|c|c|c|c|}
\hline $\mathbf{Z}$ & Element & $\begin{array}{c}\text { PNNL-13421 } \\
\text { (Staven et al. 2003) } \\
\text { Table } 2.6\end{array}$ & $\begin{array}{l}\text { NUREG CR-5512 } \\
\text { (Kennedy and Strenge } \\
\text { 1992) Table } 6.18\end{array}$ & $\begin{array}{c}\text { ORNL-5786 } \\
\text { (Baes et al. 1984) } \\
\text { Figure 2.25 } \\
\end{array}$ & $\begin{array}{c}\text { NCRP } 123 \text { Vol I } \\
\text { (NCRP 1996) } \\
\text { Table } 5.2\end{array}$ & IAEA 364 & $\begin{array}{c}\text { RESRAD Version } 6 \\
\text { (Yu et al. 2001) } \\
\text { Table D.4 }\end{array}$ & $\begin{array}{c}\text { CDC } 2006 \\
\text { (Table 8-6) }\end{array}$ & $\begin{array}{c}\text { Reg Guide } 1.109 \\
\text { (NRC 1977) } \\
\text { Table E-1 }\end{array}$ \\
\hline 89 & Ac & $4.00 \mathrm{E}-04$ & 2.5E-05 & 2.5E-05 & $2.0 \mathrm{E}-05$ & & $2.00 \mathrm{E}-05$ & & \\
\hline 47 & $\mathrm{Ag}$ & $3.00 \mathrm{E}-03$ & $3.0 \mathrm{E}-03$ & $3.0 \mathrm{E}-03$ & $3.0 \mathrm{E}-03$ & $3.00 \mathrm{E}-03$ & $3.00 \mathrm{E}-03$ & & 1.7E-02 \\
\hline 13 & $\mathrm{Al}$ & & & $1.5 \mathrm{E}-03$ & $5.0 \mathrm{E}-04$ & & $5.00 \mathrm{E}-04$ & & \\
\hline 95 & Am & $4.00 \mathrm{E}-05$ & 3.5E-06 & 3.5E-06 & 5.0E-05 & $4.00 \mathrm{E}-05$ & $5.00 \mathrm{E}-05$ & $4.00 \mathrm{E}-05$ & \\
\hline 33 & As & $2.00 \mathrm{E}-03$ & $2.0 \mathrm{E}-03$ & $2.0 \mathrm{E}-03$ & $2.0 \mathrm{E}-02$ & & $1.50 \mathrm{E}-03$ & & \\
\hline 85 & At & & & $1.0 \mathrm{E}-02$ & $1.0 \mathrm{E}-02$ & & & & \\
\hline 79 & $\mathrm{Au}$ & $5.00 \mathrm{E}-03$ & 8.0E-03 & $8.0 \mathrm{E}-03$ & $5.0 \mathrm{E}-03$ & & 5.00E-03 & & \\
\hline 5 & $\mathrm{~B}$ & & & $8.0 \mathrm{E}-04$ & $8.0 \mathrm{E}-04$ & & & & \\
\hline 56 & $\mathrm{Ba}$ & $2.00 \mathrm{E}-04$ & $1.5 \mathrm{E}-04$ & $1.5 \mathrm{E}-04$ & $2.0 \mathrm{E}-04$ & 2.00E-04 & $2.00 \mathrm{E}-04$ & & $3.2 \mathrm{E}-03$ \\
\hline 4 & $\mathrm{Be}$ & $1.00 \mathrm{E}-03$ & $1.0 \mathrm{E}-03$ & $1.0 \mathrm{E}-03$ & $5.0 \mathrm{E}-03$ & & $1.00 \mathrm{E}-03$ & & \\
\hline 83 & $\mathrm{Bi}$ & $4.00 \mathrm{E}-04$ & $4.0 \mathrm{E}-04$ & $4.0 \mathrm{E}-04$ & $2.0 \mathrm{E}-03$ & & $2.00 \mathrm{E}-03$ & & \\
\hline 97 & $\mathrm{Bk}$ & & & & $2.5 \mathrm{E}-05$ & & & & \\
\hline 35 & $\mathrm{Br}$ & $2.50 \mathrm{E}-02$ & $2.5 \mathrm{E}-02$ & $2.5 \mathrm{E}-02$ & $5.0 \mathrm{E}-02$ & & $2.00 \mathrm{E}-02$ & & \\
\hline 6 & $\mathrm{C}$ & & & & & & $3.10 \mathrm{E}-02$ & & $3.1 \mathrm{E}-02$ \\
\hline 20 & $\mathrm{Ca}$ & $2.00 \mathrm{E}-03$ & $7.0 \mathrm{E}-04$ & $7.0 \mathrm{E}-04$ & $2.0 \mathrm{E}-03$ & $2.00 \mathrm{E}-03$ & $1.60 \mathrm{E}-03$ & & \\
\hline 48 & $\mathrm{Cd}$ & $4.00 \mathrm{E}-04$ & 5.5E-04 & 5.5E-04 & $1.0 \mathrm{E}-03$ & $4.00 \mathrm{E}-04$ & $4.00 \mathrm{E}-04$ & & \\
\hline 58 & $\mathrm{Ce}$ & $2.00 \mathrm{E}-05$ & 7.5E-04 & 7.5E-04 & $2.0 \mathrm{E}-05$ & $2.00 \mathrm{E}-05$ & $2.00 \mathrm{E}-05$ & $2.00 \mathrm{E}-05$ & $1.2 \mathrm{E}-03$ \\
\hline 98 & $\mathrm{Cf}$ & $4.00 \mathrm{E}-05$ & $5.0 \mathrm{E}-03$ & & $6.0 \mathrm{E}-05$ & & $6.00 \mathrm{E}-05$ & & \\
\hline 17 & $\mathrm{Cl}$ & $2.00 \mathrm{E}-02$ & 8.0E-02 & $8.0 \mathrm{E}-02$ & $4.0 \mathrm{E}-02$ & $2.00 \mathrm{E}-02$ & $6.00 \mathrm{E}-02$ & & \\
\hline 96 & $\mathrm{Cm}$ & $4.00 \mathrm{E}-05$ & $3.5 \mathrm{E}-06$ & $3.5 \mathrm{E}-06$ & $2.0 \mathrm{E}-05$ & & $2.00 \mathrm{E}-05$ & & \\
\hline 27 & Co & $1.00 \mathrm{E}-02$ & $2.0 \mathrm{E}-02$ & $2.0 \mathrm{E}-02$ & $3.0 \mathrm{E}-02$ & $1.00 \mathrm{E}-02$ & $2.00 \mathrm{E}-02$ & $1.00 \mathrm{E}-02$ & 1.3E-02 \\
\hline 24 & $\mathrm{Cr}$ & $9.00 \mathrm{E}-03$ & $5.5 \mathrm{E}-03$ & $5.5 \mathrm{E}-03$ & $3.0 \mathrm{E}-02$ & $9.00 \mathrm{E}-03$ & $9.00 \mathrm{E}-03$ & & $2.4 \mathrm{E}-03$ \\
\hline 55 & Cs & $5.00 \mathrm{E}-02$ & $2.0 \mathrm{E}-02$ & $2.0 \mathrm{E}-02$ & $5.0 \mathrm{E}-02$ & $5.00 \mathrm{E}-02$ & $3.00 \mathrm{E}-02$ & $5.00 \mathrm{E}-02$ & $4.0 \mathrm{E}-03$ \\
\hline 29 & $\mathrm{Cu}$ & $9.00 \mathrm{E}-03$ & $1.0 \mathrm{E}-02$ & $1.0 \mathrm{E}-02$ & $1.0 \mathrm{E}-02$ & $9.00 \mathrm{E}-03$ & $1.00 \mathrm{E}-02$ & & $8.0 \mathrm{E}-03$ \\
\hline 66 & Dy & $2.00 \mathrm{E}-05$ & $5.5 \mathrm{E}-03$ & $5.5 \mathrm{E}-03$ & $2.0 \mathrm{E}-03$ & & & & \\
\hline
\end{tabular}


Table B- 7. Feed-to-Meat Bioaccumulation Factors (d/kg) from Other Sources (continued)

\begin{tabular}{|c|c|c|c|c|c|c|c|c|c|}
\hline $\mathbf{Z}$ & Element & $\begin{array}{c}\text { PNNL-13421 } \\
\text { (Staven et al. 2003) } \\
\text { Table 2.6 } \\
\end{array}$ & $\begin{array}{c}\text { NUREG CR-5512 } \\
\text { (Kennedy and Strenge } \\
\text { 1992) Table } 6.18\end{array}$ & \begin{tabular}{|c} 
ORNL-5786 \\
(Baes et al. 1984) \\
Figure 2.25 \\
\end{tabular} & $\begin{array}{c}\text { NCRP } 123 \text { Vol I } \\
\text { (NCRP 1996) } \\
\text { Table } 5.2 \\
\end{array}$ & IAEA 364 & \begin{tabular}{|c|} 
RESRAD Version 6 \\
(Yu et al. 2001) \\
Table D.4
\end{tabular} & $\begin{array}{l}\text { CDC } 2006 \\
\text { (Table 8-6) }\end{array}$ & $\begin{array}{c}\text { Reg Guide } 1.109 \\
\text { (NRC 1977) } \\
\text { Table E-1 } \\
\end{array}$ \\
\hline 68 & Er & $2.00 \mathrm{E}-05$ & 4.0E-03 & 4.0E-03 & $2.0 \mathrm{E}-03$ & & & & \\
\hline 99 & Es & & & & 2.5E-05 & & & & \\
\hline 63 & $\mathrm{Eu}$ & $2.00 \mathrm{E}-05$ & $5.0 \mathrm{E}-03$ & $5.0 \mathrm{E}-03$ & $2.0 \mathrm{E}-03$ & & $2.00 \mathrm{E}-03$ & & \\
\hline 9 & $\mathrm{~F}$ & $1.50 \mathrm{E}-01$ & $1.5 \mathrm{E}-01$ & $1.5 \mathrm{E}-01$ & $2.0 \mathrm{E}-02$ & & $2.00 \mathrm{E}-02$ & & \\
\hline 26 & $\mathrm{Fe}$ & $2.00 \mathrm{E}-02$ & $2.0 \mathrm{E}-02$ & $2.0 \mathrm{E}-02$ & $3.0 \mathrm{E}-02$ & $2.00 \mathrm{E}-02$ & $2.00 \mathrm{E}-02$ & & 4.0E-02 \\
\hline 100 & $\mathrm{Fm}$ & & & & $2.0 \mathrm{E}-04$ & & & & \\
\hline 87 & $\mathrm{Fr}$ & & & 2.5E-03 & $3.0 \mathrm{E}-02$ & & & & \\
\hline 31 & $\mathrm{Ga}$ & $5.00 \mathrm{E}-04$ & 5.0E-04 & $5.0 \mathrm{E}-04$ & $3.0 \mathrm{E}-04$ & & & & \\
\hline 64 & Gd & $2.00 \mathrm{E}-05$ & 3.5E-03 & 3.5E-03 & $2.0 \mathrm{E}-03$ & & $2.00 \mathrm{E}-03$ & & \\
\hline 32 & $\mathrm{Ge}$ & & & 7.0E-01 & $2.0 \mathrm{E}-01$ & & $2.00 \mathrm{E}-01$ & & \\
\hline 1 & $\mathrm{H}$ & & & & & & $1.20 \mathrm{E}-02$ & & $1.2 \mathrm{E}-02$ \\
\hline 105 & На & & & & 5.0E-06 & & & & \\
\hline 72 & $\mathrm{Hf}$ & $1.00 \mathrm{E}-03$ & $1.0 \mathrm{E}-03$ & $1.0 \mathrm{E}-03$ & 4.0E-04 & & & & \\
\hline 80 & $\mathrm{Hg}$ & $2.50 \mathrm{E}-01$ & 2.5E-01 & 2.5E-01 & $1.0 \mathrm{E}-02$ & & $1.00 \mathrm{E}-01$ & & \\
\hline 67 & Ho & $2.00 \mathrm{E}-05$ & 4.5E-03 & 4.5E-03 & $2.0 \mathrm{E}-03$ & & $2.00 \mathrm{E}-03$ & & \\
\hline 53 & $\mathrm{I}$ & $4.00 \mathrm{E}-02$ & 7.0E-03 & $7.0 \mathrm{E}-03$ & $4.0 \mathrm{E}-02$ & 4.00E-02 & $7.00 \mathrm{E}-03$ & $4.00 \mathrm{E}-02$ & 2.9E-03 \\
\hline 49 & In & 8.00E-03 & 8.0E-03 & 8.0E-03 & 4.0E-03 & & $4.00 \mathrm{E}-03$ & & \\
\hline 77 & Ir & $1.50 \mathrm{E}-03$ & $1.5 \mathrm{E}-03$ & $1.5 \mathrm{E}-03$ & $2.0 \mathrm{E}-03$ & & $2.00 \mathrm{E}-03$ & & \\
\hline 19 & $\mathrm{~K}$ & $2.00 \mathrm{E}-02$ & $2.0 \mathrm{E}-02$ & $2.0 \mathrm{E}-02$ & $2.0 \mathrm{E}-02$ & 2.00E-02 & $2.00 \mathrm{E}-02$ & & \\
\hline 57 & $\mathrm{La}$ & $2.00 \mathrm{E}-03$ & $3.0 \mathrm{E}-04$ & 3.0E-04 & $2.0 \mathrm{E}-03$ & & $2.00 \mathrm{E}-03$ & & $2.0 \mathrm{E}-04$ \\
\hline 3 & $\mathrm{Li}$ & & & $1.0 \mathrm{E}-02$ & 2.0E-02 & & & & \\
\hline 103 & $\mathrm{Lr}$ & & & & $2.0 \mathrm{E}-04$ & & & & \\
\hline 71 & $\mathrm{Lu}$ & & & 4.5E-03 & $2.0 \mathrm{E}-03$ & & & & \\
\hline 12 & $\mathrm{Mg}$ & $2.00 \mathrm{E}-02$ & $5.0 \mathrm{E}-03$ & $5.0 \mathrm{E}-03$ & $3.0 \mathrm{E}-03$ & $2.00 \mathrm{E}-02$ & & & \\
\hline 25 & $\mathrm{Mn}$ & $5.00 \mathrm{E}-04$ & 4.0E-04 & 4.0E-04 & $1.0 \mathrm{E}-03$ & $5.00 \mathrm{E}-04$ & $5.00 \mathrm{E}-04$ & & 8.0E-04 \\
\hline 42 & Mo & $1.00 \mathrm{E}-03$ & $6.0 \mathrm{E}-03$ & $6.0 \mathrm{E}-03$ & $1.0 \mathrm{E}-03$ & $1.00 \mathrm{E}-03$ & $1.00 \mathrm{E}-03$ & & 8.0E-03 \\
\hline 7 & $\mathrm{~N}$ & 7.50E-02 & 7.5E-02 & 7.5E-02 & $1.0 \mathrm{E}-02$ & & $1.00 \mathrm{E}-02$ & & \\
\hline
\end{tabular}


Table B- 7. Feed-to-Meat Bioaccumulation Factors (d/kg) from Other Sources (continued)

\begin{tabular}{|c|c|c|c|c|c|c|c|c|c|}
\hline $\mathbf{Z}$ & Element & $\begin{array}{c}\text { PNNL-13421 } \\
\text { (Staven et al. 2003) } \\
\text { Table 2.6 } \\
\end{array}$ & $\begin{array}{c}\text { NUREG CR-5512 } \\
\text { (Kennedy and Strenge } \\
\text { 1992) Table } 6.18\end{array}$ & \begin{tabular}{|c} 
ORNL-5786 \\
(Baes et al. 1984) \\
Figure 2.25 \\
\end{tabular} & $\begin{array}{c}\text { NCRP } 123 \text { Vol I } \\
\text { (NCRP 1996) } \\
\text { Table } 5.2 \\
\end{array}$ & IAEA 364 & $\begin{array}{c}\text { RESRAD Version } 6 \\
\text { (Yu et al. 2001) } \\
\text { Table D.4 }\end{array}$ & $\begin{array}{l}\text { CDC } 2006 \\
\text { (Table 8-6) }\end{array}$ & $\begin{array}{c}\text { Reg Guide } 1.109 \\
\text { (NRC 1977) } \\
\text { Table E-1 } \\
\end{array}$ \\
\hline 11 & $\mathrm{Na}$ & 8.00E-02 & 5.5E-02 & 5.5E-02 & 8.0E-02 & 8.00E-02 & 8.00E-02 & & 3.0E-02 \\
\hline 41 & $\mathrm{Nb}$ & $3.00 \mathrm{E}-07$ & 2.5E-01 & 2.5E-01 & $3.0 \mathrm{E}-07$ & $3.00 \mathrm{E}-07$ & $3.00 \mathrm{E}-07$ & $3.00 \mathrm{E}-07$ & $2.8 \mathrm{E}-01$ \\
\hline 60 & $\mathrm{Nd}$ & 2.00E-05 & 3.0E-04 & 3.0E-04 & 2.0E-03 & & 2.00E-03 & & 3.3E-03 \\
\hline 28 & $\mathrm{Ni}$ & $5.00 \mathrm{E}-03$ & $6.0 \mathrm{E}-03$ & $6.0 \mathrm{E}-03$ & 5.0E-03 & $5.00 \mathrm{E}-03$ & $5.00 \mathrm{E}-03$ & & 5.3E-02 \\
\hline 102 & No & & & & $2.0 \mathrm{E}-04$ & & & & \\
\hline 93 & $\mathrm{~Np}$ & $1.00 \mathrm{E}-03$ & 5.5E-05 & 5.5E-05 & $1.0 \mathrm{E}-03$ & $1.00 \mathrm{E}-03$ & $1.00 \mathrm{E}-03$ & & $2.0 \mathrm{E}-04$ \\
\hline 76 & Os & $4.00 \mathrm{E}-01$ & 4.0E-01 & 4.0E-01 & $2.0 \mathrm{E}-03$ & & & & \\
\hline 15 & $\mathrm{P}$ & $5.00 \mathrm{E}-02$ & 5.5E-02 & 5.5E-02 & 5.0E-02 & $5.00 \mathrm{E}-02$ & $5.00 \mathrm{E}-02$ & $2.00 \mathrm{E}-01$ & 4.6E-02 \\
\hline 91 & $\mathrm{~Pa}$ & $4.00 \mathrm{E}-05$ & $1.0 \mathrm{E}-05$ & $1.0 \mathrm{E}-05$ & $5.0 \mathrm{E}-06$ & & $5.00 \mathrm{E}-03$ & & \\
\hline 82 & $\mathrm{~Pb}$ & $4.00 \mathrm{E}-04$ & $3.0 \mathrm{E}-04$ & 3.0E-04 & 8.0E-04 & $4.00 \mathrm{E}-04$ & 8.00E-04 & & \\
\hline 46 & $\mathrm{Pd}$ & $4.00 \mathrm{E}-03$ & $4.0 \mathrm{E}-03$ & $4.0 \mathrm{E}-03$ & $2.0 \mathrm{E}-04$ & & $1.00 \mathrm{E}-03$ & & \\
\hline 61 & $\mathrm{Pm}$ & $2.00 \mathrm{E}-05$ & 5.0E-03 & $5.0 \mathrm{E}-03$ & $2.0 \mathrm{E}-03$ & & $2.00 \mathrm{E}-03$ & & \\
\hline 84 & Po & $5.00 \mathrm{E}-03$ & $3.0 \mathrm{E}-04$ & 9.5E-05 & $5.0 \mathrm{E}-03$ & $5.00 \mathrm{E}-03$ & $5.00 \mathrm{E}-03$ & & \\
\hline 59 & $\operatorname{Pr}$ & $2.00 \mathrm{E}-05$ & 3.0E-04 & 3.0E-04 & 2.0E-03 & & $2.00 \mathrm{E}-03$ & & 4.7E-03 \\
\hline 78 & $\mathrm{Pt}$ & & & 4.0E-03 & 2.0E-04 & & & & \\
\hline 94 & $\mathrm{Pu}$ & $1.00 \mathrm{E}-05$ & $5.0 \mathrm{E}-07$ & $5.0 \mathrm{E}-07$ & $1.0 \mathrm{E}-04$ & $1.00 \mathrm{E}-05$ & $1.00 \mathrm{E}-04$ & $1.00 \mathrm{E}-05$ & \\
\hline 88 & $\mathrm{Ra}$ & $9.00 \mathrm{E}-04$ & 2.5E-04 & 2.5E-04 & $1.0 \mathrm{E}-03$ & $9.00 \mathrm{E}-04$ & $1.00 \mathrm{E}-03$ & & \\
\hline 37 & $\mathrm{Rb}$ & $1.00 \mathrm{E}-02$ & $1.5 \mathrm{E}-02$ & $1.5 \mathrm{E}-02$ & 3.0E-02 & $1.00 \mathrm{E}-02$ & $1.50 \mathrm{E}-02$ & & $3.1 \mathrm{E}-02$ \\
\hline 75 & $\mathrm{Re}$ & 8.00E-03 & 8.0E-03 & 8.0E-03 & $1.0 \mathrm{E}-02$ & & & & \\
\hline 45 & $\mathrm{Rh}$ & $2.00 \mathrm{E}-03$ & $2.0 \mathrm{E}-03$ & $2.0 \mathrm{E}-03$ & 2.0E-03 & & $1.00 \mathrm{E}-03$ & & $1.5 \mathrm{E}-03$ \\
\hline 86 & $\mathrm{Rn}$ & & & & 0 & & 0 & & \\
\hline 44 & $\mathrm{Ru}$ & $5.00 \mathrm{E}-02$ & $2.0 \mathrm{E}-03$ & $2.0 \mathrm{E}-03$ & $2.0 \mathrm{E}-03$ & $5.00 \mathrm{E}-02$ & $2.00 \mathrm{E}-03$ & $5.00 \mathrm{E}-02$ & 4.0E-01 \\
\hline 16 & $S$ & $2.00 \mathrm{E}-01$ & $1.0 \mathrm{E}-01$ & $1.0 \mathrm{E}-01$ & 2.0E-01 & & $2.00 \mathrm{E}-01$ & $2.00 \mathrm{E}-01$ & \\
\hline 51 & $\mathrm{Sb}$ & $1.00 \mathrm{E}-03$ & $1.0 \mathrm{E}-03$ & $1.0 \mathrm{E}-03$ & $1.0 \mathrm{E}-03$ & 4.00E-05 & $1.00 \mathrm{E}-03$ & & \\
\hline 21 & Sc & $1.50 \mathrm{E}-02$ & 1.5E-02 & 1.5E-02 & $2.0 \mathrm{E}-03$ & & $1.50 \mathrm{E}-02$ & & \\
\hline 34 & Se & $1.50 \mathrm{E}-02$ & $1.5 \mathrm{E}-02$ & $1.5 \mathrm{E}-02$ & $1.0 \mathrm{E}-01$ & & $1.00 \mathrm{E}-01$ & & \\
\hline 14 & $\mathrm{Si}$ & $4.00 \mathrm{E}-05$ & $4.0 \mathrm{E}-05$ & $4.0 \mathrm{E}-05$ & 3.0E-04 & & & & \\
\hline
\end{tabular}


Table B- 7. Feed-to-Meat Bioaccumulation Factors (d/kg) from Other Sources (continued)

\begin{tabular}{|c|c|c|c|c|c|c|c|c|c|}
\hline $\mathbf{Z}$ & Element & $\begin{array}{c}\text { PNNL-13421 } \\
\text { (Staven et al. 2003) } \\
\text { Table } 2.6 \\
\end{array}$ & $\begin{array}{c}\text { NUREG CR-5512 } \\
\text { (Kennedy and Strenge } \\
\text { 1992) Table } 6.18\end{array}$ & \begin{tabular}{|c} 
ORNL-5786 \\
(Baes et al. 1984) \\
Figure 2.25 \\
\end{tabular} & $\begin{array}{c}\text { NCRP } 123 \text { Vol I } \\
\text { (NCRP 1996) } \\
\text { Table } 5.2 \\
\end{array}$ & IAEA 364 & $\begin{array}{c}\text { RESRAD Version } 6 \\
\text { (Yu et al. 2001) } \\
\text { Table D.4 }\end{array}$ & $\begin{array}{l}\text { CDC } 2006 \\
\text { (Table 8-6) }\end{array}$ & $\begin{array}{c}\text { Reg Guide } 1.109 \\
\text { (NRC 1977) } \\
\text { Table E-1 } \\
\end{array}$ \\
\hline 62 & $\mathrm{Sm}$ & $2.00 \mathrm{E}-05$ & $5.0 \mathrm{E}-03$ & $5.0 \mathrm{E}-03$ & $2.0 \mathrm{E}-03$ & & $2.00 \mathrm{E}-03$ & & \\
\hline 50 & Sn & 8.00E-02 & 8.0E-02 & 8.0E-02 & $1.0 \mathrm{E}-02$ & & $1.00 \mathrm{E}-02$ & & \\
\hline 38 & $\mathrm{Sr}$ & 8.00E-03 & $3.0 \mathrm{E}-04$ & $3.0 \mathrm{E}-04$ & $1.0 \mathrm{E}-02$ & 8.00E-03 & 8.00E-03 & 8.00E-03 & $6.0 \mathrm{E}-04$ \\
\hline 73 & $\mathrm{Ta}$ & $3.00 \mathrm{E}-07$ & $6.0 \mathrm{E}-04$ & $6.0 \mathrm{E}-04$ & 5.0E-06 & & $5.00 \mathrm{E}-06$ & & \\
\hline 65 & $\mathrm{~Tb}$ & $2.00 \mathrm{E}-05$ & 4.5E-03 & 4.5E-03 & $2.0 \mathrm{E}-03$ & & $2.00 \mathrm{E}-03$ & & \\
\hline 43 & Tc & $1.00 \mathrm{E}-04$ & 8.5E-03 & 8.5E-03 & $1.0 \mathrm{E}-04$ & $1.00 \mathrm{E}-04$ & $1.00 \mathrm{E}-04$ & $1.00 \mathrm{E}-04$ & 4.0E-01 \\
\hline 52 & $\mathrm{Te}$ & 7.00E-03 & $1.5 \mathrm{E}-02$ & $1.5 \mathrm{E}-02$ & 7.0E-03 & 7.00E-03 & $7.00 \mathrm{E}-03$ & & 7.7E-02 \\
\hline 90 & Th & $4.00 \mathrm{E}-05$ & $6.0 \mathrm{E}-06$ & $6.0 \mathrm{E}-06$ & $1.0 \mathrm{E}-04$ & & $1.00 \mathrm{E}-04$ & $4.00 \mathrm{E}-05$ & \\
\hline 22 & $\mathrm{Ti}$ & & & 3.0E-02 & $2.0 \mathrm{E}-02$ & & & & \\
\hline 81 & $\mathrm{Tl}$ & $4.00 \mathrm{E}-02$ & 4.0E-02 & 4.0E-02 & $2.0 \mathrm{E}-02$ & & $2.00 \mathrm{E}-02$ & & \\
\hline 69 & $\mathrm{Tm}$ & & & 4.5E-03 & $2.0 \mathrm{E}-03$ & & & & \\
\hline 92 & $\mathrm{U}$ & $3.00 \mathrm{E}-04$ & 2.0E-04 & 2.0E-04 & 8.0E-04 & 3.00E-04 & $3.40 \mathrm{E}-04$ & $3.00 \mathrm{E}-04$ & \\
\hline 23 & $\mathrm{~V}$ & & & 2.5E-03 & $1.0 \mathrm{E}-02$ & & & & \\
\hline 74 & $\mathrm{~W}$ & $4.00 \mathrm{E}-02$ & 4.5E-02 & 4.5E-02 & 4.0E-02 & 4.00E-02 & $4.00 \mathrm{E}-02$ & & 1.3E-03 \\
\hline 39 & $\mathrm{Y}$ & $1.00 \mathrm{E}-03$ & $3.0 \mathrm{E}-04$ & $3.0 \mathrm{E}-04$ & $2.0 \mathrm{E}-03$ & $1.00 \mathrm{E}-03$ & $2.00 \mathrm{E}-03$ & $1.00 \mathrm{E}-03$ & 4.6E-03 \\
\hline 70 & $\mathrm{Yb}$ & & & 4.0E-03 & $2.0 \mathrm{E}-03$ & & & & \\
\hline 30 & $\mathrm{Zn}$ & $1.00 \mathrm{E}-01$ & $1.0 \mathrm{E}-01$ & $1.0 \mathrm{E}-01$ & $1.0 \mathrm{E}-01$ & $1.00 \mathrm{E}-01$ & $1.00 \mathrm{E}-01$ & $1.00 \mathrm{E}-01$ & $3.0 \mathrm{E}-02$ \\
\hline 40 & $\mathrm{Zr}$ & $1.00 \mathrm{E}-06$ & 5.5E-03 & 5.5E-03 & $1.0 \mathrm{E}-06$ & $1.00 \mathrm{E}-06$ & $1.00 \mathrm{E}-06$ & $1.00 \mathrm{E}-06$ & 3.4E-02 \\
\hline
\end{tabular}


Table B- 8. Water-to-Fish Bioaccumulation Factors (L/kg) from Other Sources

\begin{tabular}{|c|c|c|c|c|c|c|c|c|}
\hline $\mathbf{Z}$ & Element & $\begin{array}{c}\text { PNNL-13421 (Staven et al. } \\
\text { 2003) Table } 2.10\end{array}$ & $\begin{array}{c}\text { NUREG CR-5512 } \\
\text { (Kennedy and Strenge } \\
\text { 1992) Table } 6.19 \\
\end{array}$ & $\begin{array}{c}\text { NCRP } 123 \\
\text { Vol I } \\
\text { (NCRP } \\
\text { 1996) Table } \\
5.2 \\
\end{array}$ & $\begin{array}{c}\text { RESRAD } \\
\text { Version } 6 \text { (Yu } \\
\text { et al. } \\
\text { 2001)Table } \\
\text { D.5 } \\
\end{array}$ & $\begin{array}{c}\text { Reg Guide } \\
1.109 \text { (NRC } \\
\text { 1977) Table } \\
\text { A-3 } \\
\end{array}$ & $\begin{array}{r}\text { CDC 2006 } \\
\text { (Table 8-7) } \\
\end{array}$ & Friday et al. 1996 \\
\hline 89 & Ac & $2.50 \mathrm{E}+01$ & $2.50 \mathrm{E}+01$ & & $1.50 \mathrm{E}+01$ & & & \\
\hline 47 & Ag & $5.00 \mathrm{E}+00$ & $2.30 \mathrm{E}+00$ & & $5.00 \mathrm{E}+00$ & & & \\
\hline 13 & $\mathrm{Al}$ & & & $5.00 \mathrm{E}+02$ & $5.00 \mathrm{E}+02$ & & & \\
\hline 95 & $\mathrm{Am}$ & $3.00 \mathrm{E}+01$ & $2.50 \mathrm{E}+02$ & & $3.00 \mathrm{E}+01$ & & $2.40 \mathrm{E}+03$ & $2.45 \mathrm{E}+02$ \\
\hline 33 & As & $1.70 \mathrm{E}+03$ & $1.00 \mathrm{E}+02$ & & $3.00 \mathrm{E}+02$ & & & \\
\hline 85 & At & & & $1.50 \mathrm{E}+01$ & & & & \\
\hline 79 & $\mathrm{Au}$ & $3.30 \mathrm{E}+01$ & & $3.50 \mathrm{E}+01$ & $3.50 \mathrm{E}+01$ & & & \\
\hline 56 & $\mathrm{Ba}$ & $4.00 \mathrm{E}+00$ & $2.00 \mathrm{E}+02$ & & $4.00 \mathrm{E}+00$ & $4.00 \mathrm{E}+00$ & & \\
\hline 4 & $\mathrm{Be}$ & $1.00 \mathrm{E}+02$ & $2.00 \mathrm{E}+00$ & & $1.00 \mathrm{E}+02$ & & & \\
\hline 83 & $\mathrm{Bi}$ & $1.50 \mathrm{E}+01$ & $1.50 \mathrm{E}+01$ & & $1.50 \mathrm{E}+01$ & & & \\
\hline 97 & $\mathrm{Bk}$ & & & $2.50 \mathrm{E}+01$ & & & & \\
\hline 35 & $\mathrm{Br}$ & $4.00 \mathrm{E}+02$ & $4.20 \mathrm{E}+02$ & & $4.20 \mathrm{E}+02$ & $4.20 \mathrm{E}+02$ & & \\
\hline 6 & $\mathrm{C}$ & $5.00 \mathrm{E}+04$ & $4.60 \mathrm{E}+03$ & & $5.00 \mathrm{E}+04$ & $4.60 \mathrm{E}+03$ & & \\
\hline 20 & $\mathrm{Ca}$ & $4.00 \mathrm{E}+01$ & $4.00 \mathrm{E}+01$ & & $1.00 \mathrm{E}+03$ & & & \\
\hline 48 & $\mathrm{Cd}$ & $2.00 \mathrm{E}+02$ & $2.00 \mathrm{E}+02$ & & $2.00 \mathrm{E}+02$ & & & \\
\hline 58 & $\mathrm{Ce}$ & $3.00 \mathrm{E}+01$ & $5.00 \mathrm{E}+02$ & & $3.00 \mathrm{E}+01$ & $1.00 \mathrm{E}+00$ & $3.00 \mathrm{E}+01$ & \\
\hline 98 & $\mathrm{Cf}$ & $2.50 \mathrm{E}+01$ & $2.50 \mathrm{E}+01$ & & $2.50 \mathrm{E}+01$ & & & \\
\hline 17 & $\mathrm{Cl}$ & $5.00 \mathrm{E}+01$ & $5.00 \mathrm{E}+01$ & & $1.00 \mathrm{E}+03$ & & & \\
\hline 96 & $\mathrm{Cm}$ & $3.00 \mathrm{E}+01$ & $2.50 \mathrm{E}+02$ & & $3.00 \mathrm{E}+01$ & & & \\
\hline 27 & Co & $3.00 \mathrm{E}+02$ & $3.30 \mathrm{E}+02$ & & $3.00 \mathrm{E}+02$ & $5.00 \mathrm{E}+01$ & $3.00 \mathrm{E}+02$ & \\
\hline 24 & $\mathrm{Cr}$ & $4.00 \mathrm{E}+00$ & $2.00 \mathrm{E}+02$ & & $2.00 \mathrm{E}+02$ & $2.00 \mathrm{E}+02$ & & \\
\hline 55 & Cs & $2.00 \mathrm{E}+03$ & $2.00 \mathrm{E}+03$ & & $2.00 \mathrm{E}+03$ & $2.00 \mathrm{E}+03$ & $4.70 \mathrm{E}+03$ & \\
\hline 29 & $\mathrm{Cu}$ & $2.00 \mathrm{E}+02$ & $5.00 \mathrm{E}+01$ & & $2.00 \mathrm{E}+02$ & $5.00 \mathrm{E}+01$ & & \\
\hline
\end{tabular}


Table B- 8. Water-to-Fish Bioaccumulation Factors $(\mathrm{L} / \mathrm{kg})$ from Other Sources

\begin{tabular}{|c|c|c|c|c|c|c|c|c|}
\hline $\mathbf{Z}$ & Element & $\begin{array}{c}\text { PNNL-13421 (Staven et al. } \\
\text { 2003) Table } 2.10\end{array}$ & $\begin{array}{c}\text { NUREG CR-5512 } \\
\text { (Kennedy and Strenge } \\
\text { 1992) Table } 6.19 \\
\end{array}$ & $\begin{array}{c}\text { NCRP } 123 \\
\text { Vol I } \\
\text { (NCRP } \\
\text { 1996) Table } \\
5.2 \\
\end{array}$ & $\begin{array}{c}\text { RESRAD } \\
\text { Version } 6 \text { (Yu } \\
\text { et al. } \\
\text { 2001)Table } \\
\text { D.5 } \\
\end{array}$ & $\begin{array}{c}\text { Reg Guide } \\
1.109 \text { (NRC } \\
\text { 1977) Table } \\
\text { A-3 } \\
\end{array}$ & $\begin{array}{r}\text { CDC 2006 } \\
\text { (Table 8-7) } \\
\end{array}$ & Friday et al. 1996 \\
\hline 66 & Dy & $3.00 \mathrm{E}+01$ & & & & & & \\
\hline 68 & $\mathrm{Er}$ & $3.00 \mathrm{E}+01$ & & & & & & \\
\hline 99 & Es & & & $2.50 \mathrm{E}+01$ & & & & \\
\hline 63 & $\mathrm{Eu}$ & $3.00 \mathrm{E}+01$ & $2.50 \mathrm{E}+01$ & & $5.00 \mathrm{E}+01$ & & & \\
\hline 9 & $\mathrm{~F}$ & $1.00 \mathrm{E}+01$ & $1.00 \mathrm{E}+01$ & & $1.00 \mathrm{E}+01$ & & & \\
\hline 26 & $\mathrm{Fe}$ & $2.00 \mathrm{E}+02$ & $2.00 \mathrm{E}+03$ & & $2.00 \mathrm{E}+02$ & $1.00 \mathrm{E}+02$ & & \\
\hline 87 & $\mathrm{Fr}$ & & & $3.00 \mathrm{E}+01$ & & & & \\
\hline 31 & $\mathrm{Ga}$ & $4.00 \mathrm{E}+02$ & & & & & & \\
\hline 64 & Gd & $3.00 \mathrm{E}+01$ & $2.50 \mathrm{E}+01$ & & $2.50 \mathrm{E}+01$ & & & \\
\hline 32 & $\mathrm{Ge}$ & & & $4.00 \mathrm{E}+03$ & $4.00 \mathrm{E}+03$ & & & \\
\hline 2 & $\mathrm{He}$ & $1.00 \mathrm{E}+00$ & $1.00 \mathrm{E}+00$ & & & & & \\
\hline 1 & $\mathrm{H}$ & & & $1.00 \mathrm{E}+00$ & $1.00 \mathrm{E}+00$ & $9.00 \mathrm{E}-01$ & & \\
\hline 72 & Hf & $3.00 \mathrm{E}+02$ & & & & & & \\
\hline 80 & $\mathrm{Hg}$ & $1.00 \mathrm{E}+03$ & $1.00 \mathrm{E}+03$ & & $1.00 \mathrm{E}+03$ & & & \\
\hline 67 & Ho & $3.00 \mathrm{E}+01$ & $2.50 \mathrm{E}+01$ & & $2.50 \mathrm{E}+01$ & & & \\
\hline 53 & $\mathrm{I}$ & $4.00 \mathrm{E}+01$ & $5.00 \mathrm{E}+02$ & & $4.00 \mathrm{E}+01$ & $1.50 \mathrm{E}+01$ & $4.00 \mathrm{E}+01$ & \\
\hline 49 & In & $1.00 \mathrm{E}+04$ & $1.00 \mathrm{E}+05$ & & $1.00 \mathrm{E}+04$ & & & \\
\hline 77 & $\mathrm{Ir}$ & $1.00 \mathrm{E}+01$ & $1.00 \mathrm{E}+01$ & & $1.00 \mathrm{E}+01$ & & & \\
\hline 19 & $\mathrm{~K}$ & $1.00 \mathrm{E}+03$ & $1.00 \mathrm{E}+03$ & $1.00 \mathrm{E}+04$ & $1.00 \mathrm{E}+03$ & & & \\
\hline 57 & $\mathrm{La}$ & $3.00 \mathrm{E}+01$ & $2.50 \mathrm{E}+01$ & & $3.00 \mathrm{E}+01$ & $2.50 \mathrm{E}+01$ & & \\
\hline 71 & $\mathrm{Lu}$ & & & $2.50 \mathrm{E}+01$ & & & & \\
\hline 12 & $\mathrm{Mg}$ & $5.00 \mathrm{E}+01$ & & & & & & \\
\hline 25 & Mn & $4.00 \mathrm{E}+02$ & $4.00 \mathrm{E}+02$ & & $4.00 \mathrm{E}+02$ & $4.00 \mathrm{E}+02$ & & \\
\hline 42 & Mo & $1.00 \mathrm{E}+01$ & $1.00 \mathrm{E}+01$ & & $1.00 \mathrm{E}+01$ & $1.00 \mathrm{E}+01$ & & \\
\hline 7 & $\mathrm{~N}$ & $2.00 \mathrm{E}+05$ & $1.50 \mathrm{E}+05$ & & $1.50 \mathrm{E}+05$ & & & \\
\hline 11 & $\mathrm{Na}$ & $2.00 \mathrm{E}+01$ & $1.00 \mathrm{E}+02$ & & $2.00 \mathrm{E}+01$ & $1.00 \mathrm{E}+02$ & & \\
\hline 41 & $\mathrm{Nb}$ & $3.00 \mathrm{E}+02$ & $2.00 \mathrm{E}+02$ & & $3.00 \mathrm{E}+02$ & $3.00 \mathrm{E}+04$ & $3.00 \mathrm{E}+02$ & \\
\hline
\end{tabular}


Table B- 8. Water-to-Fish Bioaccumulation Factors $(\mathrm{L} / \mathrm{kg})$ from Other Sources

\begin{tabular}{|c|c|c|c|c|c|c|c|c|}
\hline $\mathbf{Z}$ & Element & $\begin{array}{c}\text { PNNL-13421 (Staven et al. } \\
\text { 2003) Table } 2.10\end{array}$ & $\begin{array}{c}\text { NUREG CR-5512 } \\
\text { (Kennedy and Strenge } \\
\text { 1992) Table } 6.19 \\
\end{array}$ & $\begin{array}{c}\text { NCRP } 123 \\
\text { Vol I } \\
\text { (NCRP } \\
\text { 1996) Table } \\
5.2 \\
\end{array}$ & $\begin{array}{c}\text { RESRAD } \\
\text { Version } 6 \text { (Yu } \\
\text { et al. } \\
\text { 2001)Table } \\
\text { D.5 } \\
\end{array}$ & $\begin{array}{c}\text { Reg Guide } \\
1.109 \text { (NRC } \\
\text { 1977) Table } \\
\text { A-3 } \\
\end{array}$ & $\begin{array}{r}\text { CDC 2006 } \\
\text { (Table 8-7) }\end{array}$ & Friday et al. 1996 \\
\hline 60 & $\mathrm{Nd}$ & $3.00 \mathrm{E}+01$ & $2.50 \mathrm{E}+01$ & & $1.00 \mathrm{E}+02$ & $2.50 \mathrm{E}+01$ & & \\
\hline 28 & $\mathrm{Ni}$ & $1.00 \mathrm{E}+02$ & $1.00 \mathrm{E}+02$ & & $1.00 \mathrm{E}+02$ & $1.00 \mathrm{E}+02$ & & \\
\hline 93 & $\mathrm{~Np}$ & $2.10 \mathrm{E}+01$ & $2.50 \mathrm{E}+02$ & & $3.00 \mathrm{E}+01$ & $1.00 \mathrm{E}+01$ & & \\
\hline 8 & $\mathrm{O}$ & $1.00 \mathrm{E}+00$ & & & & & & \\
\hline 76 & Os & $1.00 \mathrm{E}+01$ & $1.00 \mathrm{E}+01$ & & & & & \\
\hline 15 & $\mathrm{P}$ & $5.00 \mathrm{E}+04$ & $7.00 \mathrm{E}+04$ & & $5.00 \mathrm{E}+04$ & $1.00 \mathrm{E}+05$ & $5.00 \mathrm{E}+04$ & \\
\hline 91 & $\mathrm{~Pa}$ & $1.00 \mathrm{E}+01$ & $1.10 \mathrm{E}+01$ & & $1.00 \mathrm{E}+01$ & & & \\
\hline 82 & $\mathrm{~Pb}$ & $3.00 \mathrm{E}+02$ & $1.00 \mathrm{E}+02$ & & $3.00 \mathrm{E}+02$ & & & \\
\hline 46 & $\mathrm{Pd}$ & $1.00 \mathrm{E}+01$ & $1.00 \mathrm{E}+01$ & & $1.00 \mathrm{E}+01$ & & & \\
\hline 61 & $\mathrm{Pm}$ & $3.00 \mathrm{E}+01$ & $2.50 \mathrm{E}+01$ & & $3.00 \mathrm{E}+01$ & & & \\
\hline 84 & Po & $5.00 \mathrm{E}+01$ & $5.00 \mathrm{E}+02$ & & $1.00 \mathrm{E}+02$ & & & \\
\hline 59 & $\operatorname{Pr}$ & $3.00 \mathrm{E}+01$ & $2.50 \mathrm{E}+01$ & & $1.00 \mathrm{E}+02$ & $2.50 \mathrm{E}+01$ & & \\
\hline 78 & $\mathrm{Pt}$ & & & $3.50 \mathrm{E}+01$ & & & & \\
\hline 94 & $\mathrm{Pu}$ & $3.00 \mathrm{E}+01$ & $2.50 \mathrm{E}+02$ & & $3.00 \mathrm{E}+01$ & & $4.70 \mathrm{E}+03$ & $1.40 \mathrm{E}+03$ \\
\hline 88 & $\mathrm{Ra}$ & $5.00 \mathrm{E}+01$ & $7.00 \mathrm{E}+01$ & & $5.00 \mathrm{E}+01$ & & & \\
\hline 37 & $\mathrm{Rb}$ & $2.00 \mathrm{E}+03$ & $2.00 \mathrm{E}+03$ & & $2.00 \mathrm{E}+03$ & $2.00 \mathrm{E}+03$ & & \\
\hline 75 & $\mathrm{Re}$ & $1.20 \mathrm{E}+02$ & $1.20 \mathrm{E}+02$ & $1.20 \mathrm{E}+04$ & & & & \\
\hline 45 & $\mathrm{Rh}$ & $1.00 \mathrm{E}+01$ & $1.00 \mathrm{E}+01$ & & $1.00 \mathrm{E}+01$ & $1.00 \mathrm{E}+01$ & & \\
\hline 45 & $\mathrm{Rn}$ & & & 0 & & & & \\
\hline 44 & $\mathrm{Ru}$ & $1.00 \mathrm{E}+02$ & $1.00 \mathrm{E}+02$ & & $1.00 \mathrm{E}+01$ & $1.00 \mathrm{E}+01$ & $1.00 \mathrm{E}+01$ & \\
\hline 16 & $\mathrm{~S}$ & $8.00 \mathrm{E}+02$ & $7.50 \mathrm{E}+02$ & & $1.00 \mathrm{E}+03$ & & $8.00 \mathrm{E}+02$ & \\
\hline 51 & $\mathrm{Sb}$ & $1.00 \mathrm{E}+02$ & $2.00 \mathrm{E}+02$ & & $1.00 \mathrm{E}+01$ & & & \\
\hline 21 & Sc & $1.00 \mathrm{E}+02$ & $1.00 \mathrm{E}+02$ & & $1.00 \mathrm{E}+02$ & & & \\
\hline 34 & Se & $1.70 \mathrm{E}+02$ & $1.70 \mathrm{E}+02$ & & $2.00 \mathrm{E}+02$ & & & \\
\hline 14 & $\mathrm{Si}$ & $2.00 \mathrm{E}+01$ & & & & & & \\
\hline 62 & $\mathrm{Sm}$ & $3.00 \mathrm{E}+01$ & $2.50 \mathrm{E}+01$ & & $2.50 \mathrm{E}+01$ & & & \\
\hline 50 & Sn & $3.00 \mathrm{E}+03$ & $3.00 \mathrm{E}+03$ & & $3.00 \mathrm{E}+03$ & & & \\
\hline
\end{tabular}


Table B- 8. Water-to-Fish Bioaccumulation Factors $(\mathrm{L} / \mathrm{kg})$ from Other Sources

\begin{tabular}{|c|c|c|c|c|c|c|c|c|}
\hline $\mathbf{Z}$ & Element & $\begin{array}{c}\text { PNNL-13421 (Staven et al. } \\
\text { 2003) Table } 2.10\end{array}$ & $\begin{array}{c}\text { NUREG CR-5512 } \\
\text { (Kennedy and Strenge } \\
\text { 1992) Table } 6.19\end{array}$ & $\begin{array}{c}\text { NCRP } 123 \\
\text { Vol I } \\
\text { (NCRP } \\
\text { 1996) Table } \\
5.2 \\
\end{array}$ & $\begin{array}{c}\text { RESRAD } \\
\text { Version } 6 \text { (Yu } \\
\text { et al. } \\
\text { 2001)Table } \\
\text { D.5 } \\
\end{array}$ & $\begin{array}{c}\text { Reg Guide } \\
1.109 \text { (NRC } \\
\text { 1977) Table } \\
\text { A-3 } \\
\end{array}$ & $\begin{array}{l}\text { CDC 2006 } \\
\text { (Table 8-7) }\end{array}$ & Friday et al. 1996 \\
\hline 38 & $\mathrm{Sr}$ & $6.00 \mathrm{E}+01$ & $5.00 \mathrm{E}+01$ & & $6.00 \mathrm{E}+01$ & $3.00 \mathrm{E}+01$ & $4.50 \mathrm{E}+02$ & $5.01 \mathrm{E}+02$ \\
\hline 73 & Ta & $3.00 \mathrm{E}+02$ & & & $1.00 \mathrm{E}+02$ & & & \\
\hline 65 & $\mathrm{~Tb}$ & $3.00 \mathrm{E}+01$ & $2.50 \mathrm{E}+01$ & & $2.50 \mathrm{E}+01$ & & & \\
\hline 43 & Tc & $2.00 \mathrm{E}+01$ & $1.50 \mathrm{E}+01$ & & $2.00 \mathrm{E}+01$ & $1.50 \mathrm{E}+01$ & $2.00 \mathrm{E}+01$ & \\
\hline 52 & $\mathrm{Te}$ & $4.00 \mathrm{E}+02$ & $4.00 \mathrm{E}+02$ & & $4.00 \mathrm{E}+02$ & $4.00 \mathrm{E}+02$ & & \\
\hline 90 & Th & $1.00 \mathrm{E}+02$ & $1.00 \mathrm{E}+02$ & & $1.00 \mathrm{E}+02$ & & $1.00 \mathrm{E}+02$ & \\
\hline 22 & $\mathrm{Ti}$ & & & $1.00 \mathrm{E}+03$ & & & & \\
\hline 81 & $\mathrm{Tl}$ & $1.00 \mathrm{E}+04$ & & & $1.00 \mathrm{E}+04$ & & & \\
\hline 92 & $\mathrm{U}$ & $1.00 \mathrm{E}+01$ & $5.00 \mathrm{E}+01$ & & $1.00 \mathrm{E}+01$ & & $1.00 \mathrm{E}+01$ & \\
\hline 23 & $\mathrm{~V}$ & & & $2.00 \mathrm{E}+02$ & & & & \\
\hline 74 & $\mathrm{~W}$ & $1.00 \mathrm{E}+01$ & $1.20 \mathrm{E}+03$ & & $1.20 \mathrm{E}+03$ & $1.20 \mathrm{E}+03$ & & \\
\hline 39 & $\mathrm{Y}$ & $3.00 \mathrm{E}+01$ & $2.50 \mathrm{E}+01$ & & $3.00 \mathrm{E}+01$ & $2.50 \mathrm{E}+01$ & $3.00 \mathrm{E}+01$ & \\
\hline 30 & $\mathrm{Zn}$ & $3.50 \mathrm{E}+02$ & $2.50 \mathrm{E}+03$ & & $1.00 \mathrm{E}+03$ & $2.00 \mathrm{E}+03$ & $1.00 \mathrm{E}+03$ & \\
\hline 40 & $\mathrm{Zr}$ & $3.00 \mathrm{E}+02$ & $2.00 \mathrm{E}+02$ & & $3.00 \mathrm{E}+02$ & $3.30 \mathrm{E}+00$ & $3.00 \mathrm{E}+02$ & \\
\hline
\end{tabular}


Table B- 9. Bioaccumulation Factors from Other DOE Facilities

\begin{tabular}{|c|c|c|c|c|c|c|c|c|c|c|c|c|}
\hline \multirow[b]{2}{*}{$\mathbf{Z}$} & \multirow[b]{2}{*}{ Element } & \multicolumn{4}{|c|}{ Soil-to-Vegetable } & \multicolumn{3}{|c|}{ Milk (d/L) } & \multicolumn{3}{|c|}{ Meat (d/kg) } & \multirow{2}{*}{$\begin{array}{c}\text { Fish }(\mathrm{L} / \mathrm{kg}) \\
\text { Hanford }\end{array}$} \\
\hline & & Idaho & Hanford & ORNL & NTS & Idaho & Hanford & NTS & Idaho & Hanford & NTS & \\
\hline 89 & Ac & $2.50 \mathrm{E}-03$ & 3.50E-03 & 1.50E-04 & 3.50E-04 & $2.0 \mathrm{E}-05$ & $2.0 \mathrm{E}-05$ & $2.0 \mathrm{E}-05$ & $2.00 \mathrm{E}-05$ & $2.50 \mathrm{E}-05$ & $2.50 \mathrm{E}-05$ & $2.5 \mathrm{E}+01$ \\
\hline 47 & Ag & $1.50 \mathrm{E}-01$ & $1.30 \mathrm{E}-03$ & & & $2.5 \mathrm{E}-02$ & $5.0 \mathrm{E}-05$ & & $3.00 \mathrm{E}-03$ & $3.00 \mathrm{E}-03$ & & $5.0 \mathrm{E}+00$ \\
\hline 13 & $\mathrm{Al}$ & & $6.50 \mathrm{E}-04$ & 2.80E-04 & 4.00E-03 & & $2.0 \mathrm{E}-04$ & $2.0 \mathrm{E}-04$ & & $1.50 \mathrm{E}-03$ & 5.00E-04 & $5.0 \mathrm{E}+02$ \\
\hline 95 & $\mathrm{Am}$ & $1.00 \mathrm{E}-03$ & 4.30E-04 & 1.10E-04 & 4.10E-04 & $2.0 \mathrm{E}-06$ & $1.5 \mathrm{E}-06$ & $4.0 \mathrm{E}-07$ & $5.00 \mathrm{E}-05$ & 4.00E-05 & 3.50E-06 & $2.1 \mathrm{E}+01$ \\
\hline 33 & As & & $6.00 \mathrm{E}-03$ & & & & $6.0 \mathrm{E}-05$ & & & $2.00 \mathrm{E}-03$ & & $2.4 \mathrm{E}+02$ \\
\hline 85 & At & $2.00 \mathrm{E}-01$ & & & & $1.0 \mathrm{E}-02$ & & & $1.00 \mathrm{E}-02$ & & & \\
\hline 5 & $\mathrm{~B}$ & & $4.00 \mathrm{E}+00$ & & & & $1.5 \mathrm{E}-03$ & & & 8.00E-04 & & \\
\hline 56 & $\mathrm{Ba}$ & $4.00 \mathrm{E}-02$ & $3.00 \mathrm{E}-02$ & & $1.50 \mathrm{E}-02$ & $8.0 \mathrm{E}-03$ & $4.8 \mathrm{E}-04$ & $3.5 \mathrm{E}-04$ & $3.00 \mathrm{E}-02$ & $2.00 \mathrm{E}-04$ & $1.50 \mathrm{E}-04$ & $4.0 \mathrm{E}+00$ \\
\hline 4 & $\mathrm{Be}$ & $4.00 \mathrm{E}-03$ & $1.50 \mathrm{E}-03$ & $6.50 \mathrm{E}-04$ & $1.50 \mathrm{E}-03$ & $2.0 \mathrm{E}-06$ & $9.0 \mathrm{E}-07$ & $9.0 \mathrm{E}-07$ & $1.00 \mathrm{E}-03$ & $1.00 \mathrm{E}-03$ & $1.00 \mathrm{E}-03$ & $1.0 \mathrm{E}+02$ \\
\hline 83 & $\mathrm{Bi}$ & $1.00 \mathrm{E}-01$ & 5.00E-03 & $2.20 \mathrm{E}-03$ & $5.00 \mathrm{E}-03$ & $5.0 \mathrm{E}-04$ & $5.0 \mathrm{E}-04$ & $5.0 \mathrm{E}-04$ & $2.00 \mathrm{E}-03$ & $4.00 \mathrm{E}-04$ & $4.00 \mathrm{E}-04$ & $1.0 \mathrm{E}+01$ \\
\hline 97 & $\mathrm{Bk}$ & & 4.10E-04 & & & & 1.5E-06 & & & 4.00E-05 & & $2.5 \mathrm{E}+01$ \\
\hline 6 & $\mathrm{C}$ & $5.50 \mathrm{E}+00$ & 7.00E-01 & 5.60E-01 & 7.00E-01 & $1.2 \mathrm{E}-02$ & $1.1 \mathrm{E}-02$ & & $3.10 \mathrm{E}-02$ & $4.89 \mathrm{E}-02$ & & $5.0 \mathrm{E}+04$ \\
\hline 20 & $\mathrm{Ca}$ & & 3.50E-01 & 1.50E-01 & 3.50E-01 & & $3.0 \mathrm{E}-03$ & $1.0 \mathrm{E}-02$ & & $2.00 \mathrm{E}-03$ & $7.00 \mathrm{E}-04$ & $4.0 \mathrm{E}+01$ \\
\hline 48 & $\mathrm{Cd}$ & $3.00 \mathrm{E}-01$ & $1.50 \mathrm{E}-01$ & 6.50E-02 & $1.50 \mathrm{E}-01$ & $1.0 \mathrm{E}-03$ & $1.0 \mathrm{E}-03$ & $1.0 \mathrm{E}-03$ & $4.00 \mathrm{E}-04$ & $4.00 \mathrm{E}-04$ & $5.50 \mathrm{E}-04$ & $2.0 \mathrm{E}+02$ \\
\hline 58 & $\mathrm{Ce}$ & & 3.00E-02 & & & & $3.0 \mathrm{E}-05$ & & & $2.00 \mathrm{E}-05$ & & $3.0 \mathrm{E}+01$ \\
\hline 98 & $\mathrm{Cf}$ & $1.00 \mathrm{E}-03$ & $1.00 \mathrm{E}-02$ & $6.50 \mathrm{E}-06$ & & $7.5 \mathrm{E}-07$ & $7.5 \mathrm{E}-07$ & & $6.00 \mathrm{E}-05$ & $5.00 \mathrm{E}-03$ & & $2.5 \mathrm{E}+01$ \\
\hline 17 & $\mathrm{Cl}$ & & $7.00 \mathrm{E}+01$ & 3.00E-01 & $7.00 \mathrm{E}+01$ & & 1.7E-02 & 1.5E-02 & & 2.00E-02 & 8.00E-02 & $5.0 \mathrm{E}+01$ \\
\hline 96 & $\mathrm{Cm}$ & $1.00 \mathrm{E}-03$ & 4.60E-04 & 6.50E-06 & $2.40 \mathrm{E}-04$ & $2.0 \mathrm{E}-06$ & $2.0 \mathrm{E}-05$ & $2.0 \mathrm{E}-05$ & $2.00 \mathrm{E}-05$ & $3.50 \mathrm{E}-06$ & $3.50 \mathrm{E}-06$ & $2.1 \mathrm{E}+01$ \\
\hline 27 & Co & $8.00 \mathrm{E}-02$ & 6.80E-02 & 3.00E-03 & 4.00E-02 & 2.0E-03 & $3.0 \mathrm{E}-04$ & $2.0 \mathrm{E}-03$ & $2.00 \mathrm{E}-02$ & $1.00 \mathrm{E}-02$ & 2.00E-02 & $3.0 \mathrm{E}+02$ \\
\hline 55 & Cs & $4.00 \mathrm{E}-02$ & 1.30E-01 & 1.30E-02 & 4.90E-02 & $8.0 \mathrm{E}-03$ & 7.9E-03 & $7.0 \mathrm{E}-03$ & $3.00 \mathrm{E}-02$ & $5.00 \mathrm{E}-02$ & $2.00 \mathrm{E}-02$ & $2.0 \mathrm{E}+03$ \\
\hline 63 & $\mathrm{Eu}$ & $2.50 \mathrm{E}-03$ & 4.00E-03 & $1.70 \mathrm{E}-03$ & 4.00E-03 & $2.0 \mathrm{E}-05$ & $2.0 \mathrm{E}-05$ & $2.0 \mathrm{E}-05$ & $2.00 \mathrm{E}-03$ & $5.00 \mathrm{E}-03$ & $5.00 \mathrm{E}-03$ & $5.0 \mathrm{E}+01$ \\
\hline 9 & $\mathrm{~F}$ & & 6.00E-03 & & & & $1.0 \mathrm{E}-03$ & & & $1.50 \mathrm{E}-01$ & & $1.0 \mathrm{E}+01$ \\
\hline 26 & $\mathrm{Fe}$ & & 4.00E-03 & & & & $3.0 \mathrm{E}-05$ & & & $2.00 \mathrm{E}-02$ & & $2.0 \mathrm{E}+02$ \\
\hline 87 & $\mathrm{Fr}$ & $3.00 \mathrm{E}-02$ & & & & 8.0E-03 & & & $3.00 \mathrm{E}-02$ & & & \\
\hline 64 & Gd & $2.50 \mathrm{E}-03$ & 4.00E-03 & & 4.00E-03 & $2.0 \mathrm{E}-05$ & $2.0 \mathrm{E}-05$ & $2.0 \mathrm{E}-05$ & $2.00 \mathrm{E}-03$ & $3.50 \mathrm{E}-03$ & 3.50E-03 & $2.5 \mathrm{E}+01$ \\
\hline 1 & $\mathrm{H}$ & $4.80 \mathrm{E}+00$ & 0 & $4.80 \mathrm{E}+00$ & $6.92 \mathrm{E}+00$ & $1.0 \mathrm{E}-02$ & 0 & & $1.20 \mathrm{E}-02$ & 0 & & $1.0 \mathrm{E}+00$ \\
\hline 80 & $\mathrm{Hg}$ & & $2.00 \mathrm{E}-01$ & & & & 4.7E-04 & & & $2.50 \mathrm{E}-01$ & & $1.0 \mathrm{E}+03$ \\
\hline 67 & Ho & $2.60 \mathrm{E}-03$ & 4.00E-03 & & $4.00 \mathrm{E}-03$ & 2.0E-05 & $2.0 \mathrm{E}-05$ & $2.0 \mathrm{E}-05$ & $2.00 \mathrm{E}-03$ & $4.50 \mathrm{E}-03$ & 4.50E-03 & $2.5 \mathrm{E}+01$ \\
\hline 53 & $\mathrm{I}$ & $2.00 \mathrm{E}-02$ & 2.00E-02 & 2.20E-02 & 5.00E-02 & $1.0 \mathrm{E}-02$ & $1.2 \mathrm{E}-02$ & $1.0 \mathrm{E}-02$ & 7.00E-03 & 4.00E-02 & 7.00E-03 & $4.0 \mathrm{E}+01$ \\
\hline
\end{tabular}


Table B- 9. Bioaccumulation Factors from Other DOE Facilities (continued)

\begin{tabular}{|c|c|c|c|c|c|c|c|c|c|c|c|c|}
\hline \multirow[b]{2}{*}{$\mathbf{Z}$} & \multirow[b]{2}{*}{ Element } & \multicolumn{4}{|c|}{ Soil-to-Vegetable } & \multicolumn{3}{|c|}{ Milk (d/L) } & \multicolumn{3}{|c|}{ Meat (d/kg) } & \multirow{2}{*}{$\begin{array}{c}\text { Fish }(\mathrm{L} / \mathrm{kg}) \\
\text { Hanford } \\
\end{array}$} \\
\hline & & Idaho & Hanford & ORNL & NTS & Idaho & Hanford & NTS & Idaho & Hanford & NTS & \\
\hline 49 & In & $3.00 \mathrm{E}-03$ & $4.00 \mathrm{E}-04$ & & & $2.0 \mathrm{E}-04$ & $1.0 \mathrm{E}-04$ & & $4.00 \mathrm{E}-03$ & 8.00E-03 & & $1.0 \mathrm{E}+05$ \\
\hline 19 & $\mathrm{~K}$ & & $5.50 \mathrm{E}-01$ & $2.40 \mathrm{E}-01$ & 5.50E-01 & & 7.2E-03 & $7.0 \mathrm{E}-03$ & & $2.00 \mathrm{E}-02$ & $2.00 \mathrm{E}-02$ & $1.0 \mathrm{E}+03$ \\
\hline 57 & $\mathrm{La}$ & $2.50 \mathrm{E}-03$ & & & & $2.0 \mathrm{E}-05$ & & & $2.00 \mathrm{E}-03$ & & & \\
\hline 25 & $\mathrm{Mn}$ & & $2.80 \mathrm{E}-01$ & & & & $3.0 \mathrm{E}-05$ & & & $5.00 \mathrm{E}-04$ & & $4.0 \mathrm{E}+02$ \\
\hline 42 & Mo & & $8.00 \mathrm{E}-01$ & & & & $1.7 \mathrm{E}-03$ & & & $1.00 \mathrm{E}-03$ & & $1.0 \mathrm{E}+01$ \\
\hline 11 & $\mathrm{Na}$ & & $3.00 \mathrm{E}-01$ & & & & $1.6 \mathrm{E}-02$ & & & 8.00E-02 & & $8.0 \mathrm{E}+00$ \\
\hline 41 & $\mathrm{Nb}$ & $1.00 \mathrm{E}-02$ & $1.70 \mathrm{E}-02$ & $2.20 \mathrm{E}-03$ & 5.00E-03 & $2.0 \mathrm{E}-06$ & $4.1 \mathrm{E}-07$ & $2.0 \mathrm{E}-02$ & $3.00 \mathrm{E}-07$ & $3.00 \mathrm{E}-07$ & $2.50 \mathrm{E}-01$ & $3.0 \mathrm{E}+02$ \\
\hline 28 & $\mathrm{Ni}$ & $5.00 \mathrm{E}-02$ & $6.00 \mathrm{E}-02$ & $2.60 \mathrm{E}-02$ & $6.00 \mathrm{E}-02$ & $2.0 \mathrm{E}-02$ & $1.6 \mathrm{E}-02$ & $1.0 \mathrm{E}-03$ & $5.00 \mathrm{E}-03$ & $5.00 \mathrm{E}-03$ & $6.00 \mathrm{E}-03$ & $1.0 \mathrm{E}+02$ \\
\hline 93 & $\mathrm{~Np}$ & $2.00 \mathrm{E}-02$ & $1.40 \mathrm{E}-02$ & $4.30 \mathrm{E}-03$ & 9.40E-03 & $5.0 \mathrm{E}-06$ & $5.0 \mathrm{E}-06$ & $5.0 \mathrm{E}-06$ & $1.00 \mathrm{E}-03$ & $1.00 \mathrm{E}-03$ & $5.50 \mathrm{E}-05$ & $2.1 \mathrm{E}+01$ \\
\hline 15 & $\mathrm{P}$ & & $3.50 \mathrm{E}+00$ & & & & $1.6 \mathrm{E}-02$ & & & $5.00 \mathrm{E}-02$ & & $1.5 \mathrm{E}+03$ \\
\hline 91 & $\mathrm{~Pa}$ & $1.00 \mathrm{E}-02$ & $2.50 \mathrm{E}-04$ & $1.10 \mathrm{E}-04$ & $2.50 \mathrm{E}-04$ & $5.0 \mathrm{E}-06$ & $5.0 \mathrm{E}-06$ & $5.0 \mathrm{E}-06$ & $5.00 \mathrm{E}-03$ & $1.00 \mathrm{E}-05$ & $1.00 \mathrm{E}-05$ & $1.0 \mathrm{E}+01$ \\
\hline 82 & $\mathrm{~Pb}$ & 1.00E-02 & $6.20 \mathrm{E}-03$ & $3.90 \mathrm{E}-03$ & $3.20 \mathrm{E}-03$ & 3.0E-04 & $2.5 \mathrm{E}-04$ & $2.5 \mathrm{E}-04$ & $8.00 \mathrm{E}-04$ & $4.00 \mathrm{E}-04$ & $3.00 \mathrm{E}-04$ & $3.0 \mathrm{E}+02$ \\
\hline 46 & $\mathrm{Pd}$ & $1.00 \mathrm{E}-01$ & $4.00 \mathrm{E}-02$ & $1.70 \mathrm{E}-02$ & 4.00E-02 & $5.0 \mathrm{E}-03$ & $1.0 \mathrm{E}-02$ & $1.0 \mathrm{E}-02$ & $1.00 \mathrm{E}-03$ & $4.00 \mathrm{E}-03$ & $4.00 \mathrm{E}-03$ & $1.0 \mathrm{E}+01$ \\
\hline 61 & $\mathrm{Pm}$ & $2.50 \mathrm{E}-03$ & $4.00 \mathrm{E}-03$ & & & $2.0 \mathrm{E}-05$ & $2.0 \mathrm{E}-05$ & & $2.00 \mathrm{E}-03$ & 5.00E-03 & & $3.0 \mathrm{E}+01$ \\
\hline 84 & Po & $1.00 \mathrm{E}-03$ & 7.00E-03 & $1.70 \mathrm{E}-04$ & & $3.4 \mathrm{E}-04$ & 3.4E-04 & & $5.00 \mathrm{E}-03$ & $5.00 \mathrm{E}-03$ & & $5.0 \mathrm{E}+01$ \\
\hline 94 & $\mathrm{Pu}$ & $1.00 \mathrm{E}-03$ & $6.00 \mathrm{E}-05$ & $1.90 \mathrm{E}-05$ & $2.00 \mathrm{E}-04$ & $1.0 \mathrm{E}-06$ & $1.1 \mathrm{E}-06$ & $1.0 \mathrm{E}-07$ & $1.00 \mathrm{E}-04$ & $1.00 \mathrm{E}-05$ & $5.00 \mathrm{E}-07$ & $2.1 \mathrm{E}+01$ \\
\hline 88 & $\mathrm{Ra}$ & 4.00E-02 & 2.50E-03 & $6.50 \mathrm{E}-04$ & 3.20E-03 & $1.0 \mathrm{E}-03$ & 1.3E-03 & 4.5E-04 & $1.00 \mathrm{E}-03$ & $9.00 \mathrm{E}-04$ & $2.50 \mathrm{E}-04$ & $5.0 \mathrm{E}+01$ \\
\hline 37 & $\mathrm{Rb}$ & $1.30 \mathrm{E}-01$ & $9.00 \mathrm{E}-01$ & $3.00 \mathrm{E}-02$ & $7.00 \mathrm{E}-02$ & $1.0 \mathrm{E}-02$ & $1.2 \mathrm{E}-02$ & $1.0 \mathrm{E}-02$ & $1.50 \mathrm{E}-02$ & $1.00 \mathrm{E}-02$ & $1.50 \mathrm{E}-02$ & $2.0 \mathrm{E}+03$ \\
\hline 75 & $\mathrm{Re}$ & & $3.50 \mathrm{E}-01$ & & & & $1.5 \mathrm{E}-03$ & & & $8.00 \mathrm{E}-03$ & & $1.2 \mathrm{E}+02$ \\
\hline 86 & $\mathrm{Rn}$ & 0 & & & & 0 & & & 0 & & & \\
\hline 44 & $\mathrm{Ru}$ & & $4.00 \mathrm{E}-02$ & & & & 3.3E-06 & & & $5.00 \mathrm{E}-02$ & & $1.0 \mathrm{E}+01$ \\
\hline 51 & $\mathrm{Sb}$ & $1.00 \mathrm{E}-02$ & 5.60E-04 & $1.30 \mathrm{E}-02$ & & & $2.5 \mathrm{E}-05$ & & $1.00 \mathrm{E}-03$ & $4.00 \mathrm{E}-05$ & & $1.0 \mathrm{E}+02$ \\
\hline 34 & Se & $1.00 \mathrm{E}-01$ & $2.50 \mathrm{E}-01$ & $1.10 \mathrm{E}-02$ & $2.50 \mathrm{E}-02$ & $1.0 \mathrm{E}-02$ & $4.0 \mathrm{E}-03$ & $4.0 \mathrm{E}-03$ & $1.00 \mathrm{E}-01$ & $1.50 \mathrm{E}-02$ & $1.50 \mathrm{E}-02$ & $1.7 \mathrm{E}+02$ \\
\hline 14 & $\mathrm{Si}$ & & 7.00E-02 & & & & $2.0 \mathrm{E}-05$ & & & 4.00E-05 & & $2.0 \mathrm{E}+01$ \\
\hline 62 & $\mathrm{Sm}$ & $2.50 \mathrm{E}-03$ & $4.00 \mathrm{E}-03$ & $1.70 \mathrm{E}-03$ & 4.00E-03 & $2.0 \mathrm{E}-05$ & $2.0 \mathrm{E}-05$ & $2.0 \mathrm{E}-05$ & $2.00 \mathrm{E}-03$ & $5.00 \mathrm{E}-03$ & $5.00 \mathrm{E}-03$ & $2.5 \mathrm{E}+01$ \\
\hline 50 & Sn & $2.50 \mathrm{E}-03$ & $6.00 \mathrm{E}-03$ & $2.60 \mathrm{E}-03$ & $6.00 \mathrm{E}-03$ & $1.0 \mathrm{E}-03$ & $1.0 \mathrm{E}-03$ & $1.0 \mathrm{E}-03$ & 1.00E-02 & $8.00 \mathrm{E}-02$ & $8.00 \mathrm{E}-02$ & $3.0 \mathrm{E}+03$ \\
\hline 38 & $\mathrm{Sr}$ & 3.00E-01 & $6.10 \mathrm{E}-01$ & $1.10 \mathrm{E}-01$ & 8.10E-01 & $2.0 \mathrm{E}-03$ & $2.8 \mathrm{E}-03$ & $1.5 \mathrm{E}-03$ & 8.00E-03 & 8.00E-03 & $3.00 \mathrm{E}-04$ & $6.0 \mathrm{E}+01$ \\
\hline 43 & Tc & $5.00 \mathrm{E}+00$ & 7.70E-01 & $6.50 \mathrm{E}-01$ & $1.10 \mathrm{E}+00$ & $1.0 \mathrm{E}-03$ & $1.4 \mathrm{E}-04$ & $1.0 \mathrm{E}-02$ & $1.00 \mathrm{E}-04$ & $1.00 \mathrm{E}-04$ & 8.50E-03 & $2.0 \mathrm{E}+01$ \\
\hline 52 & Te & 6.00E-01 & 4.00E-03 & & & $5.0 \mathrm{E}-04$ & 4.5E-04 & & 7.00E-03 & 7.00E-03 & & $4.0 \mathrm{E}+02$ \\
\hline 90 & Th & $1.00 \mathrm{E}-03$ & $2.50 \mathrm{E}-04$ & $3.70 \mathrm{E}-05$ & $1.20 \mathrm{E}-04$ & $5.0 \mathrm{E}-06$ & $5.0 \mathrm{E}-06$ & $5.0 \mathrm{E}-06$ & $1.00 \mathrm{E}-04$ & $6.00 \mathrm{E}-06$ & $6.00 \mathrm{E}-06$ & $1.0 \mathrm{E}+02$ \\
\hline 22 & $\mathrm{Ti}$ & & $3.00 \mathrm{E}-03$ & & & & $1.0 \mathrm{E}-02$ & & & $3.00 \mathrm{E}-02$ & & $1.0 \mathrm{E}+03$ \\
\hline
\end{tabular}


Table B- 9. Bioaccumulation Factors from Other DOE Facilities (continued)

\begin{tabular}{|c|c|c|c|c|c|c|c|c|c|c|c|c|}
\hline \multirow[b]{2}{*}{$\mathbf{Z}$} & \multirow[b]{2}{*}{ Element } & \multicolumn{4}{|c|}{ Soil-to-Vegetable } & \multicolumn{3}{|c|}{ Milk (d/L) } & \multicolumn{3}{|c|}{ Meat (d/kg) } & \multirow{2}{*}{$\begin{array}{c}\text { Fish }(\mathrm{L} / \mathrm{kg}) \\
\text { Hanford } \\
\end{array}$} \\
\hline & & Idaho & Hanford & ORNL & NTS & Idaho & Hanford & NTS & Idaho & Hanford & NTS & \\
\hline 81 & $\mathrm{Tl}$ & $2.00 \mathrm{E}-01$ & $4.00 \mathrm{E}-04$ & & & $3.0 \mathrm{E}-03$ & $2.0 \mathrm{E}-03$ & & $2.00 \mathrm{E}-03$ & 4.00E-02 & & $1.0 \mathrm{E}+04$ \\
\hline 92 & $\mathrm{U}$ & $2.50 \mathrm{E}-03$ & $1.20 \mathrm{E}-02$ & $1.70 \mathrm{E}-03$ & $1.40 \mathrm{E}-02$ & $6.0 \mathrm{E}-04$ & $4.0 \mathrm{E}-04$ & $6.0 \mathrm{E}-04$ & $3.40 \mathrm{E}-04$ & $3.00 \mathrm{E}-04$ & $2.00 \mathrm{E}-04$ & $1.0 \mathrm{E}+01$ \\
\hline 23 & $\mathrm{~V}$ & & 3.00E-03 & & & & $2.0 \mathrm{E}-05$ & & & $2.50 \mathrm{E}-03$ & & $2.0 \mathrm{E}+02$ \\
\hline 39 & $\mathrm{Y}$ & 3.00E-01 & $1.00 \mathrm{E}-02$ & $2.60 \mathrm{E}-03$ & & $2.0 \mathrm{E}-03$ & $2.0 \mathrm{E}-05$ & & 8.00E-03 & $1.00 \mathrm{E}-03$ & & $3.0 \mathrm{E}+01$ \\
\hline 40 & $\mathrm{Zr}$ & $1.00 \mathrm{E}-03$ & 1.00E-03 & 2.20E-04 & $5.00 \mathrm{E}-04$ & $6.0 \mathrm{E}-07$ & $5.5 \mathrm{E}-07$ & 3.0E-05 & $1.00 \mathrm{E}-06$ & $1.00 \mathrm{E}-06$ & 5.50E-03 & $3.0 \mathrm{E}+02$ \\
\hline
\end{tabular}




Baseline Parameter Update For Human Health Input And Transfer Factors For Radiological Performance Assessments At The Savannah River Site

\section{DISTRIBUTION (23)}

Sherri R. Ross, 704-S

Steven A, Thomas, 766-H

Thomas C. Robinson, Jr., 766-H

Kent H. Rosenberger, 766-H

Timothy W. Coffield, 766-H

Mark H. Layton, 766-H

Marcia B. Birk, 766-H

Jeffrey L. Newman, 766-H

William E. Stevens, 773-A

Elmer L. Wilhite, 773-43A

John B. Gladden, 773-42A

Eduardo B. Farfan, 999-W

G. Timothy Jannik, 773-42A

Patricia L. Lee, 773-42A

SRNL Records (4), 773-52A

EDG Records (5), 773-42A 